\title{
INVESTIGAÇÃO DO DESGASTE DE FERRAMENTAS DE PCBN E METAL DURO NO FRESAMENTO DE TOPO DE AÇOS ENDURECIDOS
}

Aldo Braghini Junior

Dissertação apresentada à Escola de Engenharia de São Carlos, da Universidade de São Paulo, como parte dos requisitos para obtenção do título de Mestre em Engenharia Mecânica.

ORIENTADOR: Prof. Dr. Reginaldo Teixeira Coelho

São Carlos

1998 
Aos meus pais,

Aldo e Janete 


\section{Agradecimentos}

Ao professor Reginaldo Teixeira Coelho pela orientação, amizade e confiança;

Aos professores João Fernando Gomes de Oliveira, Benedito Di Giácomo e Luiz Carlos Casteletti pela grande ajuda na elaboração deste trabalho;

À Bianca pela sua amizade e compreensão diante da ausência e das dificuldades;

Aos amigos do Grupo de Otimização de Processos de Fabricação Juarez, Nelson, João Jorge, Carlos e Ronaldo;

Às empresas Sensis - São Carlos, pelo aparelho de Emissão Acústica BM12. Nixon Industrial Diamonds (Coventry - Inglaterra) e Difer Diamantes Industriais Ltda. (São Paulo - Brasil), pelas ferramentas de PCBN e à De Beers do Brasil (São Paulo - Brasil), pelos "blanks" de PCBN.

Aos técnicos Bruno, Botelho, Sr. Adão, José Carlos (LAMAFE); Adolfo e Agno (Oficina Mecânica); "Tico" (Departamento de Materiais) pela atenção e ajuda;

Às secretárias da pós-graduação Ana Paula e Elizabeth e aos demais funcionários da secretaria da Engenharia Mecânica pela atenção;

À Capes, pela bolsa concedida. 


\section{SUMÁRIO}

SUMÁRIO....................................................................................................................................................................I

LISTA DE FIGURAS........................................................................................................................................................................ III

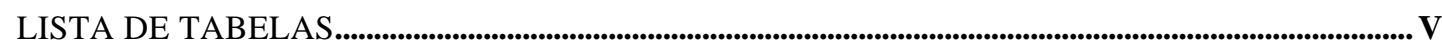

LISTA DE ABREVIATURAS E SIGLAS............................................................................................................................VI

LISTA DE SÍMBOLOS .............................................................................................................................................................VII

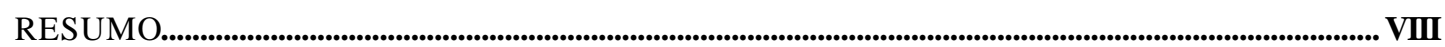

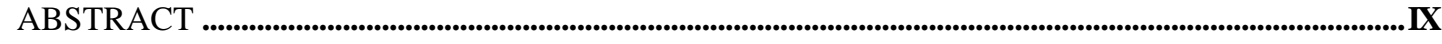

1.0 - INTRODUÇÃO..............................................................................................................................................................1

1.1 - OBJETIVOS

1.2 - ESTRUTURA DO TRABALHO ..................................................................................................

2.0 - REVISÃO BIBLIOGRÁFICA .................................................................................................................5

2.1 - O PROCESSO DE CORTE DOS METAIS - GENERALIDADES............................................................ 6

2.1.1 - Mecanismo de formação de cavacos no corte ortogonal ..............................................

2.1.2 - Formação e quebra de cavacos ...............................................................................12

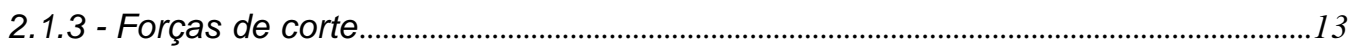

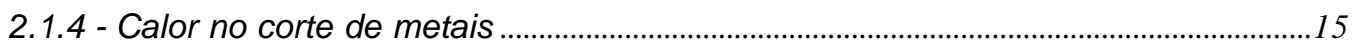

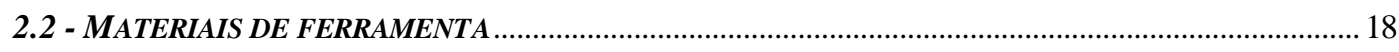

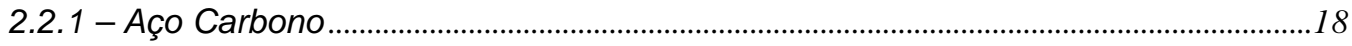

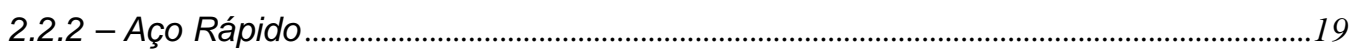

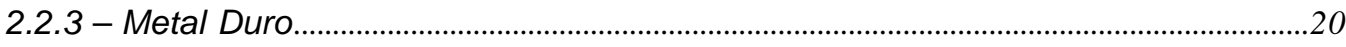

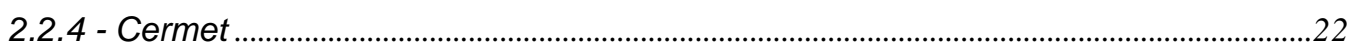

2.2 .5 - Cerâmica

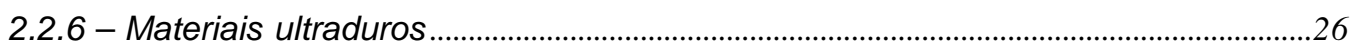

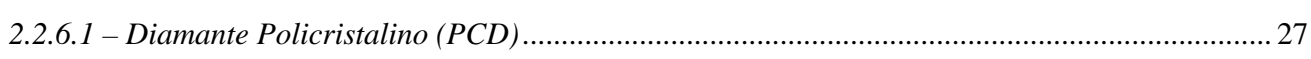

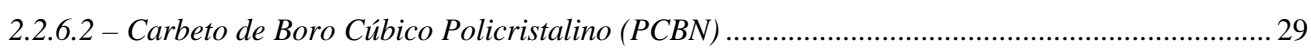

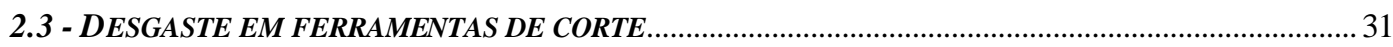

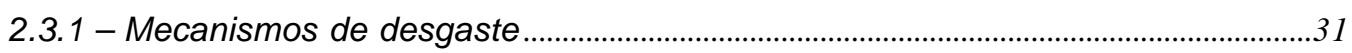

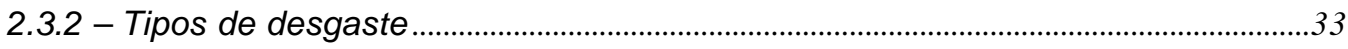

2.3.3 - Exemplos de associações entre tipos e mecanismos de desgaste..........................38

2.4 - EMISSÃO ACÚSTICA NA USINAGEM DOS METAIS....................................................................... 41 
3.0 - TRABALHO EXPERIMENTAL_................................................................................................................47

3.1 - EQUIPAMENTOS

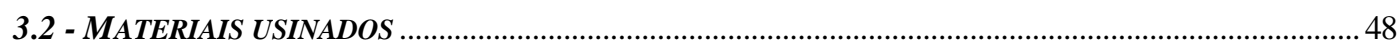

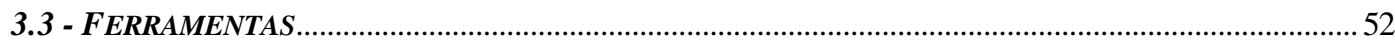

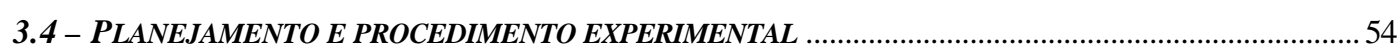

3.4.1 - Montagem do banco de ensaios...............................................................................5

3.4.2 - Planejamento dos experimentos ....................................................................................5

3.4.3 - Montagem do sensor de emissão acústica e medição do sinal ...............................57

3.4.4 - Usinagem dos blocos .......................................................................................................

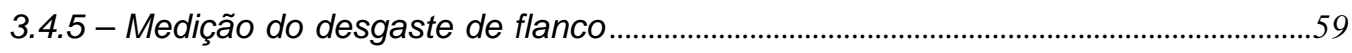

3.4.6 - Medição da Rugosidade ..........................................................................................60

3.4.7 - Preparação das amostras para análise de microestrura dos aços usinados ....60

3.4.8 - Preparação das amostras para análise em microscópio eletrônico de varredura (SEM)

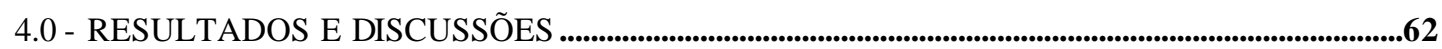

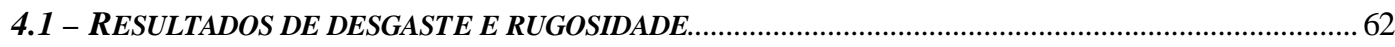

4.1.1 - Influência do material usinado no desgaste das ferramentas..................................62

4.1.2 - Influência da velocidade de corte no desgaste das ferramentas ............................66

4.1.3 - Influência do avanço e da velocidade de corte no desgaste do aço H13............69

4.1.4 - Resumo dos resultados sobre medição de desgaste e rugosidade superficial.70

4.2 - ANÁLISE DE DESGASTE DAS FERRAMENTAS............................................................................... 72

4.2.1 - Apresentação e descrição das ferramentas desgastadas........................................72

4.2.2 - Resumo sobre a análise de desgaste .........................................................................81

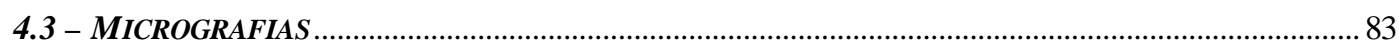

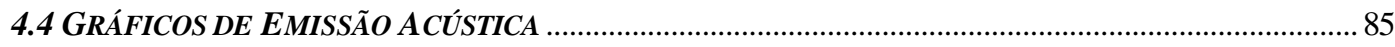

4.4.1 - Influência da velocidade de corte sobre a emissão acústica....................................85

4.4.2 - Influência do material da peça sobre a emissão acústica.........................................87

4.4.3 - Influência do material da ferramenta sobre a emissão acústica..............................88

4.4.4 - Resumo dos gráficos de emissão acústica.................................................................90

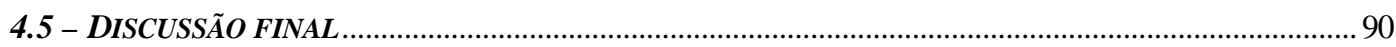

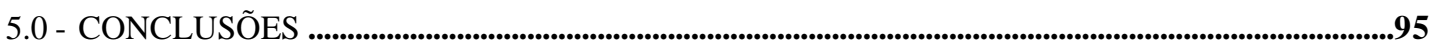

6.0 - SUGESTÕES PARA TRABALHOS FUTUROS ........................................................................................96

7.0 - BIBLIOGRAFIA ……...................................................................................................................................97

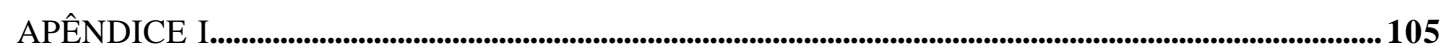

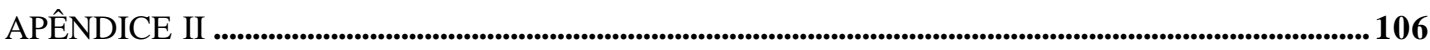




\section{LISTA DE FIGURAS}

FIGURA 2.1 - ESQUEMA DEMONSTRANDO O CORTE ORTOGONAL E O CORTE OBLÍQUO................................ 7

FIGURA 2.2 - ESQUEMA DA OPERAÇÃO DE CORTE ORTOGONAL (SHAW, 1986) ............................................ 9

FIGURA 2.3 - MODELO IDEALIZADO POR PIISPANEN DO PROCESSO DE CORTE............................................ 10

FIGURA 2.4 - ÁREAS DE CONTATO DO CAVACO....................................................................................... 11

FIGURA 2.5 - COMPONENTES DA FORÇA DE USINAGEM NO FRESAMENTO....................................................... 14

FIGURA 2.6 - REGIÕES PRINCIPAIS DE GERAÇÃO DE CALOR. …................................................................. 17

FIGURA 2.7 - DISTRIBUIÇÃO DA TEMPERATURA NA FERRAMENTADE CORTE (MODERN, 1994)................ 17

FIGURA 2.8 - ALGUNS DOS TIPOS DE DESGASTE MAIS COMUNS. ..................................................................... 36

FIGURA 2.9 - DEPRESSÃO E SALIÊNCIA SOBRE A ARESTA DE CORTE DEVIDO A DEFORM AÇÃO PLÁSTICA.

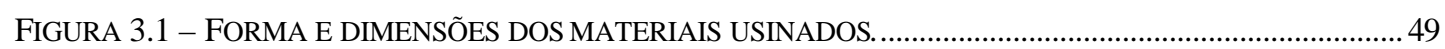

FIGURA 3.2 - MICROESTRUTURA DOS MATERIAIS USINADOS...................................................................... 52

FIGURA 3.3 - ESQUEMA DO INSERTO DE METAL DURO............................................................................... 53

FIGURA 3.4 - CROQUI DA FERRAMENTA DE PCBN. ……….................................................................. 53

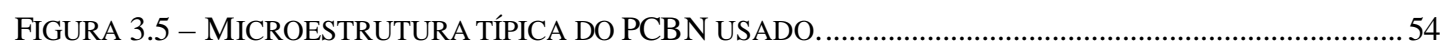

FIGURA 3.6 - BANCO DE ENSAIO UTILIZADO NA EXPERIMENTAÇÃO. ..............................................................5

FIGURA 3.7 - FIXAÇÃO DO SENSOR DE EMISSÃO ACÚSTICA.............................................................................57

FIGURA 3.8 - SISTEMA DE AQUISIÇÃO DO SINAL DE EMISSÃO ACÚSTICA.......................................................58

FIGURA 3.9 - FIXAÇÃO DO BLOCO A SER USINADO NA MESA DO CENTRO DE USINAGEM............................59

FIGURA 3.10 - FIXAÇÃO DA FERRAMENTAPARA MEDIÇÃO DO DESGASTE DE FLANCO...............................60

FIGURA 3.11 - FERRAMENTA FIXADA NO SUPORTE DO MICROSCÓPIO ELETRÔNICO DE VARREDURA.......61

FIGURA 4.1 - RESULTADOS DE EXPERIMENTO DE DESGASTE DE FLANCO E DE RUGOSIDADESUPERFICIAL

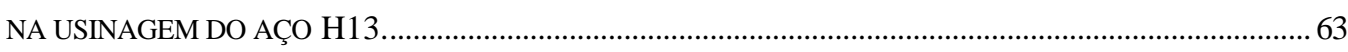

FIGURA 4.2 - RESULTADOS DE EXPERIMENTO DE DESGASTE DE FLANCO E DE RUGOSIDADE SUPERFICIAL

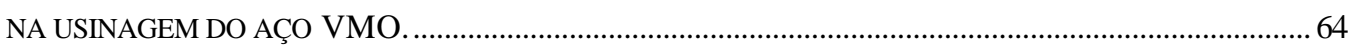

FIGURA 4.3 - RESULTADOS DE EXPERIMENTO DE DESGASTE DE FLANCO E DE RUGOSIDADESUPERFICIAL

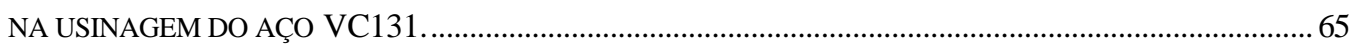

FIGURA 4.4 - GRÁFICOS DE DESGASTE DE FLANCO E DE RUGOSIDADE SUPERFICIAL NA USINAGEM DO

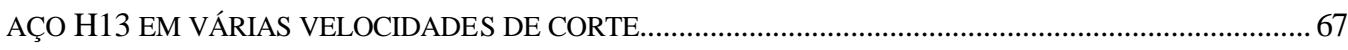

FIGURA 4.5 - GRÁFICOS DE DESGASTE DE FLANCO E DE RUGOSIDADE SUPERFICIAL NA USINAGEM DO AÇO VMO EM VÁRIAS VELOCIDADES DE CORTE.

FIGURA 4.6 - GRÁFICOS DE DESGASTE DE FLANCO E DE RUGOSIDADE SUPERFICIAL NA USINAGEM DO AÇO VC131 EM VÁRIAS VELOCIDADES DE CORTE..

FIGURA 4.7 - DESGASTE E RUGOSIDADE DO AÇO H13 COM FERRAMENTA DE MD COM VARIAÇÃO DA VELOCIDADE DE CORTE E DO AVANÇO.

FIGURA 4.8 - FERRAMENTA DE PCBN DESGASTADA NA USINAGEM DO AÇO H13, COM A VELOCIDADE DE CORTE DE 60 M/MIN. 
FIGURA 4.9 - FERRAMENTA DE MD DESGASTADA NA USINAGEM DO AÇO H13, COM A VELOCIDADE DE CORTE DE 60 M/MIN....... 73

FIGURA 4.10 - FERRAMENTA DE PCBN DESGASTADA QUANDO USINANDO O AÇO VMO, COM A VELOCIDADE DE CORTE DE $60 \mathrm{M} / \mathrm{MIN}$ .74

FIGURA 4.11 - FERRAMENTA DE MD DESGASTADA QUANDO USINANDO O AÇO VMO, COM A VELOCIDADE DE CORTE DE $60 \mathrm{M} / \mathrm{MIN}$. 75

FIGURA 4.12 - FERRAMENTA DE PCBN DESGASTADA QUANDO USINADO O AÇO VC131, COM A VELOCIDADE DE CORTE DE 60 M/MIN 76

FIGURA 4.13 - FERRAMENTA DE MD DESGASTA QUANDO USINANDO O AÇO VC131 COM A VELOCIDADE

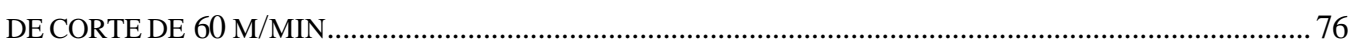

FIGURA 4.14 - FERRAMENTA DE PCBN DESGASTADA QUANDO USINANDO O AÇO H13, COM A VELOCIDADE DE CORTE DE $100 \mathrm{M} / \mathrm{MIN}$ 77

FIGURA 4.15 - FERRAMENTA DE MD DESGASTADA QUANDO USINANDO O AÇO H13, COM A VELOCIDADE DE CORTE DE $100 \mathrm{M} / \mathrm{MIN}$ 78

FIGURA 4.16 - FERRAMENTA DESGASTADA NA USINAGEM DO AÇO H13, COM A VELOCIDADE DE CORTE DE 180 M/MIN 79

FigURA 4.17 - FERRAMENTA DE MD DESGASTADA NA USINAGEM DO AÇO VMO, COM A VELOCIDADE DE CORTE DE $180 \mathrm{M} / \mathrm{MIN}$ 80

FIGURA 4.18 - FERRAMENTA DE MD DESGASTADA QUANDO USINANDO O AÇO VC131, COM A VELOCIDADE DE CORTE DE $180 \mathrm{M} / \mathrm{MIN}$.....

FIGURA 4.19 - FERRAMENTA DE PCBN QUE SOFREU SEVERO LASCAMENTO DEVIDO O USO DE FLUIDO DE CORTE. 81

FIGURA 4.20 -MICROESTRUTURA DEPOIS DE USINADA. 84

FIGURA 4.21 -CRESCIMENTO DA EMISSÃO ACÚSTICA COM O AUMENTO DA VELOCIDADE DE CORTE. .... 86 FIGURA 4.22 - DIFERENTES NÍVEIS DE EMISSÃO ACÚSTICA, PARA CADA MATERIAL DE USINADO, COM FERRAMENTAS DE MD. 88

FIGURA 4.23 - DIFERENTES NÍVEIS DE EMISSÃO ACÚSTICA, PARA CADA MATERIAL USINADO, COM FERRAMENTAS DE PCBN. 89

FIGURA 4.24 - COMPARAÇÃO DE VOLUME DE MATERIAL REMOVIDO PARA AS FERRAMENTAS DE PCBN E MD. 93

FIGURA 4.25 - CUSTO DE USINAGEM PARA CADA MATERIAL USINADO POR FERRAMENTA DE CORTE.....99 


\section{LISTA DE TABELAS}

TABELA 2.1 - AlgunS EXEMPLOS DE MATERIAIS CERÂMICOS (BAUMGARTEN, 1988). 25

TABELA 2.2 - CERÂMICAS USADAS COMO FERRAMENTAS DE CORTE (BAUMGARTEN, 1988).................... 25

TABELA 2.3 - PROPRIEDADES DE ALGUNS MATERIAIS DE FERRAMENTA (ABRÃO, ET AL., 1993)............... 27

TABELA 2.4 - MECANISMOS DE DESGAST E.......................................................................................... 32

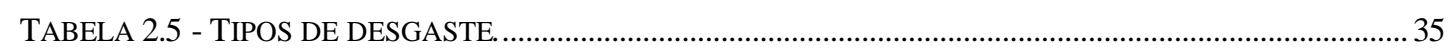

TABELA 3.1 - COMPOSIÇÃO QUÍMICA DOS AÇOS USINADOS.............................................................................. 49

TABELA 3.2 - VALORES DE DUREZA PARA CADA BLOCO DE MATERIAL AO LONGO DA EXPERIMENTAÇÃO. 50

TABELA 3.3 - PARÂMETRO DE CORTE ADOTADOS...................................................................................... 55

TABELA 3.4 - MATRIZ DE EXPERIMENTOS. ............................................................................................................ 56

TABELA 4.1 - VARIAÇÃO DA VOLTAGEM RMS MÉDIA COM O MATERIAL DA FERRAMENTA..................... 90 


\section{LISTA DE ABREVIATURAS E SIGLAS}

AISI - American Iron and Steel Institute

EA - Emissão Acústica

ISO - International Standards Organization

MD - Metal Duro

PCBN -Polycrystalline Cubic Boron Nitride

PCD - Polycrystalline Diamond

RMS - Root Mean Square

SAE - Society American Engineering 


\section{LISTA DE SíMBOLOS}

A - Área da seção transversal de corte $\left[\mathrm{mm}^{2}\right]$

$\mathrm{a}_{\mathrm{p}}$ - Profundidade de usinagem [mm]

$\mathrm{f}$ - Avanço [mm/rot]

K - Constante

$\mathrm{k}_{\mathrm{s}}$ - Pressão específica de corte $\left[\mathrm{N} / \mathrm{mm}^{2}\right]$

$\mathrm{P}_{\mathrm{a}}-$ Força de avanço [N]

$\mathrm{P}_{\mathrm{c}}-$ Força de corte $[\mathrm{N}]$

$\mathrm{P}_{\mathrm{p}}$ - Força de passiva ou profundidade $[\mathrm{N}]$

$\mathrm{P}_{\mathrm{u}}-$ Força de usinagem $[\mathrm{N}]$

$\mathrm{R}_{\mathrm{c}}$ - Recalque do cavaco ou taxa de deformação do cavaco

$\mathrm{t}_{1}$ - Espessura do cavaco não deformado [mm]

$\mathrm{t}_{2}$ - Espessura do cavaco deformado [mm]

$\mathrm{V}_{\mathrm{B}}$ - Desgaste de flanco [mm]

$\mathrm{V}_{\mathrm{c}}$ - Velocidade de corte [ $\left.\mathrm{m} / \mathrm{min}\right]$

$\mathrm{V}_{\mathrm{ca}}$ - Velocidade do cavaco [m/min]

$\gamma$ - Ângulo de saída da ferramenta [graus]

$\phi$ - Ângulo de cisalhamento [graus]

$\chi_{\mathrm{r}}$ - Ângulo de posição [graus]

$\tau_{\mathrm{r}}-$ Tensão de cisalhamento $\left[\mathrm{N} / \mathrm{mm}^{2}\right]$ 


\section{RESUMO}

O fresamento de topo de aços ferramenta, no estado endurecido, pode ser uma alternativa para a fabricação de moldes e matrizes, com alta taxa de remoção. Este trabalho estuda os tipos e mecanismos de desgaste presentes nesta operação de usinagem, bem como o comportamento da emissão acústica. São realizados experimentos com ferramentas de PCBN e Metal Duro usinando os aços H13 (49-51 HRc), VMO (54-57 HRc) e VC131 (57-59 HRc).

$\mathrm{O}$ desgaste das ferramentas de PCBN é significativamente menor que o desgaste das ferramentas de Metal Duro. O tipo de desgaste predominante é o desgaste de flanco, com indícios de desgaste de cratera. É observada uma combinação entre os mecanismos de desgaste abrasivo e adesivo. Não se observa a formação de trincas abaixo da superfície usinada. Verifica-se que a emissão acústica aumenta com a velocidade de corte e mostra-se também dependente do material da peça e da ferramenta.

Palavras Chave: Material endurecido, PCBN, Metal Duro, Fresamento de topo. 


\section{ABSTRACT}

The endmilling operation applied to the machining of hardened tool steels, can be seen as an alternative $\mathbf{b}$ the conventional sequence of operations used in dies and injection moulds. Normally, eletrodischarge machining, which has a low removal rate, is applied for the finishing operation, just before polishing. The present research work study the types and mechanisms of wear that appear in this machining operation, as well as, the behaviour of Acoustic Emission (EA). Experiments are carried out using PCBN and Carbide tools, machining AISI H13 (49-51 HRc), AISI 6F3 (54-57 HRc) e AISI D6 (57-59 HRc).

The wear observed on the PCBN tools was smaller than that on the carbide ones. The type of wear dominating was flank wear, with some presence of crater wear in a few machining conditions. It was also observed a combination between the abrasive and the adhesive mechanisms. It was not noted any cracks on the surface just below the machined surface. The acoustic emission showed to be directly proportional to the cutting speed and also dependent upon the workpiece material and to the tool material.

Key Words: Hardened Material, PCBN, Carbide, Endmilling 


\section{0 - INTRODUÇÃO}

A história do homem tem sido ligada à sua habilidade de modificar o meio ambiente de forma a favorecê-lo. A usinagem é uma forma relativamente recente de transformação dos materiais metálicos em componentes utilizáveis em máquinas e equipamentos. Começou a ser empregada há cerca de 2 séculos (Modern, 1994). A vasta maioria dos produtos metálicos, fabricados pela indústria em geral, requer operações de usinagem em algum estágio de sua produção. Estas variam, desde de operações de desbaste com baixa precisão dimensional, tais como, limpeza de forjados e fundidos, até operações de alta precisão envolvendo tolerâncias dimensionais e geométricas abaixo de $0,001 \mathrm{~mm}$ associadas a baixos valores de rugosidade superficial. Desta forma, a usinagem é indubitavelmente um dos mais importantes processos de fabricação para a indústria metal-mecânica moderna.

As operações de usinagem são diretamente, ou indiretamente, responsáveis pela maior parte da transformação dos materiais de fabricação mecânica em bens acabados (bens de consumo) ou em insumos (bens de produção) para uma grande diversidade de empresas, sendo portanto, de vital importância econômica na geração de lucro para a indústria de transformação.

O processo de usinagem sofreu grande desenvolvimento durante o século XX. Neste mesmo período, por exigência principalmente dos produtos, os materiais de fabricação mecânica também evoluíram, tornando-se cada vez mais difíceis de se usinar. Por outro lado, as indústrias sempre procuram aumentar a produtividade, através de custos e tempos de produção cada vez menores, a fim de que a atividade seja rentável em mercados cada vez mais concorridos. Na realidade de hoje, com a economia globalizada, pode-se dizer que somente haverá mercado para negócios que sejam capazes de reunir tecnologia, por exemplo de usinagem, e eficiência na gerência dos recursos disponíveis. 
A maioria dos materiais de fabricação mecânica usinados está no estado recozido ou normalizado, onde suas propriedades mecânicas facilitam a formação de cavacos. Entretanto, em algumas situações, o componente mecânico deve sofrer tratamento térmico, (têmpera seguida, ou não, de revenimento, cementação, nitretação, etc.), para aumento dos valores de algumas propriedades mecânicas, após o qual deve ser usinado para acabamento. Para esta usinagem final, normalmente opta-se por processos abrasivos (retificação, brunimento, etc.), devido às dificuldades de se usinar por processos convencionais (torneamento, fresamento, etc.) que se utilizam de ferramentas com geometria de ponta definida. Estas dificuldades estão ligadas, principalmente, ao desgaste das ferramentas de corte. Os processos abrasivos, por outro lado, apesar de serem capazes de atingir baixos valores de rugosidade superficial e de tolerâncias dimensionais e geométricas, exigem que se trabalhe com baixas taxas de remoção, caso contrário os danos superficiais e sub-superficiais podem reduzir o tempo de vida do componente solicitado à fadiga. Sendo assim, deve-se procurar processos capazes de usinar o componente no estado endurecido que tenham maior capacidade de remoção, causando o menor dano possível à superfície acabada. $\mathrm{O}$ corte de material endurecido, no entanto, gera altas temperaturas na região de corte, sendo este o principal fator para o aparecimento dos diversos mecanismos e tipos de desgaste nas ferramentas com ponta de geometria definida. Adicionalmente, o material endurecido possui maiores valores de tensões de ruptura ao cisalhamento e tração, dificultando a formação do cavaco e exigindo maiores valores de força de usinagem.

A fabricação de matrizes de forjamento, extrusão e de moldes de injeção de plástico e alumínio é um exemplo prático onde pode-se usinar o material no estado endurecido evitando-se a longa sequiência de fabricação que, geralmente é empregada. Na maioria dos casos, o bloco de material amolecido é fresado (fresamento de topo) no estado recozido até a forma próxima da desejada. Depois o bloco pré-usinado é tratado termicamente (têmpera e revenido) e só então suas formas e dimensões finais são produzidas através da eletroerosão, processo caro e demorado (pela confecção da ferramenta (eletrodo) e tempo de usinagem).

A necessidade de se investigar o fresamento de material endurecido, é a principal motivação para a realização desse trabalho, o que economizaria tempo 
em uma série de sequiências de fabricação envolvendo materiais endurecidos. O maior problema que se espera encontrar é a capacidade das ferramentas de resistir ao desgaste, além da ductilidade devido ao corte ser interrompido. Como a temperatura de corte é também muito elevada, assim como a pressão na aresta de corte, o material da ferramenta é muito exigido, possivelmente apresentando um desgaste elevado.

Devido às severas condições de corte a que está sujeita a ferramenta, seu desgaste, ou quebra, pode ser monitorado através do sinal de Emissão Acústica (EA). Um sensor piezoelétrico colocado próximo à peça poderia captar o "som" do fresamento, fornecendo um sinal para monitoramento do processo. Este monitoramento poderia auxiliar a decisão do momento de troca do inserto, ou em último caso, parar o processo após a quebra ou lascamento da aresta, impedindo que a operação prossiga danificando outras partes ou componentes. Sabe-se que o sinal RMS (Root Mean Square) do sinal é dependente de vários parâmetros de corte, porém seu exato relacionamento em operação de fresamento de topo em materiais endurecidos não é conhecido.

O presente estudo do fresamento de topo em materiais endurecidos pode ajudar a entender como o desgaste ocorre, identificando quais os mecanismos de desgaste dominantes. O conhecimento do comportamento do desgaste da ferramenta ajudará na escolha do material da ferramenta adequado e dos parâmetros de corte que permitam obter um desempenho satisfatório da usinagem. Os dados obtidos com o sinal RMS de EA contribuirão para o estabelecimento de uma estratégia de monitoramento do processo.

\section{1 - Objetivos}

Este trabalho tem por objetivos:

1) Estudar o desgaste das ferramentas e a rugosidade superficial obtida durante o fresamento de materiais endurecidos (empregados em matrizes e moldes) em diversas condições de corte.

2) Estudar os mecanismos e tipos de desgaste ocorridos durante o fresamento dos mesmos aços endurecidos. 
3) Verificar o comportamento do sinal de emissão acústica com a variação das condições de usinagem e com vários materiais usinados.

\section{2 - Estrutura do trabalho}

É montada uma estrutura para os próximos capítulos que será descrita abaixo:

- Capítulo 2 - Revisão bibliográfica: Aborda o processo de usinagem dos metais sob o ponto de vista básico da formação de cavacos, surgimento das forças de corte e a distribuição da temperatura na região de corte; os materiais de ferramenta, destacando-se suas características mecânicas e desgaste (dividido em mecanismos e tipos de desgaste). Trata também da Emissão Acústica (EA) na usinagem dos metais.

- Capítulo 3 - Trabalho Experimental: descreve-se o banco de ensaios utilizado, o arranjo experimental e o procedimento de trabalho de forma detalhada.

- Capítulo 4 - Resultados e Discussão: apresentação dos resultados obtidos na experimentação e a discussão dos mesmos com base na revisão bibliográfica feita no Capítulo 2.

- Capítulo 5 - Conclusões: Com base na experimentação e na teoria são formuladas as conclusões a respeito do trabalho.

- Capítulo 6 - Sugestões para trabalhos futuros: Algumas sugestões são feitas apontando-se pontos do trabalho que merecem uma investigação mais profunda.

- Capítulo 7 - Bibliografia 


\section{0 - REVISÃO BIBLIOGRÁFICA}

Existem vários métodos de mudança de geometria de uma massa de material para produzir uma peça. Basicamente pode-se dizer que essas mudanças podem ser feitas por:

$>$ União de materiais (ex. soldagem);

$>$ Deslocamento de material de uma região para outra (ex. laminação, forjamento e extrusão);

$>$ Remoção de material (ex. torneamento, retificação e eletroerosão).

A transformação por remoção de material é um dos mais importantes processos de fabricação, caracterizado pela geração de cavaco. Pode ser dvidido dentro das seguintes categorias:

> Usinagem convencional;

$>$ Usinagem por processos abrasivos (retificação);

$>$ Usinagem não convencional.

Esta classificação é devido à característica do cavaco formado em cada processo (tamanho do cavaco) (Shaw, 1986).

A ferramenta de corte é um elemento importante, responsável pelo processo de formação e remoção de cavaco. Várias características das ferramentas de corte são de interesse neste trabalho, entre as quais: os materiais empregados, seus mecanismos de desgaste e suas associação com os tipos de desgaste observados após o trabalho. Esses três assuntos são tratados a seguir, através dos vários tópicos analisados. Por último, são abordados alguns tópicos sobre o uso de EA no monitoramento da usinagem e as fontes geradoras do processo de formação de cavacos. 


\section{1 - O processo de corte dos metais - generalidades}

O processo de corte de metais, por usinagem tem sido assunto de estudos científicos desde o começo do século XX. Descrições de modelos teóricos e empíricos têm mostrado um processo no qual é difícil conseguir-se uma visão absoluta. O processo envolve uma combinação de material de ferramenta, material de peça, alta velocidade relativa entre ambos, elevada temperatura e pressão na região de corte (Modern, 1994).

O processo de corte de metais é, basicamente, um processo de formação de cavacos. O processo é direcionado para a remoção de uma porção de material indesejável, em busca de formas e dimensões bem definidas. O cavaco produzido deve ser controlado para garantir um bom desempenho de corte; e para isso tem de ser conduzido para fora da área de corte, devendo transportar consigo a maior parte do calor gerado no processo. Em alguns casos a formação e remoção do cavaco deve ocorrer de forma eficiente para qualquer volume de metal removido, por exemplo, na furação profunda e no torneamento interno, devido ao espaço limitado dentro do furo.

O entendimento do processo de corte de metais está estreitamente relacionado com algumas das propriedades mecânicas dos vários metais usinados e com o respectivo processo de formação de seus cavacos. A forma e propriedades do cavaco variam consideravelmente com o material da peça usinada. Se este é suficientemente tenaz, o processo de formação dos cavacos tem maior semelhança com um fluxo contínuo de elementos do tipo placa sendo cisalhados consecutivamente, o que ocorre, por exemplo com os aços de baixo carbono e com o alumínio. Por outro lado, se o material tem baixa ductilidade, a possibilidade maior é de que o cavaco seja segmentado, exemplo do que ocorre com a usinagem de ferro fundido cinzento. Estas são apenas indicações gerais de formas de cavaco, que podem também variar de acordo com as condições de corte com a geometria da ferramenta e com a operação de usinagem

Outra variável importante no processo de usinagem é a temperatura gerada. As propriedades mecânicas do material da peça têm grande influência na temperatura de corte gerada no processo. A temperatura, se alta o bastante, pode afetar negativamente a ferramenta de corte causando desgaste acelerado. Materiais 
com maiores valores de dureza, tendem a gerar temperaturas mais altas, como é o caso dos aços ferramenta temperados (Modern, 1994). Pelo contrário, materiais de baixa dureza e com maiores valores de condutividade térmica tendem a gerar menores temperaturas, com é o caso das ligas de alumínio.

A força de corte, necessária para a formação do cavaco, afeta significativamente a potência requerida no processo. Durante muito tempo esta era uma limitação para o processo de torneamento. Hoje, isto não se mostra como fator muito importante, uma vez que as máquinas já possuem motores de tamanho menor e com maior potência. Muitas vezes as forças de corte são fator limitante para os componentes usinados, que podem se deformar excessivamente durante a usinagem.

\subsection{1 - Mecanismo de formação de cavacos no corte ortogonal}

O modelo baseado no corte ortogonal, figura 2.1(a), é o mais utilizado para estudos por ser de geometria mais simples do que o corte oblíquo, figura 2.1(b). No primeiro o ângulo de posição é $90^{\circ}$ enquanto que no segundo pode variar deste valor até próximo de $30^{\circ}$. O mecanismo de corte ortogonal, apesar de suas limitações, é referido com frequiência na literatura especializada e a maioria dos estudos teóricos é realizada sobre este modelo.

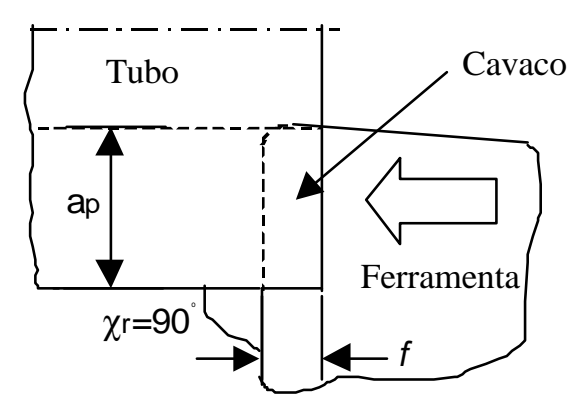

(a) Corte ortogonal

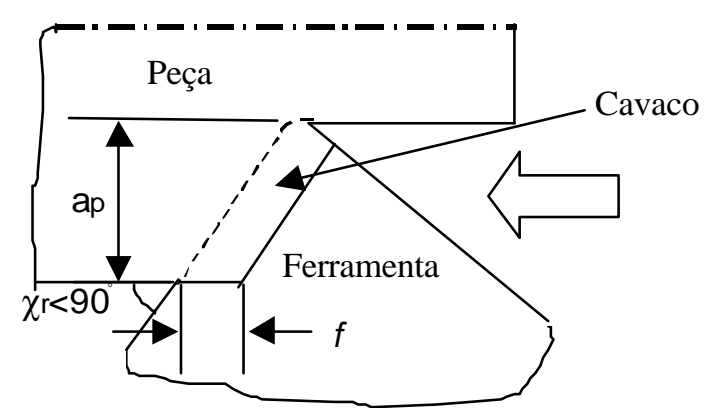

(b) Corte oblíquo

Figura 2.1 - Esquema demonstrando o corte ortogonal e o corte oblíquo. 
O modelo de corte ortogonal "ideal" elimina o conceito de deformação não homogênea do material e assume que este comporta-se de maneira completamente homogênea e isotrópica. As suposições nas quais este modelo bidimensional baseia-se incluem:

1. A ferramenta é perfeitamente afiada e não existe nenhum contato ao longo da face de folga;

2. A superfície onde ocorre o cisalhamento é plana, estendendo para cima da aresta de corte (figura 2.2);

3. A aresta de corte é uma linha reta e gera uma superfície plana quando a peça passa por ela;

4. O cavaco não flui para outros lados (deformação plana), ou seja, para fora do papel (figura 2.2);

5. A profundidade de usinagem é constante;

6. A largura da ferramenta é maior que a da peça;

7. A peça move-se com relação a ferramenta (ou vice-versa) com velocidade uniforme;

8. Um cavaco é contínuo e produzido sem aresta postiça.

9. A tensão de cisalhamento e a tensão normal ao longo do plano de cisalhamento e da ferramenta são uniformes (figura 2.2).

De maneira mais simplificada, a linha de fronteira entre o cavaco e a peça, que separa o metal deformado daquele não deformado, é chamada de plano de cisalhamento, conforme mostrado na figura 2.2. Este forma um ângulo com relação à direção da velocidade de corte, o qual é chamado de ângulo do plano de cisalhamento $(\phi)$. A porção de metal à direita do plano é o cavaco deformado, com espessura (t2), e a porção à esquerda é chamado de cavaco não deformado, cuja espessura é indicado por $\left(t_{1}\right)$. A relação $t_{2} / t_{1}$ é chamada de fator de compressão ou de recalque do cavaco $\left(\boldsymbol{R}_{\boldsymbol{c}}\right)$. O fator de compressão do cavaco está relacionada principalmente com o ângulo de saída da ferramenta $(\gamma)$ e as propriedades mecânicas do material da peça. O ângulo de cisalhamento depende do ângulo de saída da ferramenta $(\gamma)$ e do fator de compressão do cavaco $\left(\boldsymbol{R}_{\boldsymbol{c}}\right)$. Este, por sua vez, depende do material da peça, do material da ferramenta e da refrigeração empregada (Kronenberg, 1966). 


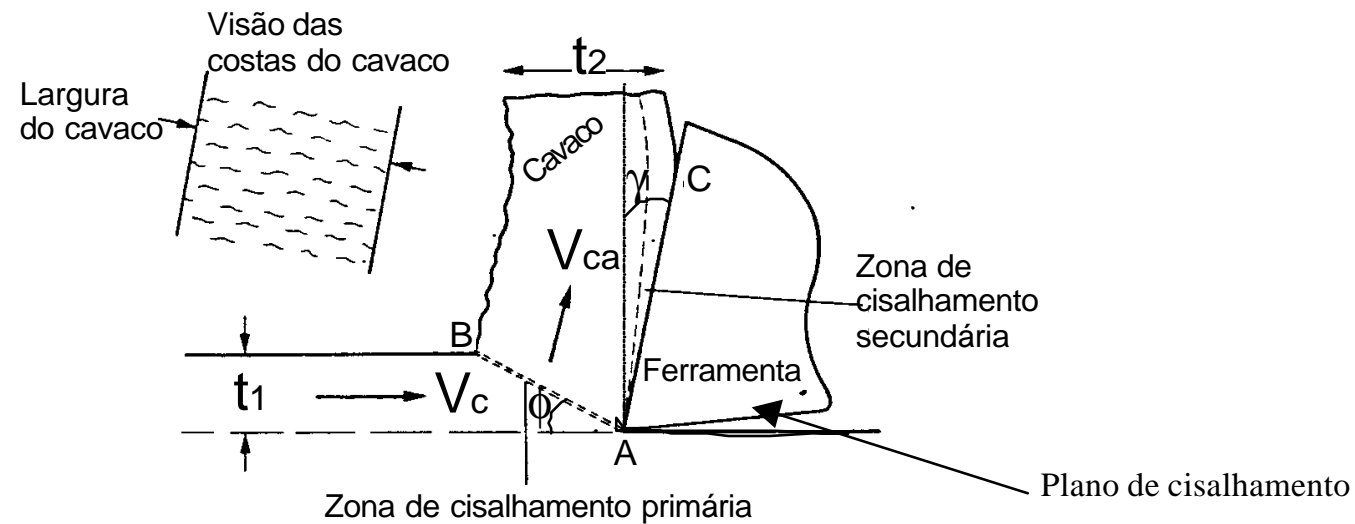

Figura 2.2 - Esquema da operação de corte ortogonal (Shaw, 1986).

Sem dúvida nenhuma, o corte de metais deve envolver o cisalhamento concentrado ao longo de uma zona bastante distinto (figura 2.2). A consideração de uma zona de cisalhamento, ao invés de simplesmente um plano, é necessária, uma vez que se o material passa instantaneamente da condição não deformado para a condição deformado, a transição ocorre em tempo zero, requerendo uma força infinita, ou alternativamente infinita aceleração do material. Já que isto é fisicamente inaceitável, a deformação deve acontecer em uma zona de espessura finita (ASM, 1984).

Nenhum fluxo plástico tem sido relatado, até o presente momento, quando o cavaco prossegue movendo-se sobre a superfície de saída da ferramenta. Há uma pequena quantidade de cisalhamento nesta região, que na maioria dos casos é ignorada em um primeiro tratamento do processo de corte, e o movimento do cavaco ao longo da superfície de saída da ferramenta é simplificadamente considerado como sendo similar a um deslizamento com coeficiente de atrito constante na região de A até $\mathrm{C}$ na figura 2.2.

A superfície posterior do cavaco, oposta àquela em contato com a ferramenta, é rugosa devido à deformação não ser homogênea. Isto é devido à presença de pontos fracos ou de concentração de tensão no metal sendo cortado.

A maneira como o material da peça é removido transformando-se em cavaco foi primeiramente concebido com base num pacote de cartas e é o modelo mais utilizado para explicar o mecanismo de geração do cavaco. Neste modelo o material é dividido em lamelas (cartas), que vão-se cisalhando e deslizando-se à medida que passam pelo plano, ou região, de cisalhamento. Como a ferramenta 
move-se com relação à peça, uma carta é arrancada de cada vez causando, em seguida, o deslizamento da mesma sobre a seguinte. Embora de grandes qualidades didáticas, este modelo apresenta as seguintes limitações (Shaw, 1986):

1. Exagera a não homogeneidade de deformação;

2. Descreve o atrito na face da ferramenta como elástico ao invés de plástico;

3. Assume que o cisalhamento ocorre sobre uma superfície perfeitamente plana;

4. Ignora a aresta postiça que pode estar presente;

5. Envolve um ângulo de cisalhamento assumido arbitrariamente;

6. Não explica o cavaco encaracolado ou prediz o comprimento do contato cavaco-ferramenta.

A despeito de suas limitações, o então chamado "modelo de cartas" do processo de formação de cavacos (figura 2.3) de Piispanen (1937) tem sido muito útil. Contém o conceito principal do processo de formação de cavaco (cisalhamento puro concentrado) e é fácil de ser entendido.

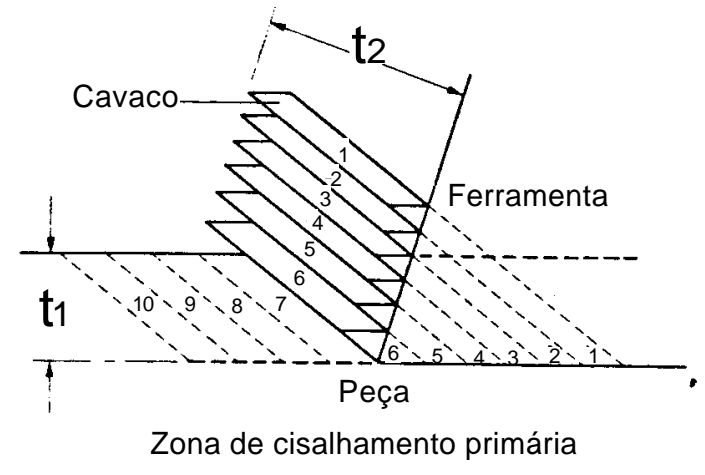

Figura 2.3 - Modelo idealizado por Piispanen do processo de corte.

Outro fator que deve ser considerado no estudo da formação de cavacos é o comportamento plástico do metal no plano de cisalhamento, que tem influência significativa no processo, uma vez que causa o encruamento do cavaco e, em certos casos, da superfície usinada. Isto pode ter como resultado uma mudança da microestrutura da superfície da peça. O encruamento do cavaco aumenta a força de corte e reduz o ângulo de cisalhamento com um cavaco mais espesso fluindo com maior dificuldade sobre a superfície de saída. Portanto, quando o ângulo do plano de cisalhamento é pequeno, a força de corte tende a ser alta, uma vez que o plano de cisalhamento é maior requerendo maior força para atingir a tensão de 
cisalhamento necessária à formação de cavaco. A quantidade de deformação depende consideravelmente, entre outros fatores, do valor do ângulo de saída da ferramenta. Fatores tais como o ângulo de saída e condições de corte também afetam os valores da tensão de cisalhamento.

Materiais com alta resistência mecânica requerem forças de corte maiores que materiais de baixa resistência, causando grande deflexão da peça e da máquina, aumentando o atrito, a geração de calor, requerendo, portanto maior potência de corte.

O contato entre cavaco e ferramenta, ao longo do comprimento de contato (indicado na figura 2.4) pode ser dividido em três regiões onde diferentes reações acontecem no processo: penetração (A), adesão e difusão (B) e abrasão (C) conforme a figura 2.4. Com altas temperaturas a difusão é aumentada (Modern, 1994).
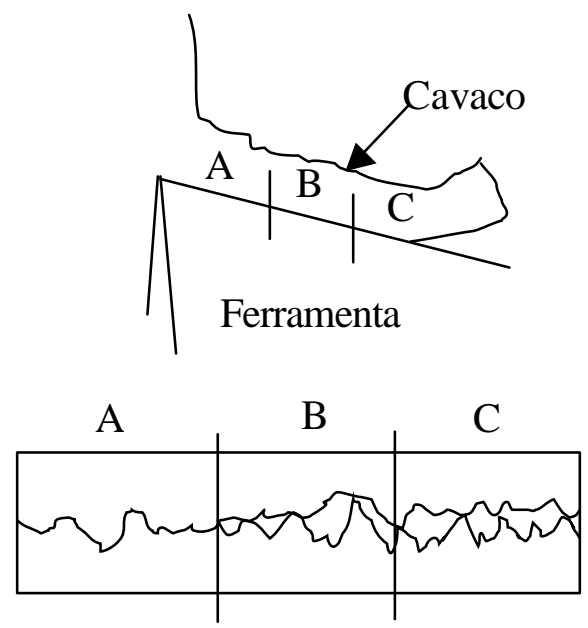

Figura 2.4 - Áreas de contato do cavaco.

Em certas condições de corte e na usinagem de determinados materiais, aparece, na região de adesão, uma camada de material da peça que adere sobre a superfície de saída da ferramenta, devido à uma combinação de baixas temperaturas com altas pressões. Essas camadas se sobrepõem continuamente pressionadas e soldadas tornando-se um material muito duro próximo à aresta de corte, formando a aresta postiça. Esta estrutura altera o ângulo de saída da ferramenta mudando consequentemente o ângulo do plano de cisalhamento e as características do processo de formação de cavacos. A forma da aresta postiça 
afeta especialmente o ângulo de saída e a espessura do cavaco. A formação da aresta postiça aumenta com o maior arredondamento da aresta de corte, mas diminui com o ângulo de saída mais positivo (Modern, 1994). Outro inconveniente é que a aresta postiça de corte é uma estrutura instável, crescendo e se quebrando em períodos de tempo variados. A cada quebra carrega consigo parte do material da ferramenta, levando ao desgaste e diminuição do tempo e vida da ferramenta. O rompimento da aresta postiça também deixa pontos endurecidos na superfície usinada que podem se constituir em pontos de nucleação de trincas durante a solicitação mecânica do componente. Pode ser eliminada pela alteração das condições de corte, principalmente da velocidade.

\subsection{2 - Formação e quebra de cavacos}

Existem sete operações básicas de usinagem com formação de cavaco: aplanainamento, torneamento, fresamento, furação, serramento, brochamento e retificação (usinagem por abrasão) (Degarmo et al., 1997). Em todas elas a forma do cavaco gerado é economicamente importante devido às dificuldades de armazenamento dos mesmos após o corte. Estas formas podem ser classificadas, de maneira geral, em contínuos e segmentados, sendo os últimos mais desejáveis pelas maiores facilidades de manuseio e armazenamento que proporcionam

A maioria dos estudos realizados até o presente tem sido do ponto de vista de corte ortogonal, isto é, uma visão geral simplificada do processo de formação de cavacos. A maior parte das operações de usinagem de metais, no entanto, é oblíqua. Tais mudanças na geometria de corte são consideráveis e a direção fluxo de cavaco é alterada, devido ao ângulo de posição ser diferente de $90^{\circ}$. Também existe mais de uma aresta envolvida, além da variação da velocidade de saída através da largura do cavaco. Ao invés de um cavaco tipo corda de relógio, como aquele obtido em um típica operação de corte ortogonal, pode-se obter várias outras formas de formas de cavaco, por exemplo do tipo vírgula ou helicoidal.

A forma do cavaco inicia-se com uma curvatura inicial e é afetada pela combinação de condições de corte - especialmente o avanço, a profundidade de usinagem, o ângulo de saída, o tipo e o estado do material da peça e também o valor raio de ponta. Quando a curvatura do cavaco torna-se menor para um cavaco 
mais espesso, o comprimento de contato cavaco/ferramenta torna-se mais longo com mais deformação e pressão (Modern, 1994).

A quebra do cavaco, entretanto, não pode ser resolvida apenas selecionando-se várias combinações de parâmetros de corte. Existem outros fatores envolvidos no processo de usinagem os quais podem ser negativamente afetados pelas combinações que consideram somente a quebra do cavaco. As forças de corte, a resistência mecânica da ferramenta, as temperaturas, as vibrações, são exemplos de fatores que se tornam importantes quando a forma do cavaco é variada através das condições de corte.

Cada inserto intercambiável tem um geometria de corte desenvolvida para proporcionar, satisfatoriamente, a formação do cavaco dentro de uma certa faixa de avanços e profundidades de corte, assim como tipos diferentes de material de peça. Um inserto de acabamento trabalha principalmente com raio de ponta, devido aos baixos valores de profundidade de usinagem. Por outro lado, um inseto de desbaste pesado utiliza maior parte da aresta de corte. Alguns insertos são capazes de proporcionar satisfatória formação de cavaco através de uma ampla faixa de valores de avanço e profundidade de usinagem. A adoção de quebracavacos é a forma mais simples para a quebra do cavaco, facilitando o manuseio e armazenamento.

\subsection{3 - Forças de corte}

A tensão aplicada sobre a aresta, através do processo de corte, é principalmente compressiva mas existe também, usualmente, tensão de cisalhamento. A tensão de compressão é maior na ponta da ferramenta reduzindo-se, segundo várias formas (exponencialmente, parabolicamente, etc.), ao longo da superfície de saída. A área de contato entre o cavaco e a superfície de saída da ferramenta está relacionada com as forças de corte e é um importante fator para otimização geométrica do quebra-cavacos. A aplicação de fluido de corte pode também afetar as forças de corte mas este efeito é limitado a baixas velocidade de corte. A força de corte pode ser calculada teoricamente e/ou medida com um dinamômetro. A geometria do processo de formação de cavacos e o atrito no processo faz surgir componentes de força em várias direções. 
Considerando-se o processo de formação de cavacos de um ponto de vista ortogonal, existe um estado de equilíbrio entre as componentes da força de corte no plano de cisalhamento. A força entre a peça e o cavaco, ao longo do plano de cisalhamento, e a força entre a superfície de saída da ferramenta e o cavaco são iguais, de modo que o cavaco formado esteja em equilíbrio.

Em uma visão tridimensional, a força de usinagem $\left(\boldsymbol{P}_{\boldsymbol{u}}\right)$ pode ser dividida em três componentes: força de corte $\left(\boldsymbol{P}_{\boldsymbol{c}}\right)$, força de avanço $\left(\boldsymbol{P}_{\boldsymbol{a}}\right)$ e força passiva $\left(\boldsymbol{P}_{\boldsymbol{p}}\right)$ ou de profundidade, (Ferraresi, 1977), conforme a figura 2.5.

A força de corte $\boldsymbol{P}_{\boldsymbol{c}}$ ) pode ser expressa pelo produto da área da seção transversal de corte $(\boldsymbol{A})$ pela pressão específica de corte $(\boldsymbol{k s})$.

Segundo Ferraresi, 1977 a pressão específica de corte depende de vários fatores; os principais são discutidos abaixo:

Material da peça $-\boldsymbol{k}_{\boldsymbol{s}}$ aumenta com a resistência mecânica do material. Existe uma relação aproximada entre a tensão de cisalhamento $\left(\tau_{r}\right)$ na ruptura do material, a taxa de deformação $\left(\boldsymbol{R}_{\boldsymbol{c}}\right)$ e a pressão específica de corte $\left(\boldsymbol{k}_{\boldsymbol{s}}\right)$ que mostra esta dependência $-\boldsymbol{k}_{\boldsymbol{s}} \cong \boldsymbol{k} . \tau_{\boldsymbol{r}} \boldsymbol{R}_{\boldsymbol{c}}$ - onde $\boldsymbol{k}$ é uma constante. No entanto o aumento de $\boldsymbol{k}_{\boldsymbol{s}}$ não é diretamente proporcional ao aumento de $\tau_{\boldsymbol{r}}$. Com o aumento da resistência mecânica do material, plasticidade do material diminui e o valor de $\boldsymbol{R}_{\boldsymbol{c}}$ torna-se menor.

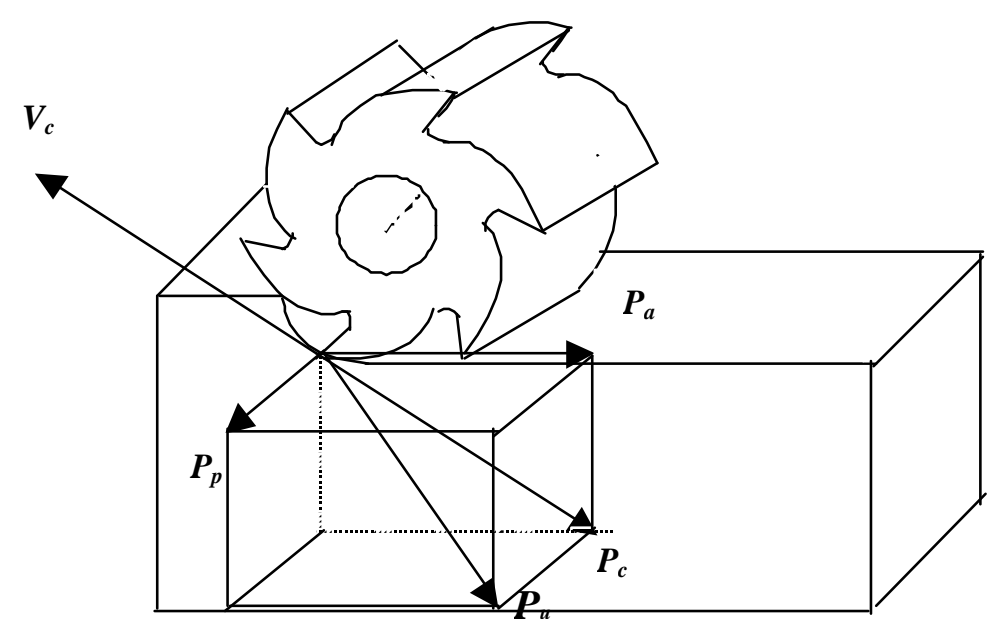

Figura 2.5 - Componentes da força de usinagem no fresamento.

Seção de corte (produto da profundidade de usinagem pelo avanço) - A pressão específica de corte diminui com o aumento da área da seção de corte, 
principalmente devido ao aumento do avanço. $\mathrm{O}$ aumento do avanço diminui a taxa de deformação $\left(\boldsymbol{R}_{\boldsymbol{c}}\right)$, o que diminui $\boldsymbol{k}_{\boldsymbol{s}}$.

Ângulo de saída da ferramenta - Quanto maior o valor do ângulo de saída $(\gamma)$, menor o valor de $\boldsymbol{k}_{\boldsymbol{s}}$; pois a taxa de deformação $\left(\boldsymbol{R}_{\boldsymbol{c}}\right)$ varia com o ângulo $\gamma$.

Velocidade de corte - Na faixa de velocidade de trabalho de vários metais, a pressão específica de corte diminui com a velocidade de corte. Atribui-se como razão, a diminuição da taxa de deformação e da dureza do material do cavaco com o aumento da temperatura.

A força de avanço $\left(\boldsymbol{P}_{\boldsymbol{a}}\right)$ não influi praticamente sobre a potência de usinagem e a força passiva $\left(\boldsymbol{P}_{\boldsymbol{p}}\right)$ não toma parte ativa na determinação da potência da máquina operatriz. Mesmo assim estas forças são de grande importância no projeto e na estabilidade dinâmica da máquina operatriz.

$\mathrm{O}$ relacionamento entre as componentes da força de usinagem varia consideravelmente com o tipo de operação de usinagem. A força de corte $\left(\boldsymbol{P}_{\boldsymbol{c}}\right)$ freqüientemente é dominante nas operações de fresamento e torneamento, especialmente para cálculo da potência requerida. A força passiva $\left(\boldsymbol{P}_{\boldsymbol{a}}\right)$ é de particular interesse na operação de torneamento interno e as forças de avanço $\left(\boldsymbol{P}_{\boldsymbol{a}}\right)$ e de passiva $\left(\boldsymbol{P}_{\boldsymbol{p}}\right)$ na furação. Um aumento na velocidade de corte tem influência favorável sobre a força de usinagem $\left(\boldsymbol{P}_{\boldsymbol{u}}\right)$.

\subsection{4 - Calor no corte de metais}

Toda a energia disponível na aresta de corte durante o processo de corte é convertida em calor, a maioria em calor devido ao atrito ou calor gerado pela destruição das ligações entre os grãos no plano de cisalhamento (Kronenberg, 1966). O calor produzido no corte dos metais depende principalmente da velocidade e da força de corte. $\mathrm{O}$ avanço, no entanto, representa um papel mais moderado com relação à geração de calor. Já o calor dissipado depende do aumento de temperatura do cavaco, da massa do cavaco e do calor específico do material da peça e da ferramenta.

Dados práticos demostram claramente que a maioria do calor dissipado é através do cavaco em movimento. No entanto, não se deve concluir que a temperatura do cavaco é maior que a temperatura da ferramenta. Este 
relacionamento é na maioria dos casos inverso, a temperatura do cavaco é menor que a temperatura da ferramenta, em determinados pontos. Isto pode ser explicado pelo fato de que o cavaco está continuamente em movimento mudando seu ponto de contato com a ferramenta, enquanto que esta permanece sendo atritada sempre nos mesmos pontos. O ponto com temperatura mais alta, na superfície de saída da ferramenta, é ligeiramente afastado da aresta de corte, aproximadamente onde o cavaco deixa de ter contato com a ferramenta (Modern, 1994). A formação do desgaste de cratera, na maioria dos casos, inicia-se neste ponto. Temperaturas excessivas têm sido apontadas como a primeira causa para baixos tempos de vida de ferramenta e limitação da velocidade de corte.

A força de corte $\boldsymbol{P}_{\boldsymbol{c}}$ ) (figura 2.5) agindo durante uma operação com um determinado valor de velocidade de corte representa uma certa quantidade de energia sendo empregada para a remoção de material. Esta é consumida, principalmente, na deformação e cisalhamento da peça, gerando o cavaco. Adicionalmente, alguma energia é usada para arrastar o cavaco sobre a face de saída e contra o quebra-cavacos. Considerável calor é gerado principalmente em três áreas: na zona de cisalhamento, na superfície de saída e na superfície de folga da aresta de corte, conforme mostrado na figura 2.6. A maioria do calor surge na zona de cisalhamento (Modern, 1994). Um pequeno ângulo de cisalhamento, o qual pode ser o resultado de um ângulo de saída menor, pode fazer com que o fluxo de calor seja maior para a peça.

A figura 2.7 mostra o resultado de um estudo sobre temperatura em insertos de torneamento. Pode-se observar as isotermas mostrando os valores de temperatura típicos no interior do inserto e na superfície de saída. Neste caso um aço ligado foi usinado com um inserto de metal duro em alta velocidade de corte. 


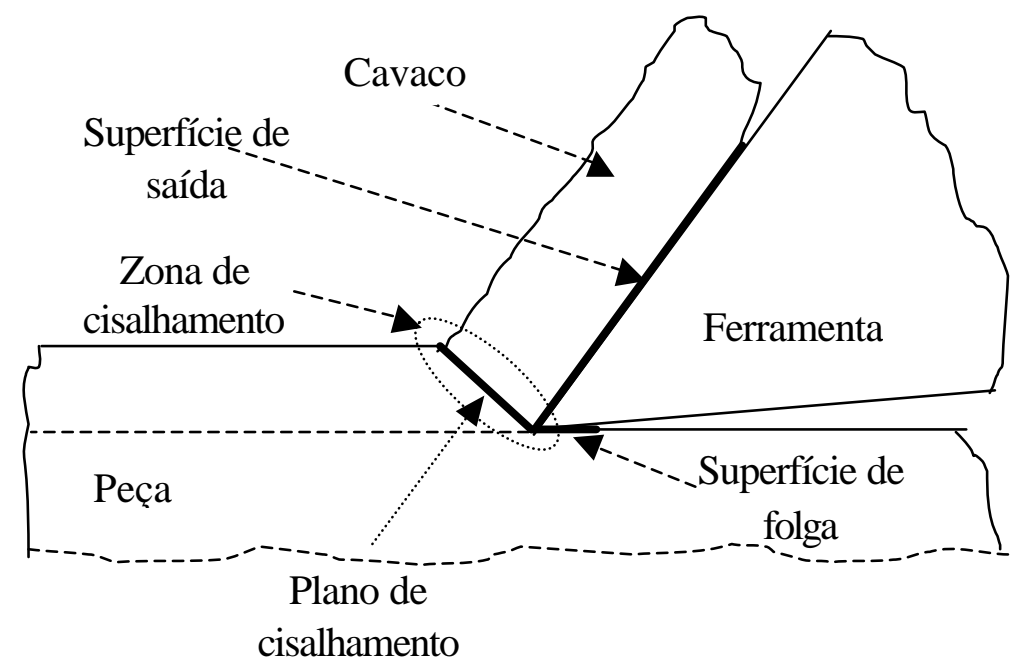

Figura 2.6 - Regiões principais de geração de calor.
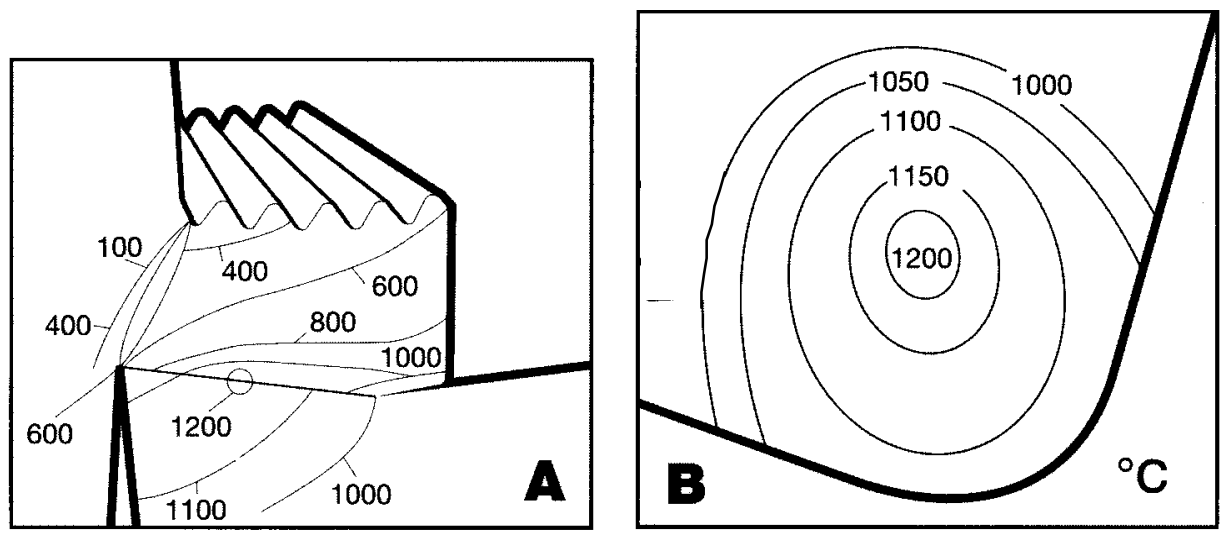

Figura 2.7 - Distribuição da temperatura na ferramenta de corte (Modern, 1994).

De acordo com figura 2.7 pode-se observar que em determinados pontos a temperatura atinge $1200^{\circ} \mathrm{C}$, valor que pode comprometer as propriedades mecânicas da maioria dos materiais comuns de ferramenta. $\mathrm{O}$ desenvolvimento de materiais de ferramenta, no entanto, tem evoluído para classes e composições capazes de suportar os efeitos das altas temperaturas minimizando o problema. $\mathrm{O}$ metal duro pode usinar em torno de duas vezes a temperatura do aço rápido graças à propriedade de maior dureza a quente, materiais com a cerâmica e o PCBN suportam temperaturas ainda mais elevadas.

Menores velocidades de corte, por outro lado, podem não aliviar os efeitos da temperatura gerada durante a formação de cavacos, uma vez que a quantidade 
de calor que flui para a peça é maior. Desta forma a peça tende a sair da máquina com maior temperatura, dificultando a inspeção dimensional. Em altas velocidades de corte o cavaco recebe mais energia que a ferramenta e a peça (Modern, 1994). O calor no cavaco somente afetará a ferramenta de corte ao longo do comprimento de contato existente entre os dois. Este fato é benéfico para a ferramenta por que limita a uma pequena região os efeitos indesejáveis da alta temperatura (difusão química, amolecimento do material da ferramenta e etc.).

\section{2 - Materiais de ferramenta}

O desenvolvimento das ferramentas de corte no último século se deve em grande parte à introdução de novos materiais, tanto para ferramentas quanto para peças, assim como a novas tecnologias empregadas para fabricação e transformação dos mesmos. Existe um amplo espectro de materiais de ferramenta, os quais possuem diversas propriedades, porém as três mais importantes são: estabilidade química e física a altas temperaturas, resistência ao desgaste abrasivo, e resistência a fratura frágil (Shaw, 1986). Contudo nos materiais de ferramenta conhecidos, até o presente, não se observou essas três propriedades reunidas num mesmo material (Shaw, 1986).

Os principais materiais empregados em ferramentas de corte, em ordem cronológica do aparecimento desde o início do século, foram: o aço carbono, o aço rápido, o metal duro (ou carbeto), o cermet, a cerâmica, o PCBN (Polycrystalline Cubic Boron Nitride) e o PCD (Polycrystalline Diamond). Os dois últimos apareceram praticamente juntos por volta de 1975 (Machado, 1988).

\subsection{1 - Aço Carbono}

Na primeira parte do século passado o aço carbono e os aços de baixa e média liga eram os únicos materiais de ferramentas disponíveis. Antes de 1870 todas as ferramentas empregadas em torneamento eram forjadas (o material era aquecido em forjas a carvão e martelado até a forma desejada) a partir de aço carbono, de composição aproximada de $1 \%$ de carbono, $0,2 \%$ de manganês e o restante de ferro. Este aço podia ser usado para a usinagem de aço em baixas 
velocidades de corte (aproximadamente 4,8 $\mathrm{m} / \mathrm{min}$ ). Este material também requer um resfriamento rápido em água para endurecer, o que freqüentemente resulta em trincas causadas pelo resfriamento (Shaw, 1986).

Em 1870 Robert Mushet introduziu um aço na Inglaterra tendo a composição aproximada de: $2 \%$ de carbono, $1,6 \%$ de manganês, 5,5\% de tungstênio, e 0,4\% de cromo. Este material era endurecido ao ar e capaz de manter sua dureza em temperaturas mais altas, possibilitando o emprego de maiores velocidades de corte, em torno de 7,8 m/min. Foram feitas modificações na composição deste aço (principalmente a substituição do manganês por cromo) e foi usado como ferramenta de tornear até o começo do século XX (Shaw, 1986).

A maior deficiência destes aços era a perda de dureza quando submetidos a temperaturas superiores à de revenimento (de $300^{\circ}$ a $\left.600^{\circ} \mathrm{C}\right)$, levando a aresta de corte a um desempenho insatisfatório.

\subsection{2 - Aço Rápido}

F. W. Taylor e M. White (1901) produziram ferramentas que proporcionaram uma maior estabilidade das propriedades mecânicas em temperaturas mais altas, o que permitiu velocidades de corte em torno de 19,2 $\mathrm{m} / \mathrm{min}$ e, em consequiência desta melhora de desempenho, este material ficou conhecido como aço rápido.

Ao contrário da crença comum este não foi o desenvolvimento de um novo aço, mas um novo tratamento térmico para materiais já existente. Taylor e White descobriram que se a ferramenta fosse aquecida rapidamente até uma temperatura próxima ao ponto de fusão, e em seguida resfriado rapidamente, teriam um aço com a dureza a quente melhorada. A composição do aço usado por Taylor e White em 1901 foi aproximadamente 1,9\% de carbono, 0,3\% de manganês, 8\% de tungstênio e 3,8\% de cromo. Diferia do aço original de Mushet principalmente na quantidade de tungstênio e a substituição de manganês por cromo. Em um curto espaço de tempo (1900 à 1910) a velocidade de corte aumentou de 7,8 m/min para mais de $31,2 \mathrm{~m} / \mathrm{min}$.

È bem conhecido que a dureza, a resistência ao desgaste, a capacidade de corte, alta resistência ao amolecimento devido ao calor e a tenacidade do aço 
rápido dependem da composição química, tamanho e distribuição dos carbetos no aço. O carbono e os elementos de ligas (cromo, vanádio, molibdênio, tungstênio) são balanceados para proporcionar as características citadas acima Bayer et al., 1989).

Durante os anos de 1970 o aço rápido sofreu dois significativos desenvolvimentos: o primeiro envolveu o domínio da sinterização do aço rápido. O segundo consistiu em um refinamento mais eficiente dos pós. Isto resultou em partículas individuais tendo muitas pontas afiadas ao invés de superfícies arredondadas produzidas no triturador de bolas. A vantagem é que menos pressão é requerida para a prensagem. Contudo, a principal vantagem da metalurgia do pó para o aço rápido é o desenvolvimento do inserto de aço rápido para uso em porta ferramenta de metal duro. Também foi possível produzir ferramentas complexas como machos, fresas caracol, fresas de topo, etc. com a metalurgia do pó. Outra técnica utilizada na fabricação de ferramentas é a fundição de precisão do aço rápido.

A American Iron and Steel Institute (AISI) introduziu símbolos para as duas principais classes de aço rápido: o símbolo $\mathrm{T}$ designando o aço rápido a base de tungstênio e o símbolo $\mathrm{M}$ para aço rápido a base de molibdênio.

No decorrer do desenvolvimento do aço rápido apareceram as ferramentas revestidas com camadas de nitreto de titânio (TiN), carbeto de titânio (TiC), nitreto de háfnio $(\mathrm{HfN})$ e alumina $\left(\mathrm{Al}_{2} \mathrm{O}_{3}\right)$ pelo processo de deposição física por vapor (PVD - Physical Vapour Deposition) (Bayer et al., 1989).

\subsection{3 - Metal Duro}

O metal duro representou um grande salto de desempenho, permitindo velocidades de corte superiores àquelas conseguidas com o aço rápido e consequentemente uma produtividade mais alta. As primeiras ferramentas de metal duro bem sucedidas foram trazidas para os Estados Unidos da Alemanha em 1938. Essas ferramentas consistiam de partículas de carbeto de tungstênio bem finas, sinterizadas junto com o ligante cobalto.

Gradualmente durante a década de 1930, ferramentas de metal duro de maior resistência ao choque foram produzidas, mas estas foram usadas 
principalmente para tornear ferro fundido e metais não ferrosos devido à grande tendência de formação de cratera na superfície de saída quando usinando aço. Ao redor de 1938 foi descoberto que a tendência à formação de cratera quando usinando aço poderia ser reduzida pela adição de carbeto de titânio (TiC) e carbeto de tântalo (TaC). Durante a Segunda Guerra Mundial o uso de ferramentas de carbeto expandiu-se rapidamente, embora alguns países sofreram com a escassez de cobalto, devido aos bloqueios de guerra. No início, o inseto de carbeto era soldado sobre uma haste de aço, ou sobre a fresa, formando a ferramenta. $\mathrm{Na}$ década de 50, no entanto, o metal duro aparece já na forma de insertos indexáveis, os quais eram fixados mecanicamente em porta-ferramentas. $\mathrm{O}$ desenvolvimento de insertos de metal duro teve significativa contribuição, não somente em relação à evolução da geometria da aresta de corte, incluindo o quebra cavaco, mas também no desenvolvimento e diversificação de materiais para ferramentas.

A International Standards Organization (ISO) criou uma classificação para o metal duro - Uma classe destinada principalmente à usinagem de ferro fundido cinzento, metais não ferrosos e metais abrasivos como fibra de vidro e grafite que produzem cavacos curtos (ISO tipo K) e outra para a usinagem de metais ferrosos que produzem cavaco longo (ISO tipo $\mathrm{P}$ ). A classe $\mathrm{K}$ consiste de cristais de carbeto de tungstênio (WC) com normalmente 3 a $12 \%$ de cobalto como ligante enquanto a classe $\mathrm{P}$ o ligante também é o cobalto e tem parte WC substituído por $\mathrm{TiC}, \mathrm{TaC}$ ou carbeto de nióbio $(\mathrm{NbC})$, todos com diferentes graus de perda de resistência mecânica, resistência ao desgaste abrasivo, ao impacto, e a corrosão (oxidação). Além dessas duas classes existem uma terceira a $\mathrm{M}$ que é uma categoria intermediária para ferro fundido dúctil e aços duros.

O metal duro é fabricado por um processo de metalurgia do pó consistindo em uma sequiência de passos que devem ser cuidadosamente controlados para a obtenção de um produto final com as propriedades, microestrutura e desempenho desejado. O desempenho das ferramentas de metal duro é fortemente dependente da composição e da microestrutura, e suas propriedades dependem não somente do tipo e quantidade de carbeto mas também do tamanho de grão do carbeto e da quantidade de metal ligante. Outro fato importante é que a ductilidade do metal duro é baixa na temperatura ambiente, existindo um pequena diferença entre sua 
resistência ao escoamento e a resistência à ruptura. Em altas temperaturas entretanto, a ductilidade aumenta (Santhanam et al., 1989).

O mais importante desenvolvimento em ferramentas da década de 1960 foi a introdução do metal duro recoberto, em torno de 1969. O esforço inicial nesta direção envolveu as classes de metal duro para a usinagem de aço que foram produzidas com uma fina camada de TiC. A espessura da cobertura do TiC foi ao redor de 0,005 $\mathrm{mm}$. Tais coberturas reduzem a tendência de formação de cratera na ferramenta de metal duro quando usinando aço doce e assim possibilitar a usinagem de aços de baixa liga com avanços e velocidades de corte mais altas. A cobertura dos insertos de metal duro pode ser realizada com uma camada simples (ex. TiC), dupla (ex. TiC- $\mathrm{Al}_{2} \mathrm{O}_{3}$ ) ou tripla (ex. TiC-Ti(C,N)). A espessura do revestimento depende da operação que se pretende realizar (ex. torneamento, fresamento, etc.), pois tem influência na vida e no desgaste da ferramenta (Sasaki et al., 1982). Os primeiros recobrimentos (TiC) foram realizados pelo processo CVD (Chemical Vapor Deposition). No começo da década de 80 foi introduzido o processo de recobrimento PVD (Physical Vapor Deposition) e os recobrimentos eram feitos com TiN (Takatsu, 1990).

Os principais fatores que influenciam no corte com metal duro recoberto são os tipos de cobertura, a espessura da camada de recobrimento, o método de recobrimento e o substrato. As características de desgaste dependem do tipo de cobertura. De um modo geral a resistência ao desgaste térmico obedece à seguinte classificação alumina $\left(\mathrm{Al}_{2} \mathrm{O}_{3}\right)>$ nitreto de titânio $(\mathrm{TiN})>$ carbonitreto de titânio $(\mathrm{TiCN})>$ carbeto de titânio $(\mathrm{TiC})$, porém no desgaste abrasivo esta ordem se inverte (Takatsu, 1990).

\subsection{4 - Cermet}

O Cermet é um material intermediário entre o metal duro e a cerâmica. Surgiu na metade da década de 50, mas só foi amplamente usado da década de 80 (Takatsu, 1990). É constituído, essencialmente, de um componente cerâmico com um outro metálico. O componente cerâmico do cermet proporciona alta dureza a quente e resistência a oxidação, enquanto o componente metálico acentua a resistência ao choque térmico e a ductilidade (Gruss, 1989). As cerâmicas mais 
comuns são o TiC e o TiN tendo o níquel (Ni) (um metal) como elemento de liga. Tem sua maior aplicação em superacabamento de aços, com altas velocidades de corte e baixos avanços, embora também possa ser usado nas operações de desbaste. Possui alta dureza a elevadas temperaturas e grande estabilidade química, com pouca tendência à difusão.

As classes de cermet mais recentes junto com projetos inovadores de insertos têm expandido grandemente o campo de aplicação destas ferramentas de corte. De uma modo geral o cermet possui algumas vantagens em relação aos outros materiais de ferramentas dentro de condições de corte mais suaves; algumas vantagens são: superior resistência ao desgaste abrasivo e de adesão e possibilidade de trabalho em altas velocidades de corte (McGraw et al., 1997).

Cermet à base de TiC, em comparação com o metal duro à base de WC, permite velocidades de corte mais altas devido ao TiC ser termicamente mais estável que o WC. Outras comparações adicionais podem ser feitas entre o cermet e o metal duro:

- A dureza do cermet $\mathrm{Ti}(\mathrm{CN})$ é comparável à do metal duro.

- A resistência mecânica do metal duro é de 15 a $25 \%$ maior que a resistência do cermet $\mathrm{Ti}(\mathrm{CN})$. Como resultado a taxa de avanço e a profundidade de usinagem para o cermet tem que ser selecionada mais preventivamente especialmente na operação de desbaste.

- A variação de tenacidade do cermet $\mathrm{Ti}(\mathrm{CN})$ é menor que o metal duro, limitando o uso deste cermet em operações de desbaste pesado. Entretanto, a resistência a fratura do cermet a base de TiC pode ser a mesma do carbeto de tungstênio - cobalto (WC-Co), quando forem equivalentes o volume de ligante e o tamanho de grão do carbeto.

- A resistência ao choque térmico do cermet Ti(CN) é menor que a do metal duro e restringe o uso de refrigerante em aplicações de desbaste.

\subsection{5 - Cerâmica}

Ferramentas de corte de cerâmica foram colocadas em uso nos Estados Unidos em meados da década de 1950 (Machado, 1988) (Shaw, 1986), depois de terem sido usadas na Russia, Inglaterra e Alemanha. A maioria destas ferramentas 
é feita de $\alpha-\mathrm{Al}_{2} \mathrm{O}_{3}$ fina sinterizada, sem ligante ou outro aditivo. As ferramentas cerâmicas são mais refratárias e mais duras que as ferramentas de metal duro, mas também são mais frágeis. Para produzir uma tenacidade razoável é importante que a ferramenta de $\mathrm{Al}_{2} \mathrm{O}_{3}$ tenha um tamanho de grão muito pequeno e seja sinterizada essencialmente até a máxima densidade.

As cerâmicas proporcionam características desejáveis para materiais de ferramenta, uma vez que apresentam boa dureza a quente e resistência ao desgaste químico, abrindo a possibilidade de redução de desgaste da ferramenta em altas temperaturas. Essas propriedades permitem às ferramentas cerâmicas serem usadas com sucesso em usinagem de alta velocidade (acima de $300 \mathrm{~m} / \mathrm{min}$ ) (ElBestawi et al., 1993) (Narutaki et al., 1993). A primeira dificuldade, entretanto, é que a cerâmica tem baixas tenacidade à fratura e resistência à ruptura transversal, em relação ao metal duro. A cerâmica também tem baixa resistência ao choque térmico, o qual depende da tenacidade a fratura, do módulo de Young, do coeficiente de expansão térmico e da condutividade térmica (Komanduri et al., 1989).

A influência das propriedades das cerâmicas sobre as condições de usinagem são de elevada importância. A resistência mecânica e a tenacidade são importantes durante o corte interrompido, nos altos valores de avanço e alta profundidade de usinagem, enquanto a dureza a quente e a resistência a abrasão são mais importantes com o aumento da velocidade de corte. A resistência ao choque térmico é desejada quando altas tensões mecânicas, alta velocidade de corte, ou uso de fluido de corte estão envolvidos.

Ser quimicamente inerte é também uma propriedade importante a altas temperaturas de corte. $\mathrm{A}_{\mathrm{Al}_{2} \mathrm{O}_{3}}$ é a cerâmica mais quimicamente inerte, enquanto o nitreto de silício $\left(\mathrm{Si}_{3} \mathrm{~N}_{2}\right)$ e o carbeto de silício $(\mathrm{SiC})$ são mais reativos que o cobalto e o ferro. A reatividade do $\mathrm{SiC}$ com materiais ferrosos parece ser a razão porque a $\mathrm{Al}_{2} \mathrm{O}_{3}$ reforçada com bastonetes, "whisker", de $\mathrm{SiC}$ é limitada para aplicações com peças de super ligas à base de níquel (Komanduri, et al., 1989).

A primeira cerâmica sinterizada, $\mathrm{Al}_{2} \mathrm{O}_{3}$, tinha a mais alta estabilidade química entre os materiais conhecidos até então, mostrando-se o melhor material de ferramenta para resistir ao desgaste a altas velocidades de corte. Por outro lado sua atuação era limitada pela sua fragilidade, fato este contornado com a 
introdução das cerâmicas mistas, reforçadas com TiC, TiN, SiC (na forma de "whiskers"). Com tais cerâmicas conseguiu-se usinar materiais endurecidos com altas velocidades de corte obtendo-se bons resultados (El-Bestawi et al., 1993), (Narutaki et al., 1993). Atualmente a cerâmica tem um lugar de destaque, pois tem inúmeras aplicações em diversas operações de usinagem; isso justifica o fato de países como o Japão e Estados Unidos investirem em pesquisa e desenvolvimento (Baumgarten, 1988) destes materiais. São feitas a partir de óxidos, nitretos , carbonetos e boretos; a tabela 2.1 mostra alguns exemplos. A porcentagem adequada dessas substâncias na composição da cerâmica confere propriedades desejadas, como por exemplo a adição de pequenos percentuais de óxido de zircônio $\left(\mathrm{ZrO}_{2}\right)$ à $\mathrm{Al}_{2} \mathrm{O}_{3}$ objetivando a melhoria da tenacidade (Baumgarten, 1988).

Tabela 2.1 - Alguns exemplos de materiais cerâmicos (Baumgarten, 1988).

\begin{tabular}{|c|c|c|c|}
\hline Óxidos & Nitretos & Carbonetos & Boretos \\
\hline $\mathrm{Al}_{2} \mathrm{O}_{3}$ & $\mathrm{Si}_{3} \mathrm{~N}_{4}$ & $\mathrm{WC}$ & $\mathrm{TiB}_{2}$ \\
$\mathrm{Al}_{2} \mathrm{O}_{3}+\mathrm{ZrO}_{2}$ & $\mathrm{AIN}$ & $\mathrm{SiC}$ & $\mathrm{ZrB}_{2}$ \\
$\mathrm{ZrO}_{2}$ & $\mathrm{HfN}$ & $\mathrm{TiC}$ & $\mathrm{TaB}_{2}$ \\
$\mathrm{TiO}_{2}$ & $\mathrm{TiN}$ & $\mathrm{HfC}$ & $\mathrm{NbB}_{2}$ \\
\hline
\end{tabular}

Na tabela 2.2 estão algumas cerâmicas que são usadas como ferramenta de corte.

Tabela 2.2 - Cerâmicas usadas como ferramentas de corte (Baumgarten, 1988).

\begin{tabular}{|c|c|}
\hline Matriz & Aditivos \\
\hline $\mathrm{Al}_{2} \mathrm{O}_{3}$ & $\mathrm{ZrO}_{2}$ \\
$\mathrm{Al}_{2} \mathrm{O}_{3}$ & $\mathrm{TiC}$ \\
$\mathrm{Si}_{3} \mathrm{~N}_{4}$ & \\
$\mathrm{TiN}$ & \\
\hline
\end{tabular}

Devido às cerâmicas serem relativamente frágeis, uma preparação especial da aresta de corte é necessária para prevenir lascamento ou quebra da aresta 
(Komanduri et al., 1989). Duas operações podem ser realizadas: uma consiste em um microscópico arredondamento da aresta de corte (ou "honing", como é conhecido) outra em chanfrar com 0,05 a 0,15 mm de uma largura com ângulo em torno de $20^{\circ}$ a $45^{\circ} \mathrm{em}$ relação à superfície de saída. Em certos caso as duas operações podem ser aplicadas simultaneamente. As cerâmicas foram usadas inicialmente com ângulo de saída negativo e aresta chanfrada, embora melhoramentos nas técnicas de fabricação, propriedades mecânicas, e máquinas ferramentas mais rígidas permitam um ângulo de saída positivo (Komanduri et al., 1989).

\subsection{6 - Materiais ultraduros}

O PCD (Polycrystalline Diamond) e o PCBN (Polycrystalline Cubic Boron Nitride) apareceram durante a década de 70 , sendo sua principal aplicação a usinagem de materiais difíceis, pelo fato de possuírem dureza superior aos demais empregados em ferramentas de corte, conforme tabela 2.3. O PCD normalmente é usado na usinagem de materiais não-metálicos muito abrasivos (ex. grafite, plásticos, e plásticos reforçados com fibra de vidro) e não-ferrosos (ex. alumínio, cobre e suas ligas e Metal Matrix Composite (MMC)) (Kalish, 1983). A principal aplicação do PCBN reflete sua habilidade de manter a dureza em alta temperatura e sua relativa baixa solubilidade em ferro, de tal modo que ele é a ferramenta mais adequada para corte de ligas de materiais ferrosos endurecidos (principalmente aços e ferro fundido) e algumas superligas à base de cobalto e níquel (Lin et al., 1995). Existem evidências na literatura (Aspinwal et al., 1987) indicando que a usinagem de aços não endurecidos com PCBN não é econômica devido ao desgaste por difusão. No mercado americano existe a expectativa de uma taxa de crescimento de 40\% ao ano no período 1993-1998 no uso de materiais ultraduros (Abraham, 1995).

Pode-se observar na tabela 2.3 as características dos materiais ultraduros em comparação com outros materiais de ferramentas. 
Tabela 2.3 - Propriedades de alguns materiais de ferramenta (Abrão, et al., 1993).

\begin{tabular}{|c|c|c|c|c|}
\hline $\begin{array}{c}\text { Propriedades dos } \\
\text { materiais de } \\
\text { ferramenta }\end{array}$ & Metal Duro & $\begin{array}{c}\text { Alunina } \\
\text { reforçada com } \\
\text { Whisker }\end{array}$ & PCBN & PCD \\
\hline Composição típica & $\begin{array}{c}94 \mathrm{wt} \% \mathrm{WC}+ \\
6 \mathrm{wt} \% \mathrm{Co}\end{array}$ & $\begin{array}{c}75 \% \mathrm{Al}_{2} \mathrm{O}_{3}+ \\
25 \% \mathrm{SiC}\end{array}$ & $\begin{array}{c}98 \% \mathrm{CBN}+ \\
2 \% \\
\mathrm{AlB}_{2} / \mathrm{AlN}\end{array}$ & $\begin{array}{c}\text { PCD + 0- } \\
18 \% \mathrm{Co}\end{array}$ \\
\hline $\begin{array}{c}\text { Densidade }\left(\mathrm{g} / \mathrm{cm}^{3}\right) \\
\text { Dureza à } \\
\text { temperatura } \\
\text { ambiente }(\mathrm{HV})\end{array}$ & 14,8 & 3,7 & 3,1 & 3,4 \\
\hline $\begin{array}{c}\text { Dureza à } 1000{ }^{\circ} \mathrm{C} \\
(\mathrm{HV})\end{array}$ & 400 & 2000 & 4000 & $8000-10000$ \\
\hline $\begin{array}{c}\text { Resistência à fratura } \\
\left(\mathrm{MPa} \mathrm{m}^{1 / 2}\right)\end{array}$ & 10 & 8 & 1000 & 7,9 \\
\hline $\begin{array}{c}\text { Condutividade } \\
\left.\text { Térmica (W/m }{ }^{\circ} \mathrm{C}\right)\end{array}$ & 100 & 32 & 100 & 120 \\
\hline $\begin{array}{c}\text { Modulo de Young } \\
\left(\mathrm{kN} / \mathrm{mm}^{2}\right)\end{array}$ & 630 & 390 & 680 & 925 \\
\hline $\begin{array}{c}\text { Coeficiente de } \\
\text { expansão térmica } \\
\left(\mathrm{x} 10^{-6} / \mathrm{K}\right)\end{array}$ & $5-6$ & 6,4 & 4,9 & 3,8 \\
\hline
\end{tabular}

\subsubsection{1 - Diamante Policristalino (PCD)}

A ferramenta de diamante policristalino (PCD) é fabricada por dois processos: processo de sinterização a alta pressão e alta temperatura (HT/HP High Temperature/High Pressure) onde cristais de diamante e um elemento de liga são prensados a quente e, o processo de deposição química a partir da fase vapor (CVD) sobre um substrato, produzindo o recobrimento de diamante. Este último tem ganhado bastante espaço no mercado, pois neste processo é possível controlar a espessura da camada de diamante sintetizada sobre o substrato (Abraham, 1995), (Trava-Airoldi et al., 1994), (Trippe et al., 1994), (Hintermann et al., 1993). Outras vantagens são a produção em larga escala, baixo custo de produção, flexibilidade na forma da ferramenta com quebra cavaco e formas complexas de ferramenta (Takatsu, 1990). Vale ressaltar algumas características que tornam o diamante excelente como material para ferramenta de corte: 
- Extrema dureza / resistência ao desgaste abrasivo;

- Alta condutividade térmica / baixo coeficiente de expansão térmica;

- Quimicamente inerte / resistência a corrosão;

- Relativamente alta resistência mecânica (compressão);

- Coeficiente de atrito muito baixo (equivalente ao do teflon).

Comparado ao diamante monocristalino, possui as seguintes vantagens adicionais:

- O PCD é isotrópico e não tem plano preferencial de clivagem;

- O PCD sinterizado é disponível em diferentes classes, de acordo com o tamanho dos cristais de diamante (Steinmetz et al., 1993).

Sua principal desvantagem está no fato de não usinar materiais ferrosos, como o aço. Devido às altas temperaturas geradas no processo de usinagem ocorre a difusão do carbono do diamante para o aço, além da grafitização.

Em simples situação de desgaste abrasivo, o PCD é significativamente mais resistente ao desgaste que outros materiais de ferramenta de corte. O PCD é aproximadamente 10 vezes mais resistentes que o PCBN e 100 vezes mais resistente que o metal duro (Heath, 1989).

A granulação grossa de PCD proporciona uma maior vida a ferramenta, mas a granulação mais fina produz uma melhor qualidade de aresta e permite uma alta qualidade de acabamento superficial para ser produzida em materiais homogêneos. Para a maioria das aplicações , $10 \mu \mathrm{m}$ de tamanho médio de partícula deve ser considerado ferramenta de uso geral (Heath, 1989).

Para a fabricação da ferramenta o corte do blank de PCD em pedaços menores é normalmente feito por eletroerosão a fio. O próximo passo consiste na brasagem de um pequeno "blank" de forma apropriada em um alojamento no substrato de aço rápido ou de metal duro. Em geral a brasagem da ferramenta de PCD é feita com uma liga a base de prata com baixo ponto de fusão. Um grande cuidado deve ser tomado para não sobre-aquecer o "blank" de PCD; o sobreaquecimento pode levar o diamante a voltar para forma de grafite. A retificação do flanco da ferramenta remove os danos produzidos pelo corte feito pela eletroerosão a fio e gerar a geometria de corte requerida. 


\subsubsection{2 - Carbeto de Boro Cúbico Policristalino (PCBN)}

Carbeto de boro cúbico é o material mais duro, depois do diamante, tendo sido sintetizado com sucesso pela primeira vez em 1957 pela General Eletric Co., USA. É um material inteiramente artificial, não existindo na natureza. Sua sintetização seguiu do desenvolvimento feito para a sintetização do diamante. Tipicamente, o pó de CBN é fabricado expondo o nitreto de boro hexagonal juntamente com um catalizador a uma pressão e temperatura extremamemte altas (mínimo de $40 \mathrm{Kbar}$ e $1500^{\circ} \mathrm{C}$ respectivamente) (Abrão et al., 1993).

Os primeiros "blanks" comerciais de ferramentas de PCBN foram produzidos também pela General Eletric Co. em meados dos anos 1970 sob o nome comercial de Borazon Compact ${ }^{\mathrm{TM}}$ e constituía-se de uma camada de 0,5 mm de PCBN sustentada por um substrato de metal duro para proporcionar resistência adicional e ajudar na fabricação da ferramenta. Atualmente, uma variedade de produtos de PCBN é fabricada por um limitado número de companhias em todo o mundo.

Os produtos de PCBN podem ser caracterizados pela quantidade de CBN e as segundas fases, as quais podem ser um metal (liga $\mathrm{NiCo}$ ), um carbeto ( $\mathrm{TiC}$ ou WC) ou uma cerâmica ( $\mathrm{TiN}, \mathrm{AlB}_{2} / \mathrm{AlN}$ ) cujas proporções podem variar de aproximadamente 5 à $70 \%$. A Segunda fase pode agir como uma fase ligante, como no metal duro convencional, mas serve para preencher a porosidade da estrutura policristalina e em alguns casos proporcionar uma condutividade elétrica para ajudar na fabricação das ferramentas. A fase secundária pode também estender a amplitude de aplicações do PCBN especialmente para as operações de acabamento. A maioria dos produtos tem um tamanho de grão entre 1-3 $\mu \mathrm{m}$ (Abrão, et al., 1993).

Comparado ao diamante sua dureza é aproximadamente a metade e a condutividade térmica é $65 \%$ daquela do diamante. Tem estabilidade térmica até aproximadamente $1300^{\circ} \mathrm{C}$ e passa a ser reativo quimicamente a partir de $1050^{\circ} \mathrm{C}$ (DeVries, 1972). Em comparação com as cerâmicas possui menor taxa de desgaste, em certas aplicações (Rigaut et al., 1994).

Diferentemente do PCD, o PCBN apresenta um grande número de diferentes formulações. Cada fabricante usa diferentes materiais de segunda fase, 
distribuição do tamanho de partículas e concentração de grãos de CBN. Portanto, não é fácil generalizar sobre propriedades mecânicas, técnicas de fabricação, e performance de usinagem das várias classes. Entretanto, duas amplas categorias de aplicação podem ser definidas (Heath, 1989):

- Usinagem de desbaste de materiais ferrosos endurecidos, particularmente ferros fundidos endurecidos com uma faixa de dureza de 45 à $65 \mathrm{HRC}$, e com profundidade de usinagem entre $0,5 \mathrm{~mm}$ e $8,0 \mathrm{~mm}$.

- Usinagem de acabamento de componentes endurecidos, tipicamente aços ferramenta ou ferros fundidos endurecidos superficialmente. Com profundidade de usinagem abaixo de $0,5 \mathrm{~mm}$, tipicamente $0,2 \mathrm{~mm}$.

A usinagem de desbaste de materiais ferrosos endurecidos requer ferramentas com alta porcentagem de $\mathrm{CBN}$, enquanto operações de acabamento são realizadas mais efetivamente quando a porcentagem de CBN é menor.

Para alguns materiais de peça, o aumento da velocidade de corte resulta no aumento da vida da ferramenta, para uma determinada faixa de velocidades (Heath, 1989) . Para outros materiais, tais como ferro fundido fundido martensítico endurecido, o aumento da velocidade de corte resulta em diminuição da vida da ferramenta.

O PCBN é produzido na forma de um grande "blank", o qual é então cortado em peças menores, antes sendo estabelecida a forma desejada. Entretanto, o corte de PCBN com alta porcentagem de $\mathrm{CBN}$ requer corte a laser, e não eletroerosão a fio, uma vez que o CBN tem uma condutividade elétrica muito baixa. Um PCBN no formato de camadas (sobre WC) é eletricamente condutivo e pode ser cortado por eletroerosão a fio.

As ferramentas de corte de PCBN, estão disponíveis na forma de "blanks" com uma camada de PCBN sobre outra de carbeto, ou então, na forma de insertos prontos para o uso em suportes padronizados. PCBN no formato de camadas é cortado em peças pequenas e brasados substituindo a aresta de corte de insertos de metal duro indexáveis. (Heath, 1989).

Recobrir uma aresta de corte com CBN é uma alternativa ao processo de sintetização, entretanto, o desenvolvimento deste processo tem sido menor do que a cobertura com diamante. As principais razões são a dificuldade na formação do filme de PCBN e a inadequada resistência de adesão (Takatsu, 1990). 


\section{3 - Desgaste em ferramentas de corte}

Materiais metálicos possuem irregularidades em sua superfície, na forma de picos e vales. $\mathrm{Na}$ interface entre dois materiais, são criadas minúsculas áreas de contato. Quando existe movimento entre eles ocorre perda de material de ambas as superfícies, normalmente na de menor dureza a perda é mais pronunciada. $\mathrm{Na}$ usinagem dos metais a ação de corte e o atrito do cavaco contra a ferramenta aumenta a temperatura na interface, o que acelera os processos físicos e químicos associados ao desgaste da ferramenta. Com o desgaste, a geometria da ferramenta tende a mudar. Esta mudança de geometria terá influência na força de corte, na potência consumida, no acabamento superficial obtido, na acuracidade dimensional e na estabilidade dinâmica do processo (com a ferramenta gasta aparece "chatter" no processo, que são vibrações livres).

Para uma ferramenta de corte, a perda de material é indesejável e deve ser minimizada, portanto é conveniente conhecer como se processa o desgaste, a fim de evitá-lo. Como no processo de usinagem existe uma geração intensa de calor, a temperatura tem grande importância no desgaste da ferramenta. A temperatura do material da ferramenta na zona onde ocorre o desgaste é determinada pela diferença entre a taxa de energia térmica gerada e taxa de energia térmica dissipada. A dissipação da energia térmica é uma função das propriedades termocondutivas do material da ferramenta e do material da peça (Kendall, 1989). O desenvolvimento e a seleção básica de materiais de ferramenta são baseados na sua habilidade de manter a dureza, tenacidade e a estabilidade química a altas temperaturas. Mesmo as melhores ferramentas podem ter suas propriedades modificadas com o aumento da temperatura.

\subsection{1 - Mecanismos de desgaste}

O desgaste das ferramentas de corte ocorre devido a determinados mecanismos de desgaste, que se manifestam de formas distintas. Podem ser classificados de acordo com a tabela 2.4 (Shaw, 1971). 
Tabela 2.4 - Mecanismos de desgaste.

\begin{tabular}{|l|l|}
\hline Tipos & Características \\
\hline Adesivo & Soldagem de superfícies ásperas \\
\hline Abrasivo & Ação de corte de partículas endurecidas \\
\hline Químico & Difusão de elementos químicos \\
\hline Fadiga da superfície & Crescimento gradual de trincas superficiais \\
\hline Oxidação & Formação de óxidos duros \\
\hline
\end{tabular}

Dificilmente o desgaste de uma ferramenta será proveniente de apenas um único mecanismo, mas sim de uma combinação entre eles. Segue abaixo a descrição dos mecanismos de desgaste mais importantes.

Desgaste adesivo - Este mecanismo acontece de maneira semelhante à formação da aresta postiça. Sucessivas camadas do material da peça se soldam sobre a superfície da ferramenta devido à baixa temperatura e alta pressão, sendo posteriormente endurecidas devido ao encruamento. Esta estrutura rompe-se, por cisalhamento, e arranca pequenos pedaços da ferramenta ou causa a fratura da mesma (Modern,1994) (Dixon et al., 1985). Tal desgaste é mais pronunciado em baixas temperaturas com elevadas pressões sobre a aresta de corte. Pode também ser acelerado dependendo da afinidade química entre os materiais da peça e da ferramenta.

Desgaste abrasivo - Ocorre quando partículas abrasivas muito duras presentes na superfície da peça, ou do cavaco, (como carbetos) são pressionadas contra uma das superfícies da ferramenta (Cupini et al., 1993), (Ohtani et al., 1988) (Yamamoto et al., 1994). A capacidade do material da ferramenta de resistir a este mecanismo de desgaste está ligada à sua dureza a alta temperatura e ao ponto de fusão da mesma. Com o aumento da temperatura a dureza do material da ferramenta tende a diminuir, e isto acontece quando aumenta-se a velocidade de corte e o avanço. Consequentemente a temperatura da aresta de corte aumenta, podendo este efeito ser atenuado pelo uso de uma ferramenta com alta condutividade térmica. Essa perda de dureza proporciona o arrancamento de material da ferramenta pelas partículas duras presentes no material que esta sendo usinado. Este é, resumidamente, o que provoca o desgaste abrasivo. Pode-se fazer uma analogia com o processo de retificação, onde o rebolo com suas partículas 
abrasivas, retira material da peça. Na usinagem convencional porém, a situação é inversa, o cavaco faz o papel do rebolo (sempre afiado) e a ferramenta o papel da peça.

Desgaste químico - Está ligado à afinidade química entre o material da ferramenta e o material da peça e a alta temperatura e pressão. Altas temperaturas alcançadas durante o corte, possibilitam a difusão de elementos químicos entre a peça e a ferramenta mudando as características de ambas. A forma mais comum é a difusão dos elementos de liga ou do carbono da peça para a ferramenta e viceversa (Xiao, 1990), (Klimenko et al., 1992). Isto resulta na formação de cratera na superfície de saída da ferramenta. Um exemplo deste mecanismo é a grafitização das ferramentas de diamante, quando submetidas a altas temperaturas (König et al., 1993).

Desgaste por fadiga - Pode-se manifestar de duas maneiras: fadiga mecânica - a ferramenta falha por seguidos esforços de tração e de compressão na direção da velocidade de corte; fadiga térmica - a ferramenta é sujeita a ciclos térmicos (aquecimento seguido de resfriamento). Ambos provocam microtrincas. Normalmente estes dois tipos de fadiga são causados pelo corte intermitente (ex. fresamento, torneamento de um eixo com ranhuras).

Oxidação - A alta temperatura mais o oxigênio presente no ar significa oxidação para a maioria dos materiais usinados. Tungstênio e cobalto formam um filme de óxido poroso no cavaco, os quais são mais frágeis, porém alguns óxidos como o óxido de alumínio são muito mais resistentes e duros. O desgaste normalmente ocorre na altura da profundidade de usinagem, onde a largura do cavaco termina.

\subsection{2 - Tipos de desgaste}

As ferramentas de corte sofrem vários tipos de desgaste, que vão depender principalmente da relação de dureza entre peça e ferramenta, e das condições de corte. Também estão relacionados com os mecanismos de desgaste vistos no item anterior. Os tipos mais importantes são citados a seguir na tabela 2.5, junto com os mecanismos de desgastes predominantes. 
Desgaste de flanco - Durante a usinagem a superfície de folga da ferramenta é submetida a um contato com a superfície recém usinada. Este contato conduz a um desgaste progressivo, conhecido como desgaste de flanco, vide figura 2.8. O mecanismo de desgaste predominante é o abrasivo. As partículas duras do material da peça, que permanecem sobre a superfície usinada, são pressionadas contra o flanco da ferramenta atuando como um rebolo. Quando o desgaste de flanco é acentuado, pode ocorrer um aumento de temperatura levando ao desgaste químico, ou oxidação. A deterioração do flanco da ferramenta diminui a qualidade da textura superficial e afeta a dimensão da peça em determinadas operações.

Para minimizar este desgaste é indicado o PCBN (materiais ferrosos), o PCD (materiais não ferrosos) e as cerâmicas reforçadas pois todos possuem elevada dureza, seguido dos carbetos recobertos. Uma geometria de ferramenta adequada também pode prolongar a vida da ferramenta (Shintani et al., 1989), (Shintani et al., 1989).

Desgaste de sulco - Pode aparecer na aresta principal, na altura aproximadamente da profundidade de usinagem, conforme mostrado na figura 2.8. É muito comum aparecer quando se usinam materiais com camada endurecida ou aços de alta resistência a quente, por exemplo ligas de titânio. O mecanismo de desgaste dominante é o adesivo seguido pela oxidação. Um desgaste de sulco excessivo reduz a qualidade da textura superficial no acabamento e eventualmente enfraquece a aresta de corte, aumentando o risco de falha catastrófica. Nos casos onde o desgaste de sulco é causado pela oxidação o PCBN e a cerâmica são as melhores opções. Quando o mecanismo é adesivo o metal duro é mais recomendado.

Desgaste de cratera - Ocorre como resultado do atrito desenvolvido pelo fluxo de cavaco sobre a superfície de saída da ferramenta. A máxima temperatura na superfície da ferramenta ocorre a uma pequena distância da aresta de corte, fornecendo as condições para o desgaste de cratera (figura 2.8), dominada pelo mecanismo de desgaste químico (difusão). Em materiais de ferramentas muito duros, tal como a cerâmica, para a qual altas velocidades de corte são normalmente usadas, esses mecanismos de oxidação e químico podem ser responsáveis pela maioria do desgaste (Kendall, 1989). A cratera também pode ser 
formada pela ação de partículas endurecidas, de acordo com o mecanismo de desgaste abrasivo. Excessivo desgaste de cratera muda a geometria da aresta de corte e pode influenciar na formação do cavaco, mudando o ângulo do plano de cisalhamento, a direção das componentes da força de usinagem e também enfraquece a aresta de corte. As cerâmicas apresentam uma boa resistência por serem inertes, seguidas pelo PCBN.

Tabela 2.5 - Tipos de desgaste.

\begin{tabular}{|l|l|}
\hline Tipos & Mecanismos predominantes \\
\hline Desgaste de flanco & Abrasão e químico \\
\hline Desgaste de sulco & Adesão e oxidação \\
\hline Desgaste de cratera & Químico e abrasão \\
\hline Deformação plástica & Alta temperatura e alta pressão \\
\hline Lascamento & Fadiga \\
\hline Falha catastrófica & Fadiga (muito severa) \\
\hline Desgaste em forma de pente & Fadiga \\
\hline Aresta postiça & Adesão \\
\hline
\end{tabular}

Deformação plástica - É o resultado da combinação de alta temperatura com alta pressão sobre a aresta de corte. Altas velocidades de corte, avanço elevado e o material da peça endurecido são os maiores responsáveis. Para que a ferramenta consiga resistir, ter alta dureza a quente, é primordial. A formação de uma saliência sobre a aresta de corte terá efeito sobre a temperatura de corte, a geometria da ferramenta, o fluxo do cavaco e o desgaste de flanco. O PCBN é a melhor opção para materiais ferrosos e o PCD para os não ferrosos.

Lascamento - Pode ocorrer ao longo da aresta principal de corte. Tais lascamentos aparecem mais frequentemente quando a aresta de corte remove o cavaco intermitentemente. Isto resulta em ciclos de impacto e de carregamento térmico na aresta de corte. Estes dois estados de carregamento cíclico podem iniciar pequenas trincas e então propagar estas trincas ou outras trincas residuais para formar lascas. $\mathrm{O}$ mecanismo de desgaste dominante é a fadiga (por impacto ou térmica). Este tipo de desgaste empobrece a textura superficial e aumenta o 
desgaste de flanco. Neste tipo de desgaste o metal duro deve ser empregado em classes mais tenazes.

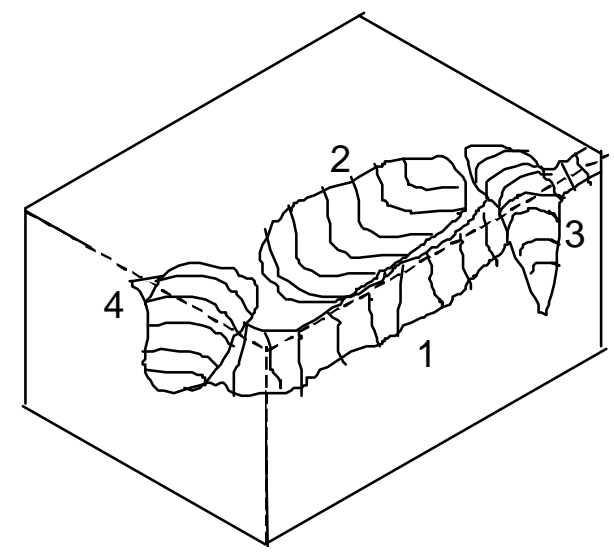

1- Desgaste de flanco

2- Desgaste de cratera 3- Desgaste de sulco na aresta principal de corte 4- Desgaste de sulco na aresta secundária de corte

Figura 2.8 - Alguns dos tipos de desgaste mais comuns.

Falha catastrófica - Pode ser subdividida em dois modos de falha, por excesso de temperatura ou excesso de carga.

Quando a temperatura é muito elevada a aresta de corte tem a dureza diminuída e o material flui plasticamente, devido às tensões desenvolvidas pela força de corte. A ferramenta fica com o aspecto da figura 2.9, onde aparece uma depressão na aresta de corte e uma saliência sobre a superfície de folga. O ângulo de folga é reduzido para um pequeno valor ao longo do flanco da ferramenta. Durante este período as camadas do material da ferramenta em contato com a superfície recém usinada são destacadas. Uma grande área de contato é iniciada resultando em substancial aumento do atrito, aumentando rapidamente a temperatura. A ferramenta perde a estabilidade da forma e falha rapidamente, devido ao amolecimento.

A outra maneira de uma falha repentina é um excesso de força agindo sobre a ferramenta de corte causando a falha imediata da aresta de corte por falta de resistência mecânica da ferramenta. Existe também a falha devido à fadiga por impacto, aparecendo o lascamento e o desenvolvimento de trincas ao longo da aresta de corte, terminando com a falha catastrófica. Pode-se dizer que o mecanismo de desgaste é a fadiga, mas de uma forma muito severa associado com a fratura. Quando este tipo de desgaste é observado, o PCBN e o PCD podem ter um bom desempenho seguido dos carbetos recobertos. 


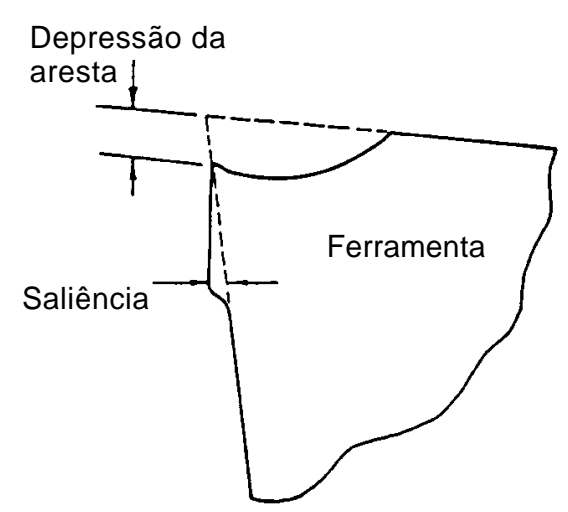

Figura 2.9 - Depressão e saliência sobre a aresta de corte devido a deformação plástica.

Desgaste em forma de pente - Ocorre devido ao ciclo térmico, o qual a ferramenta é submetida durante o corte intermitente (especialmente no fresamento). Trincas são formadas perpendicularmente à aresta principal de corte e pequenos pedaços do material da ferramenta são arrancados. A aplicação de fluido de corte, em certos casos, pode ser prejudicial, pois aumenta a amplitude da variação da temperatura. Os materiais de ferramentas recomendados nos casos onde este tipo de desgaste aparece são o PCD e o PCBN.

Aresta postiça - Depende, principalmente, da velocidade de corte e da afinidade química dos materiais da peça e da ferramenta. Aparece normalmente em baixas velocidades de corte e com a alta pressão de corte, soldando o material do cavaco à ferramenta. A aresta postiça arranca material da ferramenta quando se rompe por cisalhamento produzindo o desgaste. Quando formada, também muda a geometria da ferramenta, alterando a direção da força de usinagem, o ângulo de cisalhamento e o ângulo de saída. As temperaturas e as velocidades de corte onde ocorre a aresta postiça são bem definidas e assim podem ser evitadas. O acabamento superficial é bastante prejudicado com a aresta postiça. Quando o material da peça possui elementos químicos que reagem com facilidade a cerâmica é uma boa opção. O metal duro recoberto também pode ser usado. 


\subsection{3 - Exemplos de associações entre tipos e mecanismos de desgaste}

Algumas associações de mecanismos e tipos de desgaste são dependentes do material da ferramenta, do material da peça e de atros fatores. A seguir são mostrados alguns exemplos de associações.

$\mathrm{O}$ recobrimento de aço rápido com nitreto de titânio (TiN) promove uma maior resistência ao desgaste de flanco (Lim et al., 1995). A aplicação de cobertura TiN sobre insertos de aço rápido expande drasticamente os limites de avanço e velocidade de corte dentro dos quais a taxa de desgaste de flanco é aceitável. Entretanto, o grau de melhoramento depende fortemente das condições de usinagem usadas. Foram encontrados os seguintes mecanismos de desgaste nas ferramentas de aço rápido recobertas com TiN (Lim et al., 1995):

- Micro abrasão - produzindo uma superfície relativamente lisa com partículas de carbeto.

- Micro abrasão - produzindo uma superfície com partículas de carbeto e furos na superfície da ferramenta.

- Lascamento - resulta na perda de material da ferramenta.

Ferramentas de metal duro à base de carbeto de tungstênio, carbeto de titânio e cobalto (WC-TiC-Co) usadas na usinagem de aço inoxidável (material de difícil usinagem) revelaram como principais mecanismos de desgaste da ferramentas os mecanismos abrasivo, adesivo e químico. $\mathrm{O}$ desgaste adesivo tem maior relevância, pois na interface cavaco-ferramenta estão presentes tensões normais muito altas, condição ideal para forte adesão (Qi et al., 1996).

A formação de uma camada aderida na superfície de saída da ferramenta muda o comportamento do desgaste:

- Reduz o contato físico entre a ferramenta e o cavaco, diminuindo o desgaste abrasivo e o adesivo;

- Muda o modelo de difusão dinâmica (cavaco/ferramenta) para quase estático (ferramenta/camada aderida). Como resultado diminui a taxa de difusão.

Inclusões presentes no material da peça funcionam como fonte de micro trincas na zona de cisalhamento primária provocando a diminuição da temperatura de corte. Mas também contribuem para a abrasão. 
No torneamento com ferramenta de diferentes classes de cermets e diferentes materiais de peça observou-se que os ciclos térmico e de impacto mecânico afetam a formação de microtrincas na aresta de corte. Tais microtrincas causam a formação do desgaste de sulco.

Em cermet à base de $(\mathrm{Ti}(\mathrm{CN}))$ os mecanismos de desgaste predominantes são: abrasão na superfície de saída e de flanco, adesivo na superfície de saída. Também foram encontradas trincas na superfície de saída, deformação plástica e, ocasionalmente microtrincas na aresta de corte (Thoors et al., 1993).

Observou-se também que o material da peça influencia no comportamento do desgaste (Thoors et al., 1993). Além disso, o desgaste não é somente afetado pela combinação de velocidade de corte e avanço, mas também pelo ângulo de saída da ferramenta e aplicação de refrigerante (Tönshoff et al., 1994).

Para materiais cerâmicos, em geral, os principais mecanismos de desgaste são (Gueroult et al., 1994): o polimento, a abrasão, a formação de trincas superficiais por divisão, a formação de trincas superficiais intergranulares e microtrincas.

Deformações na ferramenta podem ocorrer, sendo os efeitos do fluxo plástico responsáveis pelo início e propagação de trincas, promovendo o surgimento do desgaste de flanco.

$\mathrm{Na}$ grande maioria dos trabalhos encontrados na literatura técnica a cerâmica é considerada inerte quimicamente. No entanto, Vleugels et al., 1995 encontraram evidências de desgaste químico, no flanco da ferramenta de cerâmica (YSiAlON), quando torneando o aço 50NiCr13. Para esta mesma ferramenta foi encontrado o desgaste de cratera, também atribuído ao mecanismo de desgaste químico. Masuda et al., 1994 encontraram desgaste de cratera para ferramentas cerâmicas em baixas velocidades de corte, onde a abrasão torna-se predominante. O mecanismo abrasivo depende dos seguintes parâmetros: dureza do material, carga normal, partículas abrasivas afiadas (Evans et al., 1980).

O comprimento de contato do cavaco tem ligações com as tensões de corte (Pashby et al., 1993). Avaliações de tensões de tração induzidas termicamente, feitas por método de elementos finitos, sugerem que elas excedem a resistência do $\mathrm{Al}_{2} \mathrm{O}_{3}$ (Lo Casto et al., 1993). 
Em condições severas de usinagem, como no torneamento de material endurecido, a alta força específica e alta temperatura em uma pequena área de contato entre ferramenta e peça, são fatores que aceleram o desgaste da ferramenta (Tönshoff et al., 1995). No fresamento do aço temperado AISI H13 a vida das ferramentas de cerâmica não apresentaram bons resultados ficando abaixo da vida das ferramentas de metal duro. O lascamento foi o principal mecanismo de desgaste das ferramentas de cerâmica, enquanto um desgaste de flanco regular predomina nas ferramentas de metal duro para esta aplicação. O reflexo deste comportamento pode ser observado no acabamento superficial, onde uma rugosidade menor foi obtida para as ferramentas de metal duro. Novamente, o lascamento apresentado pelas ferramentas de cerâmica é responsável por este resultado (Silva et al., 1997).

Para torneamento de acabamento em material endurecido, as ferramentas de PCBN com quantidade de CBN entre 50 e $75 \%$ são mais resistentes ao desgaste que as ferramentas com alta quantidade de CBN ( 90\%). A interação entre o ligante da ferramenta e o material de peça, a microestrutura da peça e o tamanho de grão do CBN têm mostrado ser fatores importantes no desgaste da ferramenta (Davies et al., 1996).

No torneamento de acabamento do aço de rolamento endurecido (AISI 52100), os melhores resultados com relação a vida da ferramenta e acabamento superficial são obtidos quando usando ferramentas com baixa quantidade de PCBN e ferramentas de cerâmicas mistas (a cerâmica mista é geralmente constituída de uma matriz $\mathrm{Al}_{2} \mathrm{O}_{3}$ e $30 \%$ ou mais de $\mathrm{TiC}$ ou TiN prensados a quente até a máxima densidade). Quando em torneamento de desbaste, a baixa quantidade de PCBN produz melhores resultados nas mais baixas velocidades de corte, enquanto que a alta quantidade de PCBN provou ser mais adequada quando as velocidades de corte foram aumentadas (Abrão et al., 1997).

Quando trata-se de usinagem de alta velocidade o desgaste de PCBN é devido ao mecanismo de difusão química. O pico de temperatura parece ser governado pela natureza da formação do cavaco, o qual pode mudar de contínuo (ferro fundido com matriz ferrítica) para descontínuo (ferro fundido com matriz perlítica), sendo o último o que produz menor desgaste no caso do ferro fundido (Rai, 1993). 
O desgaste de ferramentas de diamante monocristalino também é influenciado pelo material da peça. Um trabalho específico (Oomen et al., 1992), feito com diamante monocristalino, revelou que o tipo de desgaste depende do material da peça, entre outros fatores. $\mathrm{Na}$ usinagem de alumínio houve arredondamento da aresta de corte; com o cobre desgaste de cratera; níquel desgaste de cratera e sulcos.

Na usinagem de MMC (AA2618 + 15vol.\% SiCp), micrografias revelaram que o principal mecanismo de desgaste das ferramentas de PCD é a abrasão. O desgaste se mostrou sensível ao aumento da velocidade de corte, elevando o desgaste tanto para furação quanto para fresamento de faceamento (Coelho, 1994).

Como foi descrito anteriormente, a velocidade de corte tem uma importância relevante no processo de desgaste e pode-se dizer que:

- A transição de um mecanismo de desgaste dominante para outro é mais sensível à velocidade de corte do que ao avanço (Lim et al., 1995).

- Para baixas velocidades de corte o desgaste mecânico (onde só existe a ação de partículas duras) predomina, sendo o desgaste abrasivo do material da ferramenta mais evidente.

- Em altas velocidades de corte o desgaste térmico e mecânico predominam. Os mecanismos físicos que são responsáveis pela produção gradual do desgaste dependem da temperatura de corte. Para cada combinação de material de ferramenta e material de peça, a transição entre regimes de desgaste é determinada por propriedades químicas e mecânicas do sistema peçaferramenta. Em altas velocidades de corte, onde as temperaturas podem subir acima de $1000^{\circ} \mathrm{C}$, a estabilidade química do material da ferramenta com relação a elementos presentes na peça torna-se um contribuidor muito importante para o desgaste. A solubilidade química do material da ferramenta na peça aumenta exponencialmente com a temperatura (Rai, 1993).

\section{4 - Emissão acústica na usinagem dos metais}

O termo emissão acústica (EA) refere-se, principalmente, a ondas de tensões elásticas geradas como resultado de uma rápida liberação da energia de 
deformação dentro do material (Kannatey-Asibu, et al., 1981). Isso ocorre devido ao rearranjamento da estrutura interna do material. As ondas de tensão geradas pelo rearranjamento da estrutura podem produzir deslocamentos sobre a superfície do material os quais são detectados pela conversão destes em sinais elétricos usando um transdutor piezoelétrico (Kannatey-Asibu, et al., 1981). O sinal de emissão acústica detectado no sensor é um efeito médio de um grande número de fontes de deslocamento operando no material (Rangwala, et. al., 1991).

As fontes da emissão acústica vêm de processos capazes de realizar mudanças na estrutura interna do material tais como: movimento de discordâncias, difusão direcional lenta e deslizamento da fronteira de grãos, os quais resultam em deformação plástica, transformações de fase, união de lacunas, descoesão de inclusões e fraturas (Kannatey-Asibu, et al., 1981). Destes processos, somente a deformação plástica e a fratura são de alguma significância no corte dos metais. A deformação plástica é considerada a fonte de emissão acústica mais importante .

Os mecanismos de deformação requerem a aplicação de tensão e conseqüente consumo de energia. Geralmente, a energia aplicada resulta em energia elástica, a qual é armazenada em trabalho plástico de deformação o qual é irrecuperável. O trabalho plástico de deformação ocorre principalmente pelo movimento de discordância que é a fonte de emissão acústica. O movimento de uma discordância requer o fornecimento de uma certa quantidade de energia para vencer as forças de arraste. Com a deformação, a energia aplicada na superação das forças de arraste é liberada. Uma onda de tensão é produzida no material, a qual produz deslocamentos sobre a superfície do material. Tais deslocamentos podem ser detectados por um sensor de emissão acústica.

Ondas de emissão acústica viajam em velocidades específicas em um dado meio e esta propriedade pode ser usada na localização das fontes de sinais de emissão acústica da mesma forma como é feito na sismologia onde se localiza a fonte de terremotos, pela técnica conhecida como triangulação.

Um dos maiores problemas na aplicação da emissão acústica é representado pela análise e interpretação dos sinais emitidos, devido à aleatoriedade do sinal de emissão acústica gerada no processo. Um sinal de emissão acústica contêm muitas freqüências e não pode ser explicitamente descrito por relações matemáticas (Teti, et al., 1989). 
Em sua forma primitiva, as ondas são basicamente senoidais brutas. Entretanto, no curso de propagação, eles freqüentemente sofrem consideráveis mudanças através da dispersão por defeitos estruturais, múltiplas reflexões em interfaces e refrações quando existe uma mudança de meio ao longo do caminho. Todos esses fatores modificam consideravelmente a forma da onda pela mudança de fase, atenuação da amplitude e repetição da onda (através da reflexão) chegando a uma forma final de onda que é descrita como bastante aleatória em relação à onda senoidal bruta original, tornando a identificação da fonte do sinal uma tarefa bastante difícil (Kannatey-Asibu, et al., 1981). Consequentemente, técnicas estatísticas são freqüentemente usadas para na análise do sinal de emissão acústica. Uma ampla variedade de técnicas podem ser utilizadas de acordo com o tipo de sinal de emissão acústica, a instrumentação experimental usada e as preferências pessoais do pesquisador (Kannatey-Asibu, et al., 1981), (Teti, et al., 1989). Entre as técnicas mais comuns estão:

- Contagem e taxa de contagem - é a contagem dos sinais cuja amplitude excede um limite de voltagem ou a taxa de ocorrência de sinais excedendo o limite;

- Análise da distribuição da amplitude - é uma indicação do número de sinais para os quais a amplitude se encontra dentro de uma faixa pré definida.

- Espectro de freqüência - mostra a contribuição de cada componente de frequiência para a formação do sinal original;

- Função de autocorrelação - envolve a comparação de um sinal de forma de onda $f(t)$ contra a versão atrasada da mesma forma de onda $f(t-\tau)$;

- Valor RMS (Root Mean Square) do sinal - é a medição da intensidade de energia do sinal. O RMS faz a retificação do sinal e calcula a sua média quadrática em intervalos de tempo determinados. A taxa com a qual a energia é transmitida pelo sinal pode ser diretamente correlacionada com a taxa de energia gerada pela fonte de emissão acústica. A taxa de energia do sinal de emissão acústica depende da taxa de deformação, da tensão aplicada e do volume de material envolvido no processo de deformação (Teti, et al., 1989).

Existem três áreas de interesse no processo de corte, com respeito a geração da emissão acústica (Kannatey-Asibu, et al., 1981).

- A zona primária de deformação ( plano de cisalhamento); 
- A zona secundária de deformação (interface cavaco/ferramenta);

- A zona terciária (interface superfície de folga da ferramenta/peça).

As atividades nestas três zonas constituem no deslizamento com atrito ou de deformação plástica ou ambos. As zonas do plano de cisalhamento e a interface cavaco/ferramenta contribuem aproximadamente com a mesma quantidade de energia para o sinal de emissão acústica total (Teti, et al., 1989).

Dados experimentais revelam que a emissão acústica depende do material da peça, pois os materiais possuem resistências ao cisalhamento diferentes (o aço apresenta um nível de emissão acústica maior que o alumínio) (Kannatey-Asibu et al., 1981).

A emissão acústica tem sido investigada como uma alternativa para monitoramento on-line de desgaste de ferramentas no corte dos metais. Estudos iniciais a este respeito têm enfatizado: (a) relações empíricas entre o sinal de emissão acústica e o desgaste de flanco e (b) relações entre a emissão acústica e os parâmetros de corte (onde boa correlação tem sido encontrada entre o sinal de emissão acústica, taxa de deformação e velocidade de corte) (Kannatey-Asibu et al., 1981).

Com o desgaste da ferramenta, isto é, aumento do comprimento médio da interface flanco da ferramenta/peça, a amplitude da energia de emissão acústica gerada nesta região aumenta. Quando a ferramenta está fortemente desgastada, esta fonte de emissão acústica torna-se dominante. Esta é a base dos trabalhos feitos em monitoramento de desgaste de ferramenta.

No corte oblíquo do aço SAE 1018 com ferramenta de metal duro, Teti et al., 1989 concluiram que a energia da emissão acústica aumenta com a velocidade de corte e diminui com o ângulo de saída da ferramenta. Enquanto que a influência da profundidade de usinagem e do avanço sobre o valor RMS do sinal de emissão acústica mostrou-se relativamente pequena podendo ser negligenciada.

Quando o processo torna-se idealizado (aresta de corte afiada, pequeno ou nenhum atrito), a sensibilidade do sinal da emissão acústica para as variáveis avanço e profundidade de usinagem, além da velocidade de corte, aumentam. Isto foi observado no estudo de Pan et al., 1986 usando ferramentas de diamante no torneamento de duas ligas de alumínio e do latão de corte fácil. 
Teti et al., 1989 também encontraram, uma forte dependência da energia de emissão acústica sobre a velocidade de corte, com significativa dependência do avanço e da profundidade de usinagem em condições de corte quase "ideais".

O sinal de emissão acústica (RMS) parece mais influenciado pelas condições de usinagem dentro de condições "ideais". Por outro lado dentro de condições convencionais, mostra pequena dependência previsível sobre o avanço e a profundidade de usinagem (Teti et al., 1989).

Em velocidades de corte menores, a emissão acústica gerada no plano de cisalhamento tem freqüências mais baixas devido às menores taxas de deformação. Com o aumento da velocidade (e correspondentemente, a taxa de deformação) a emissão acústica do plano de cisalhamento muda para frequiências mais altas. $\mathrm{Na}$ interface cavaco/ferramenta os efeitos combinados do encruamento, taxa de deformação e temperatura de corte devem de ser considerados. As altas taxas de deformação na zona secundária de cisalhamento e o alto nível de encruamento do material do cavaco produzem um sinal de emissão acústica de alta frequiência. Contudo, com o aumento da velocidade de corte, a temperatura da interface cavaco/ferramenta também aumenta. $\mathrm{O}$ efeito da temperatura torna-se significativo o bastante para compensar o efeito do maior nível de encruamento e da maior taxa de deformação, produzindo um sinal de emissão acústica com freqüências mais baixas .( Rangawala et al., 1991).

Os resultados experimentais encontrados por Rangawala et al., 1991 indicam que o espectro contido no sinal de emissão acústica muda em direção a uma frequiência mais alta quando a velocidade de corte aumenta. Eventualmente, contudo, quando a velocidade recebe um aumento adicional provoca uma mudança na energia do sinal para frequiências mais baixas. Isto é atribuído aos efeitos do amolecimento térmico do material da ferramenta associado com o aumento da velocidade, os quais causam a mudança para baixas frequiências na emissão acústica gerada na interface cavaco/ferramenta. Os efeitos do avanço sobre a frequiência média não mostram uma clara tendência nas velocidades mais altas, onde é observado que um aumento do avanço causa uma queda da frequiência média. Foi também observado que a frequiência média aumenta com o comprimento de contato cavaco/ferramenta e isto foi atribuído à maior quantidade de cavaco deslizando em um comprimento de contato maior. 
Apesar da deformação plástica ser a maior fonte de emissão acústica, em trabalho realizado a respeito da detecção de fraturas durante o corte dos metais, Naneeda et al., 1979 conseguiram monitorar a geração de micro-trincas no processo de separação do cavaco com a ajuda da emissão acústica gerada pela fratura do cavaco. O emprego da emissão acústica na usinagem está ligado a tentativa de monitoramento das operações de usinagem "on line" 


\section{0 - TRABALHO EXPERIMENTAL}

Este capítulo trata da investigação experimental sobre o emprego da operação de fresamento de topo em aços ferramenta endurecidos usando ferramentas de PCBN e Metal Duro (MD). Além disso mede-se o valor RMS da EA durante o fresamento investigando-se sua relação com as condições de usinagem.

\section{1 - Equipamentos}

A usinagem foi realizada em um centro de usinagem horizontal VARGA $\mathrm{CNC}$, modelo MFH 40. A rotação do eixo árvore varia de 50 à $5.000 \mathrm{rpm}$, a potência do motor do eixo árvore é de $10,5 \mathrm{KW}$, o curso de cada carro (x, y e z) é de $400 \mathrm{~mm}$. A máxima velocidade de corte possível para a fresa utilizada (diâmetro $12 \mathrm{~mm}$ ) é de $180 \mathrm{~m} / \mathrm{min}$. Nesta velocidade a rotação do eixo árvore chega a 4775 rpm, próximo do limite da máquina.

Um programa $\mathrm{CNC}$ foi elaborado para a usinagem dos materiais; o qual é mostrado no Apêndice I.

O monitoramento da emissão acústica foi realizado através, de uma unidade de tratamento do sinal, produzida pela Sensis - São Carlos, sendo o modelo utilizado na experimentação o BM12. Um programa para aquisição foi elaborado usando-se o software LabView, o qual mostra e armazena o sinal de Emissão Acústica, cuja tela e o diagrama são mostrados no Apêndice II. Um microcomputador, San Sung ("notebook"), Pentium $100 \mathrm{MHz}$ foi usado para armazenamento e aquisição dos dados. A placa de conversão e aquisição de sinais empregada foi o modelo DAQ CARD 700 com capacidade de aquisição de até 100.000 amostras por segundo da National Instruments. 
O sensor de EA usado é de fabricação da empresa Sensis - São Carlos, com faixa de resposta de até $1 \mathrm{MHz}$. É um sensor piezoelétrico que transforma o sinal de emissão acústica em sinal elétrico. Em princípio a unidade de tratamento de sinal tem a função de receber o sinal bruto captado pelo sensor e amplificar o mesmo; em seguida o sinal passa por um filtro de frequiência (passa altas ou baixas freqüências) que pode ser mudado de acordo com a necessidade. $\mathrm{O}$ circuito principal da unidade de tratamento é responsável pelo cálculo da média RMS do sinal de emissão acústica, já amplificado e filtrado.

O desgaste das ferramentas foi medido através de um microscópio E. Leitz Wetzlar, com sistema de medição na lente ocular do microscópio, com resolução de $0,375 \mu \mathrm{m}(15 \mu \mathrm{inch})$.

Um rugosímetro portátil Taylor-Hobson, modelo Surtronic 3P, foi usado na avaliação do acabamento superficial do material usinado. Os valores de rugosidade medidos são $\mathrm{Ra}(\mu \mathrm{m})$.

Para a remoção dos rasgos fresados durante cada experimento utilizou-se uma retificadora plana TRIPET, com rebolo de óxido de alumínio.

$\mathrm{Na}$ realização das fotografias de microscopia eletrônica, para identificação dos mecanismos e tipos de desgaste, utilizou-se um microscópio eletrônico de varredura Zeiss, modelo DSM 960.

\section{2 - Materiais usinados}

Dentre os aços ferramenta disponíveis no mercado, escolheu-se três dos mais usados na fabricação de moldes e matrizes, são eles: H13, VMO e VC131 (nomes comerciais). Na tabela 3.1 encontra-se os nomes comerciais destes aços, os nomes segundo a AISI (American Iron and Steel Institute) e a composição química média de cada um. 
Tabela 3.1 - Composição química dos aços usinados

\begin{tabular}{|c|c|c|}
\hline Nome comercial & Nome normalizado (AISI) & Composição química \\
\hline H13 & $\mathrm{H} 13$ & $\begin{array}{rll}\text { C 0,4\% } & \text { Cr 5\% } & \text { V 1\% } \\
\text { Mo 0,35\% } & \text { Mn 1,5\% } & \text { Si 1\% }\end{array}$ \\
\hline VMO & $6 \mathrm{~F} 3$ & $\begin{array}{lrr}\text { C } 0,57 \% & \text { Mn 0,7\% } & \text { Cr 1,1\% } \\
\text { Ni 1,65\% } & \text { Mo 0,5\% } & \text { Nb 0,04\% }\end{array}$ \\
\hline VC131 & D6 & $\begin{array}{c}\text { C 2,1\% } \quad \text { Mn 0,3\% } \quad \text { Cr 11,5\% } \\
\text { W } 0,7 \% \quad \text { V 0,2\% }\end{array}$ \\
\hline
\end{tabular}

Abaixo segue o croqui da forma e dimensão de cada material, figura 3.1.

\section{$\mathrm{H} 13$}
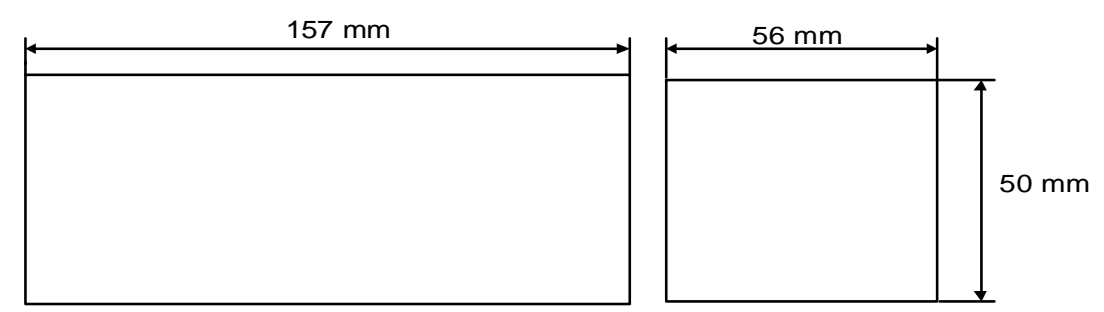

\section{VMO}

$227 \mathrm{~mm}$

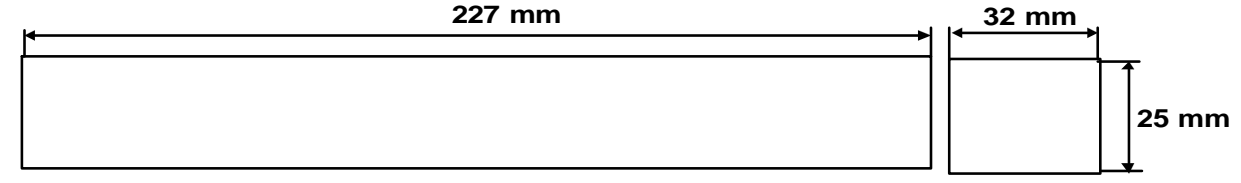

VC131
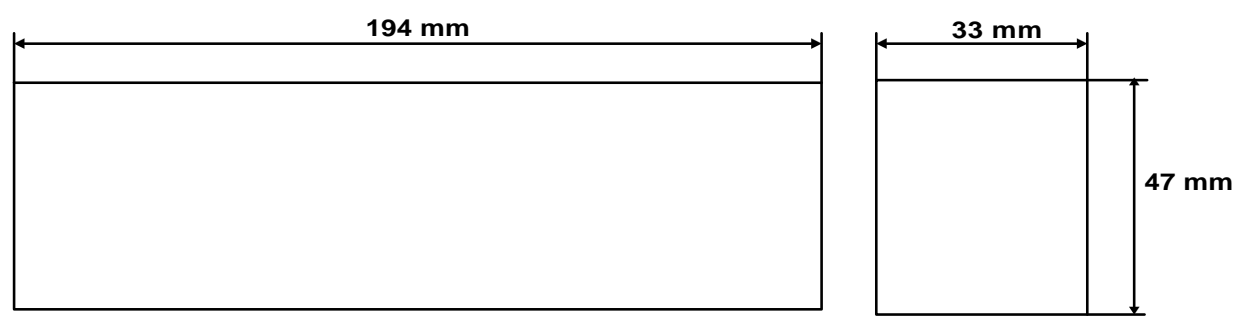

Figura 3.1 - Forma e dimensões dos materiais usinados.

O tratamento térmico foi realizado em uma empresa especializada, JSC Indústria e Comércio de Máquinas e Serviços Ltda. A dureza encontrada em cada um dos blocos está relacionada na tabela 3.2. 
A medição de dureza dos blocos foi realizada, ao longo de toda a experimentação, antes de se iniciar o fresamento de cada superfície para verificar se a dureza mantinha-se em uma faixa aceitável (49 à 51 HRc para o H13, 54 à 57 HRc para o VMO, 57 à 59 para o VC131).

Tabela 3.2 - Valores de dureza para cada bloco de material ao longo da experimentação.

\begin{tabular}{|c|c|c|}
\hline $\mathrm{H} 13$ & VMO & VC131 \\
\hline \multicolumn{3}{|c|}{ Primeira Medição de Dureza (HRc) } \\
\hline $50 / 49 / 49 / 50$ & $54 / 55 / 55 / 54$ & $58 / 58 / 56$ \\
\hline \multicolumn{3}{|c|}{ Segunda Medição de Dureza (HRc) } \\
\hline $51 / 51 / 51 / 51 / 51$ & $57 / 57 / 57 / 58 / 57$ & $59 / 59 / 59 / 59$ \\
\hline \multicolumn{3}{|c|}{ Terceira Medição de Dureza (HRc) } \\
\hline $50 / 50 / 51 / 49 / 49 / 50$ & $57 / 57 / 58 / 57 / 57$ & $59 / 58 / 57 / 59 / 59$ \\
\hline \multicolumn{3}{|c|}{ Quarta Medição de Dureza (HRc) } \\
\hline 49 / 49 / 49 / $50 / 50$ & $56 / 55 / 57 / 54 / 55$ & \\
\hline \multicolumn{3}{|c|}{ Quinta Medição de Dureza (HRc) } \\
\hline $50 / 49 / 52 / 51 / 50$ & & \\
\hline
\end{tabular}

A microestrutura obtida, em cada material, depois do tratamento térmico está na figura 3.2. 


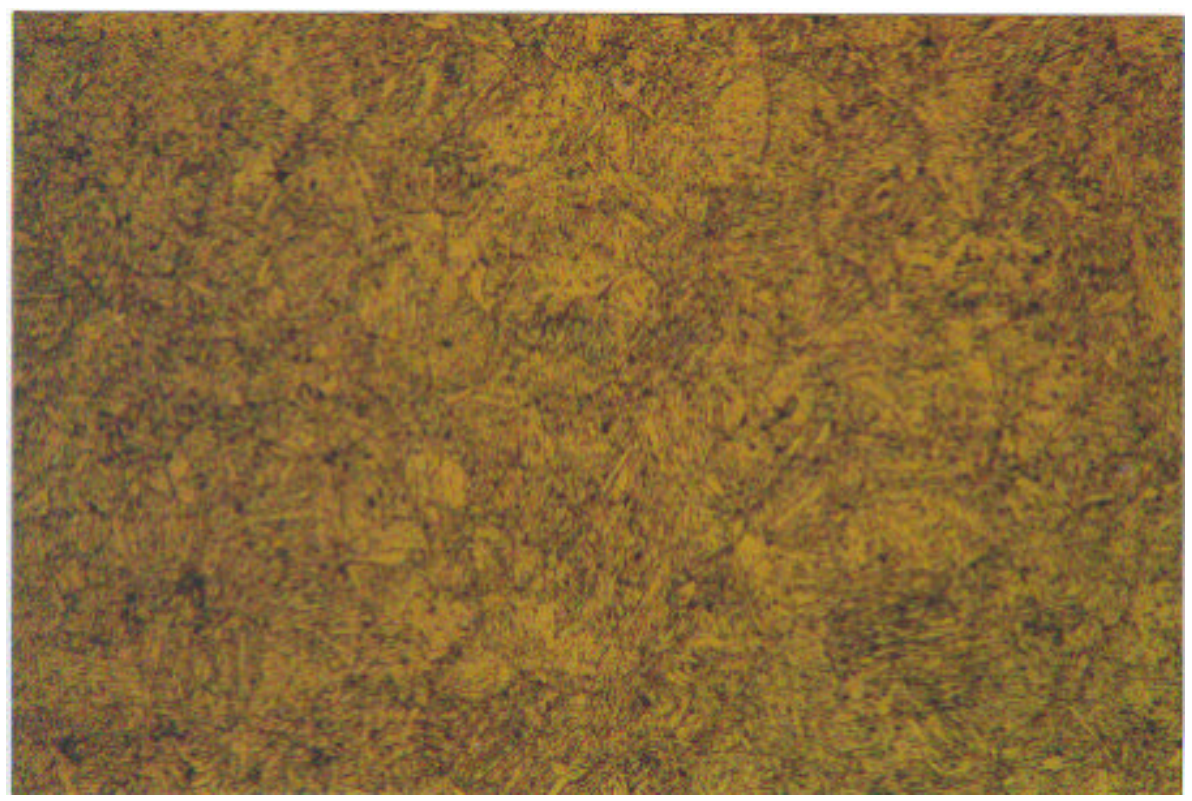

(a) Aço H13 - microestrutura típica - 575 x.

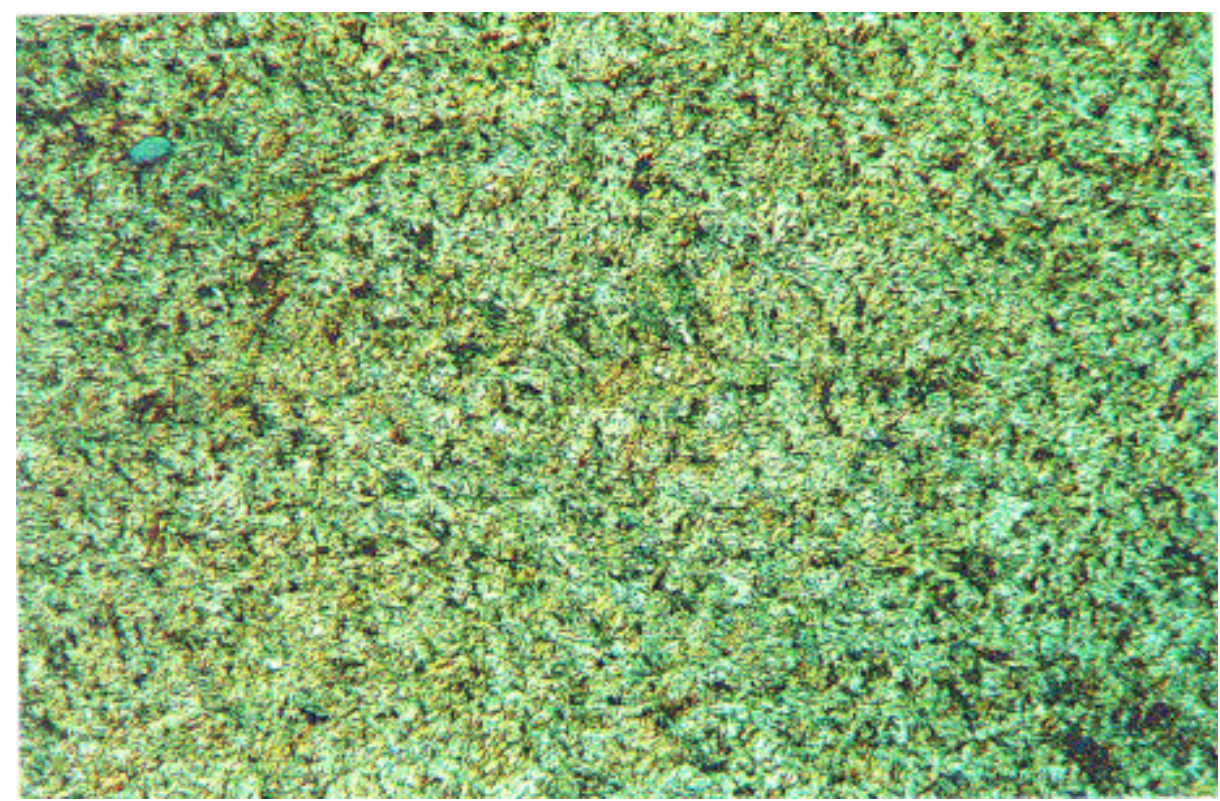

(b) Aço VMO - microestrutura típica - 575x. 


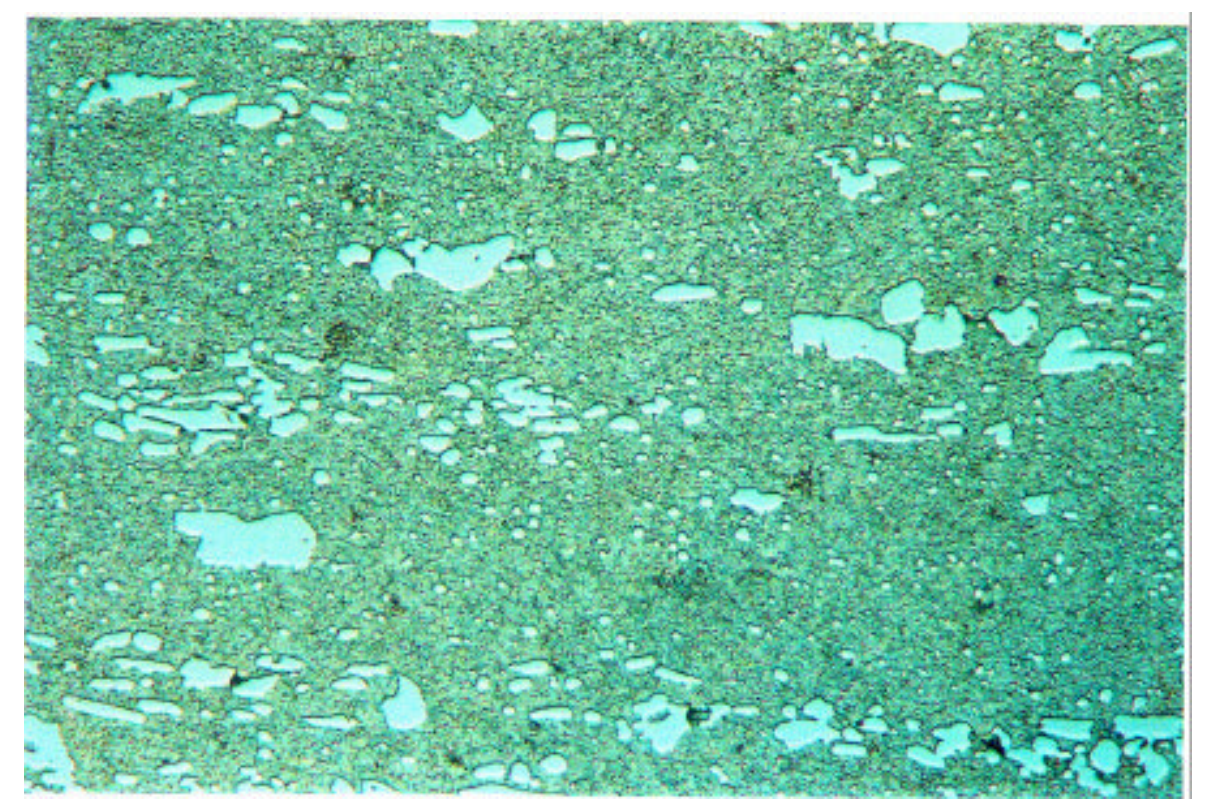

(c) Aço VC131 - microestrutura típica - 575x.

Figura 3.2 - Microestrutura dos materiais usinados.

Pode-se observar a predominância de uma matriz martensítica para os aços H13 e VMO com baixa presença de carbetos de tamanhos variados e formas irregurales. No aço VC131 observa-se a formação de uma matriz de martensita mais carbetos, presentes com muito frequiência, formas irregulares e tamanhos variados.

\section{3 - Ferramentas}

A ferramenta escolhida para a experimentação foi uma fresa de topo de um único inserto indexável, normalmente utilizada na fabricação de moldes e matrizes. Realiza operações de abertura de rasgos e cavidades. A ferramenta, Sandivik, código R216.2-712, diâmetro $12 \mathrm{~mm}$, usa insertos intercambiáveis código R216.2-08 0204 -1A, classe P45. O esquema do inserto segue abaixo na figura 3.3.

A composição básica do Metal Duro usado é o carbeto de tungstênio e um ligante metálico (principalmente o cobalto) recoberto com TiN. Outras partículas duras como carbeto de titânio e carbeto de titânio-nióbio também podem aparecer. 


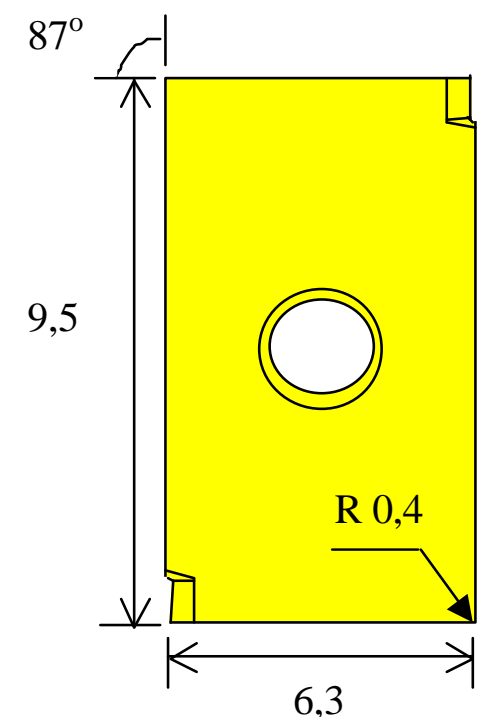

Todas as dimensões estão em mm

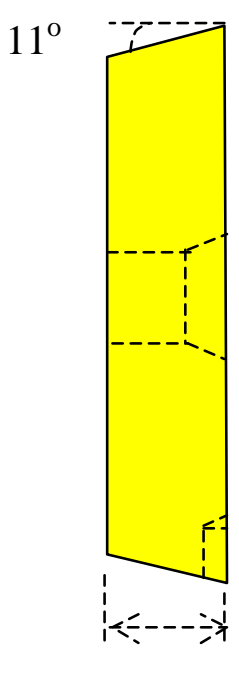

2,38

Figura 3.3 - Esquema do inserto de Metal Duro.

As ferramentas de PCBN consistem de apenas uma aresta de PCBN sobre o mesmo inserto de Metal Duro acima citado, conforme mostra a figura 3.4.

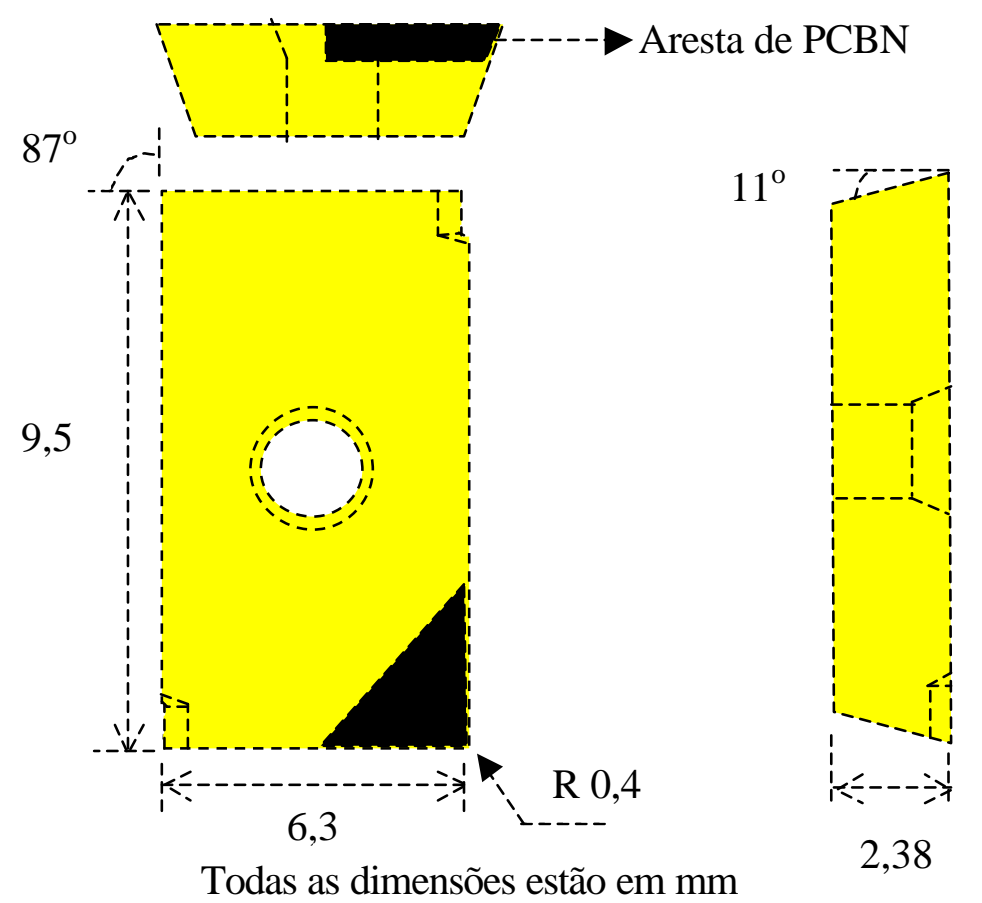

Figura 3.4 - Croqui da ferramenta de PCBN.

O PCBN empregado foi fornecido pela empresa DeBeers do Brasil (São Paulo - Brasil) é tipo DBC50 com 50\% de CBN e matriz cerâmica. Parte dos 
insertos, com aresta de CBN, foram fornecidos pela empresa DIFER do Brasil (São Paulo - Brasil) e parte pela empresa NIXON Industrial Diamonds (Coventry - Inglaterra).

A figura 3.5 mostra a microestrututa do PCBN empregado, obtida por microscópio eletrônico de varredura (SEM).

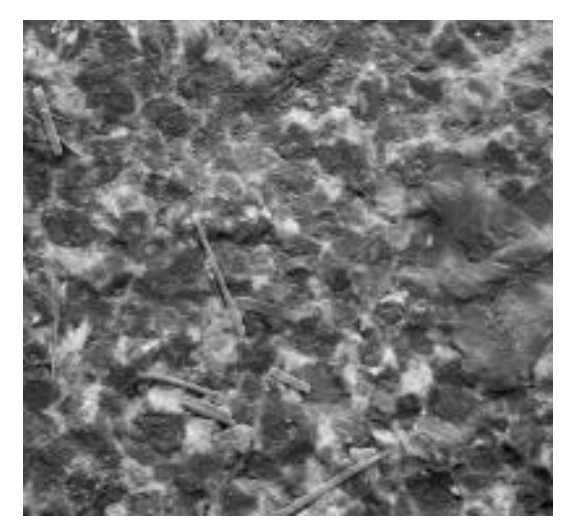

Figura 3.5 - Microestrutura típica do PCBN usado.

$\mathrm{Na}$ figura 3.5, os pontos mais escuros são os grãos de $\mathrm{CBN}$ na matriz cerâmica.

\section{4 - Planejamento e procedimento experimental}

\subsection{1 - Montagem do banco de ensaios}

Foi montado um banco de ensaio para a realização dos experimentos, composto de um centro de usinagem, um sensor de emissão acústica, uma unidade de tratamento do sinal de emissão acústica e um microcomputador para aquisição do sinal de emissão acústica, como mostra a figura 3.6. 


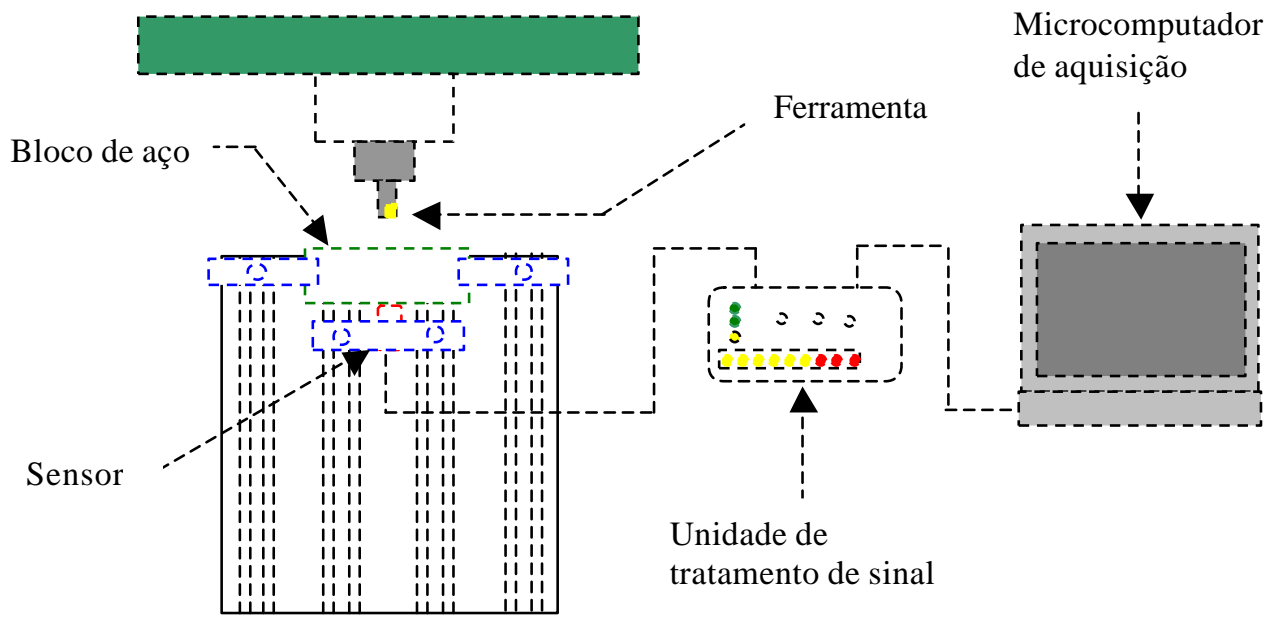

VISTA SUPERIOR DO BANCO DE ENSAIOS

Figura 3.6 - Banco de ensaio utilizado na experimentação.

\subsection{2 - Planejamento dos experimentos}

Foram feitos ensaios preliminares para definição do avanço. Nestes avanços da ordem de 0,02 a 0,1 foram testados com velocidades entre 20 e 100 $\mathrm{m} / \mathrm{min}$. Observou-se a durabilidade dos insertos de modo que fosse possível medir-se a vida em pelo menos uma passada. A velocidade de corte foi definida em vários níveis, desde a máxima velocidade permitida pela máquina até valores possíveis de se usar com ferramentas de MD. A profundidade de usinagem foi adotada dentro de uma faixa de valores recomendada pela literatura (Heath, 1989), embora em operações de acabamento pode-se empregar valores menores que o adotado. A tabela 3.3 mostra os parâmetros de corte adotados.

Tabela 3.3 - Parâmetros de corte adotados.

\begin{tabular}{|c|c|c|}
\hline $\begin{array}{c}\text { Velocidade de corte } \\
(\mathrm{m} / \mathrm{min})\end{array}$ & $\begin{array}{c}\text { Avanço } \\
(\mathrm{mm} / \mathrm{dente})\end{array}$ & $\begin{array}{c}\text { Profundidade de usinagem } \\
(\mathrm{mm})\end{array}$ \\
\hline 20 & 0,02 & \multirow{2}{*}{1} \\
\hline 60 & 0,05 & \\
\hline 100 & 0,1 & \\
\hline 180 & & \\
\hline
\end{tabular}


Alguns trabalhos que tratam de usinagem com ferramentas de PCBN foram realizados sem o uso de fluido de corte (Lin, et al., 1995) (Ohtani, et al., 1988) (König, et al., 1993) (Davies, et al., 1996). Em um experimento inicial com uma ferramenta de PCBN utilizando o fluido de corte, observou-se um lascamento muito forte na ferramenta (conforme figura 4.19, no Capítulo 4 - RESULTADOS E DISCUSSÕES). Portanto, nos experimentos seguintes não se utilizou fluido de corte.

Com os parâmetros de corte definidos pôde-se montar a matriz de experimentos, conforme mostrado na tabela 3.4.

Tabela 3.4 - Matriz de Experimentos.

\begin{tabular}{|c|c|c|c|c|}
\hline $\begin{array}{l}\text { Material } \\
\text { usinado }\end{array}$ & $\begin{array}{l}\text { Material da } \\
\text { ferramenta }\end{array}$ & $\begin{array}{l}\text { Velocidade de } \\
\text { corte }(\mathrm{m} / \mathrm{min})\end{array}$ & $\begin{array}{c}\text { Avanço } \\
\text { (mm/dente) }\end{array}$ & $\begin{array}{c}\text { Profundidade } \\
\text { de usinagem } \\
\text { (mm) }\end{array}$ \\
\hline H13 & $\mathrm{MD}$ & 20 & 0,05 & 1 \\
\hline H13 & $\mathrm{MD}$ & 60 & 0,05 & 1 \\
\hline H13 & $\mathrm{MD}$ & 60 & 0,1 & 1 \\
\hline H13 & $\mathrm{MD}$ & 100 & 0,05 & 1 \\
\hline H13 & MD & 100 & 0,1 & 1 \\
\hline H13 & MD & 60 & 0,02 & 1 \\
\hline VMO & $\mathrm{MD}$ & 60 & 0,02 & 1 \\
\hline VC131 & MD & 60 & 0,02 & 1 \\
\hline H13 & PCBN & 60 & 0,02 & 1 \\
\hline VMO & PCBN & 60 & 0,02 & 1 \\
\hline VC131 & PCBN & 60 & 0,02 & 1 \\
\hline H13 & MD & 100 & 0,02 & 1 \\
\hline H13 & PCBN & 100 & 0,02 & 1 \\
\hline H13 & MD & 180 & 0,02 & 1 \\
\hline VMO & MD & 180 & 0,02 & 1 \\
\hline VC131 & MD & 180 & 0,02 & 1 \\
\hline
\end{tabular}




\subsection{3 - Montagem do sensor de emissão acústica e medição do sinal}

O sensor de EA foi fixado na mesa do centro de usinagem, com o auxilio de uma chapa e dois parafusos, o mais próximo possível do material sendo usinado, conforme mostra a figura 3.7.

O ganho do sensor de emissão acústica foi ajustado fazendo-se a usinagem de um material de dureza semelhante a dureza dos materiais ensaiados. Usando-se uma condição de corte severa, na qual espera-se que o nível de EA seja máximo, ajustou-se o ganho da unidade de tratamento de sinal para próximo do máximo. Da mesma forma, usando-se uma condição suave, constatou-se que havia sinal suficientemente alto para a medição. $O$ ganho foi ajustado na unidade de tratamento do sinal, e uma vez ajustado não foi alterado durante os experimentos.

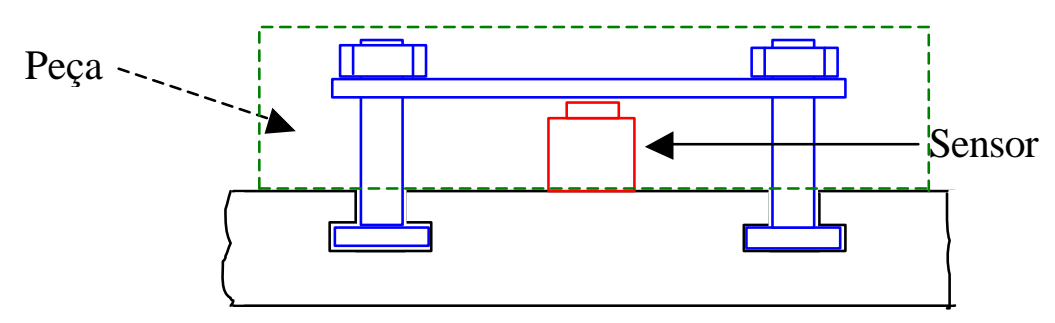

Figura 3.7 - Fixação do sensor de emissão acústica.

Nesta etapa também foi inserido na unidade de tratamento de sinal um filtro de frequiência para atenuação do ruído presente no sinal de emissão acústica. O filtro utilizado é de $2.500 \mathrm{~Hz}$ passa alta, isto é, este filtro só permite a passagem de freqüências acima de $2.500 \mathrm{~Hz}$. O valor de integração do RMS foi ajustado, através de capacitores para uma valor de aproximadamente 1 milisegundo.

A unidade de tratamento de sinal é conectada a um microcomputador responsável pela aquisição do sinal e o programa ajustado para a aquisição de 20 pontos por segundo, uma vez que somente o nível médio de sinal foi requerido. $\mathrm{O}$ sistema de aquisição de sinal de emissão acústica é mostrado na figura 3.8. 


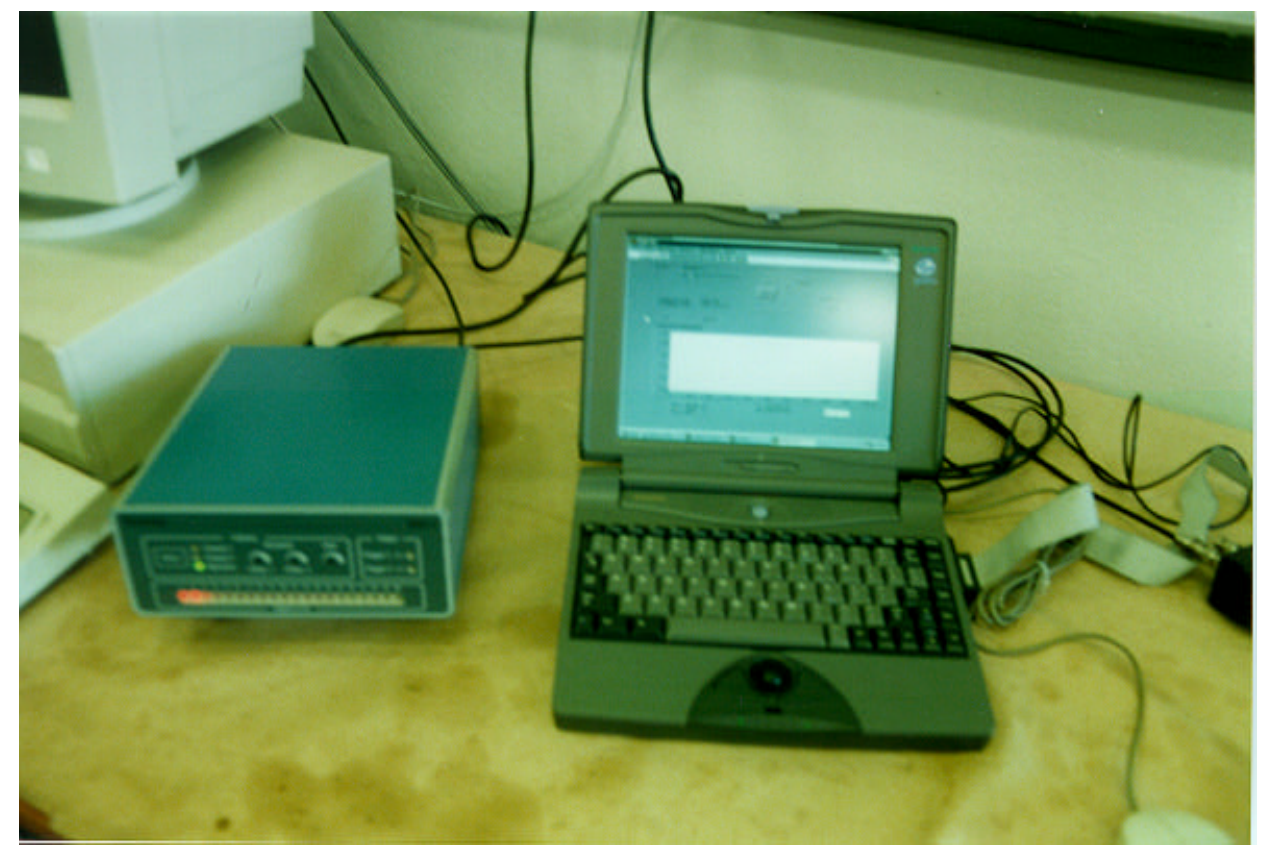

Figura 3.8 - Sistema de aquisição do sinal de emissão acústica.

O procedimento de aquisição do sinal consiste em inicializar o software de aquisição junto como o programa de usinagem. Assim que a usinagem foi encerrada a aquisição também foi interrompida. Os dados foram armazenados em arquivos do tipo "Excel”, para posterior análise.

\subsection{4 - Usinagem dos blocos}

Foram usinadas apenas duas faces opostas de cada bloco (vide figura 3.1), procurando-se aproveitar ao máximo o material. Os materiais usinados foram presos sobre a mesa do centro de usinagem através de grampos, como mostra a figura 3.9.

Para garantir o paralelismo entre a face dos blocos e o eixo " $\mathrm{X}$ " do centro de usinagem fez-se uso de um relógio apalpador com fundo de escala de 0,01 $\mathrm{mm}$. Toda as vezes que havia nova fixação dos blocos, o paralelismo foi conferido. Prendeu-se o relógio apalpador ao eixo árvore (através de uma pinça), deslocando-o ao longo do comprimento do bloco através do eixo " $\mathrm{X}$ " da máquina, o qual também foi usado para a usinagem. $\mathrm{O}$ procedimento foi repetido até que $\mathrm{o}$ paralelismo fosse alcançado. Isto foi feito para manter uma profundidade de usinagem constante $(1 \mathrm{~mm})$ ao longo do comprimento do bloco. 


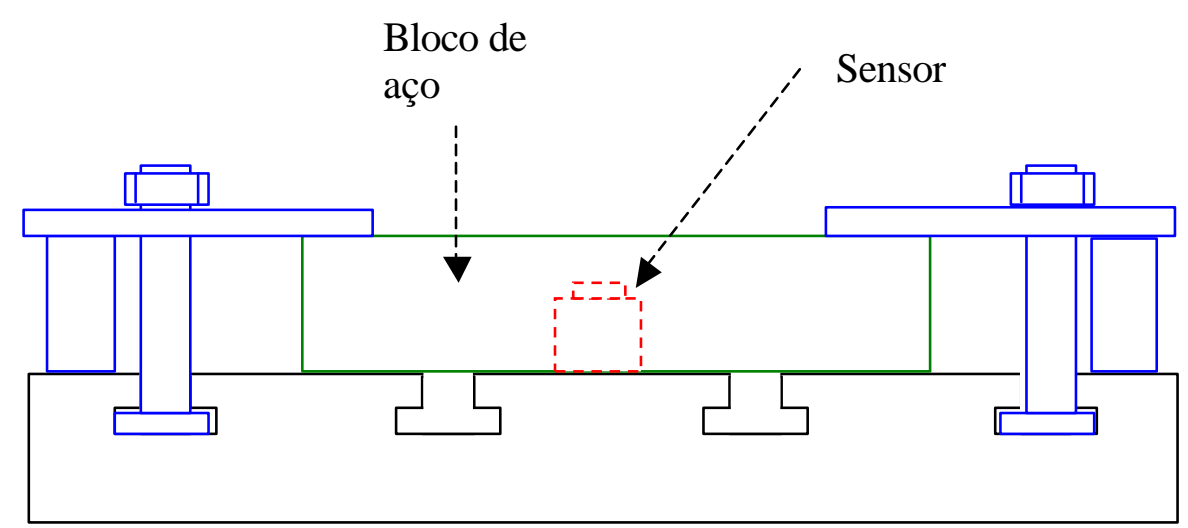

Figura 3.9 - Fixação do bloco a ser usinado na mesa do centro de usinagem.

O experimento consistiu em usinar um rasgo, de cada vez, ao longo do comprimento dos blocos, em condições de usinagem pré determinadas pela matriz de experimentos.

Ao final de cada rasgo o inserto foi retirado da fresa para medição de desgaste, que será abordada na próxima seção.

Quando as duas faces do bloco já tinham sido completamente fresadas, o bloco foi retirado do centro de usinagem para a medição de rugosidade, que será descrita mais a frente neste capítulo. Em seguida foi levado até a retificadora plana para remoção dos rasgos usinados e submetido a nova medida a dureza, conforme mostrado na tabela 3.2.

Este procedimento foi repetido até o volume usinado atingir cerca de $40.000 \mathrm{~mm}^{3}$ ou o desgaste de flanco na ferramenta atingir valores acima de 0,5 $\mathrm{mm}$, quando se encerrou o experimento.

\subsection{5 - Medição do desgaste de flanco}

Após cada passe (ou rasgo usinado) o inserto foi retirado da fresa para medição do desgaste de flanco em um microscópio. Foi medido o desgaste máximo de flanco $\left(\mathrm{V}_{\mathrm{B}} \mathrm{em} \mathrm{mm}\right)$. 
O inserto foi preso em um suporte, conforme a figura 3.10, para permitir que uma melhor visualização da superfície desgastada e para medição num plano contendo a velocidade de corte e o eixo de giro da fresa.

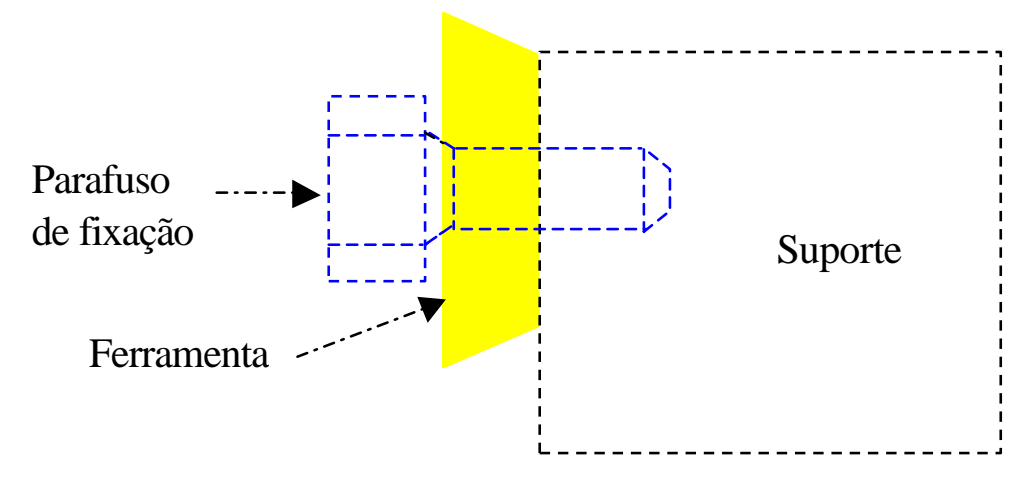

Figura 3.10 - Fixação da ferramenta para medição do desgaste de flanco.

O ciclo se repete até o fim do experimento.

\subsection{6 - Medição da Rugosidade}

Fêz-se uso de um rugosímetro portátil, medindo-se Ra $(\mu \mathrm{m})$ com um "cut off" ajustado para $0,8 \mathrm{~mm}$.

A medição foi realizada em 10 pontos aleatórios ao longo do comprimento de cada rasgo usinado. A média destes valores foi colocada como um ponto nos gráficos de resultados

\subsection{7 - Preparação das amostras para análise de microestrura dos aços usinados}

Para a análise de microestrutura foram retiradas de cada bloco uma fatia de material, abrangendo o vértice do rasgo usinado. As amostras seguiram os seguintes passos: embutimento em resina; polimento - que começa com uma sequiência de lixas (180 à 600) passa pelo óxido de cromo (CrO)e termina na $\mathrm{Al}_{2} \mathrm{O}_{3}$ em uma politriz. Depois que as amostras foram polidas foi feito o ataque químico - Nital 5\% (5\% de ácido nítrico e os outros 95\% de álcool etílico). As amostras depois de preparadas foram analisados em um microscópio óptico onde 
foram feitas fotografias da matriz de cada aço e da camada abaixo da região usinada, no vértice dos rasgos.

\subsection{8 - Preparação das amostras para análise em microscópio eletrônico de varredura (SEM)}

As ferramentas foram coladas em suportes de alumínio, os quais foram fixados na mesa do microscópio, figura 3.11. Para estabelecer um contato elétrico entre a ferramenta e o suporte fez-se uso de uma tinta a base de prata que foi aplicada em pequenas regiões. A última etapa de preparação foi a deposição de um filme de ouro sobre o conjunto ferramenta/suporte, necessário para aumentar o condutividade elétrica, principalmente do CBN

As fotografias foram feitas das regiões desgastadas na tentativa de encontrar evidências que pudessem identificar os mecanismos de desgaste atuantes. As ampliações das fotografias foram ajustadas de maneira que permitisse uma visão geral da aresta de corte desgastada e também mostrasse detalhes do desgaste.

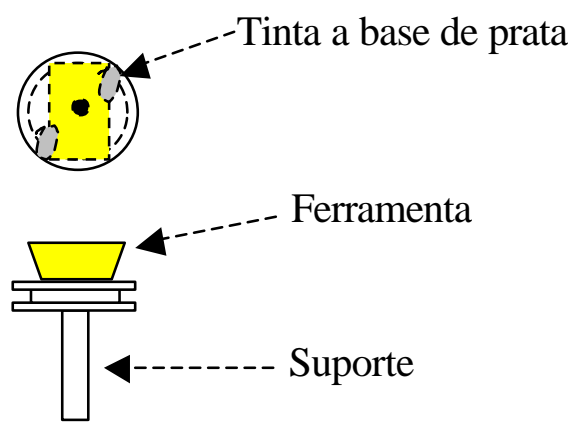

Figura 3.11 - Ferramenta fixada no suporte do microscópio eletrônico de varredura. 


\section{0 - RESULTADOS E DISCUSSÕES}

Este capítulo está dividido em quatro sub tópicos para facilitar a análise dos resultados.

\section{1 - Resultados de desgaste e rugosidade}

Apresenta-se uma comparação entre o desempenho das ferramentas de corte (com relação ao desgaste de flanco) variando-se o material da ferramenta, o material usinado e os parâmetros de corte. $\mathrm{O}$ ensaio foi interrompido quando o desgaste de flanco alcançou o valor próximo ou superior a $0,5 \mathrm{~mm}$, ou então, quando o volume de material removido chegou em torno de $40.000 \mathrm{~mm}^{3}$. O acabamento superficial do material usinado é avaliado através da rugosidade superficial (Ra). As linhas traçadas nos gráficos são curvas de tendência com o intuito de ajudar a compreensão dos dados, mas sem a preocupação de ajuste matemático em relação aos pontos.

\subsection{1 - Influência do material usinado no desgaste das ferramentas}

$\mathrm{Na}$ primeira série de ensaios, os parâmetros de corte foram mantidos constantes (velocidade de corte - $60 \mathrm{~m} / \mathrm{min}$; avanço - 0,02 $\mathrm{mm} / \mathrm{dente}$; profundidade de usinagem - $1 \mathrm{~mm}$ ), usinando-se os três materiais H13, VMO e VC131, com as ferramentas de MD e PCBN.

A figura 4.1(a) mostra a evolução do desgaste de flanco quando usinando o aço H13. Nota-se que a ferramenta de MD apresentou um desgaste muito mais acelerado, com um rápido crescimento a partir de cerca de $2.000 \mathrm{~mm}^{3}$. A ferramenta de PCBN partiu com um desgaste inicial mais elevado, porém manteve-se estável, ao longo da usinagem, em torno de $0,4 \mathrm{~mm}$. 
A rugosidade, figura 4.1(b), obtida na usinagem com a ferramenta de MD mostra uma tendência de crescimento, enquanto que a rugosidade obtida na usinagem com PCBN começou crescendo, depois estabilizando-se em torno de $0,3 \mu \mathrm{m}$.

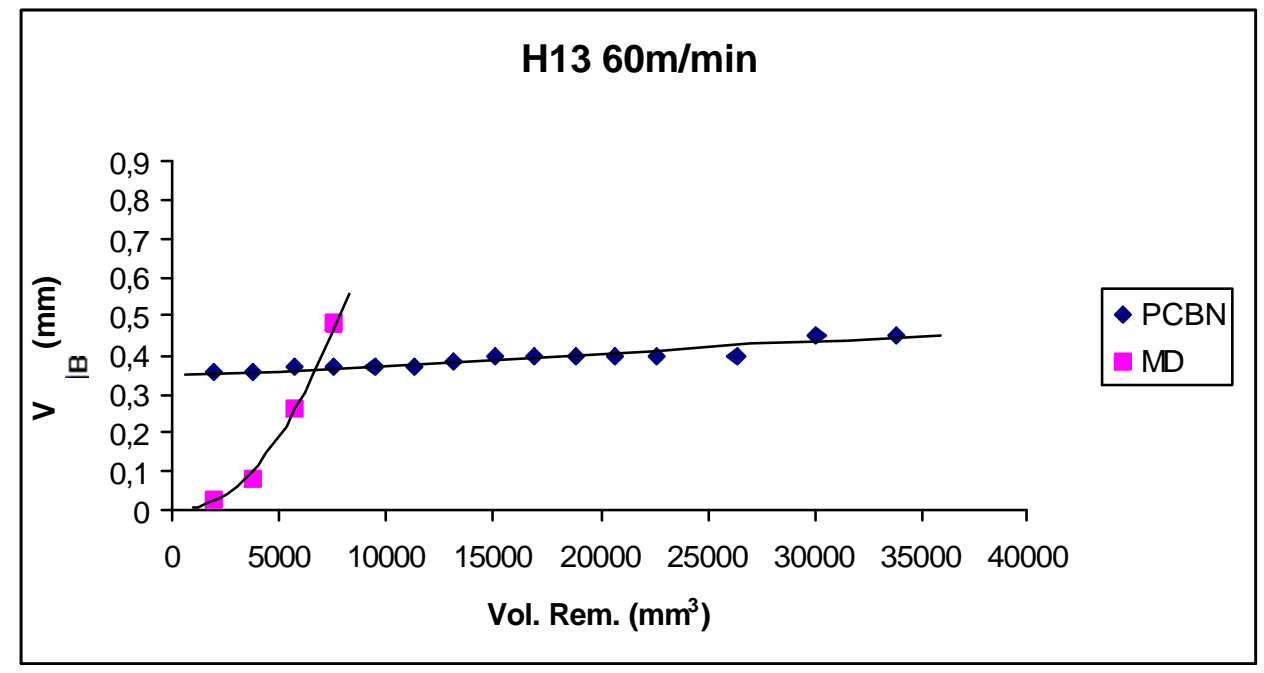

(a) Tendência de desgaste de flanco

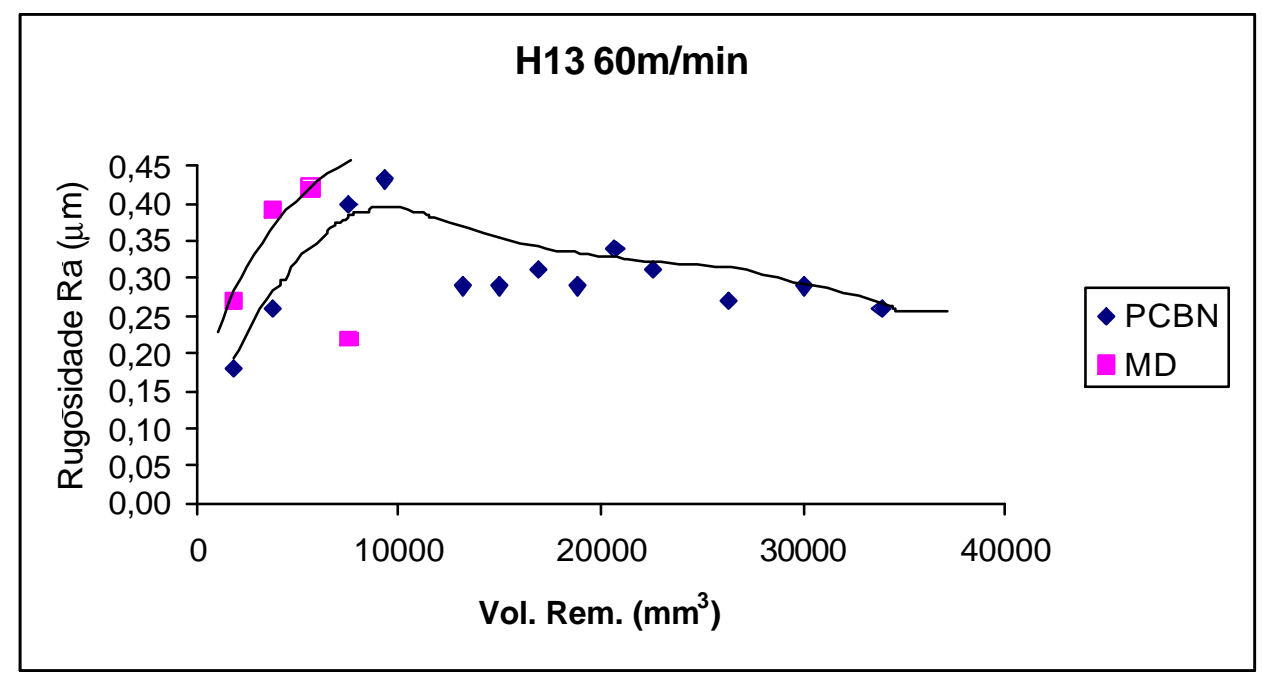

(b) Rugosidade Ra

Figura 4.1 - Resultados de experimento de desgaste de flanco e de rugosidade superficial na usinagem do aço $\mathrm{H} 13$.

Na usinagem do aço VMO o desgaste observado na ferramenta de PCBN é muito baixo, figura 4.2(a), comparado aos demais. Nesta figura encontra-se a medida de duas componentes do desgaste: a primeira é o desgaste de flanco médio e a segunda é o desgaste de flanco máximo. Isto foi devido à identificação de uma 
única região com desgaste elevado e o restante da aresta de corte apresenta um desgaste mínimo. Nas duas componentes do desgaste de flanco a evolução do desgaste é estável, menos de 0,1 mm no desgaste médio de flanco e em torno de 0,28mm no desgaste máximo de flanco.

A ferramenta de MD apresenta desgaste elevado logo no início, chegando em 0,6 mm de desgaste já com o volume removido da ordem de $3.200 \mathrm{~mm}^{3}$, figura 4.2(a).

A rugosidade deixada pela ferramenta de MD, apesar de um ensaio curto, apresenta um tendência de queda. Já com a ferramenta de PCBN os valores de rugosidade oscilam bastante, em torno de $0,25 \mu \mathrm{m}$, figura 4.2(b).

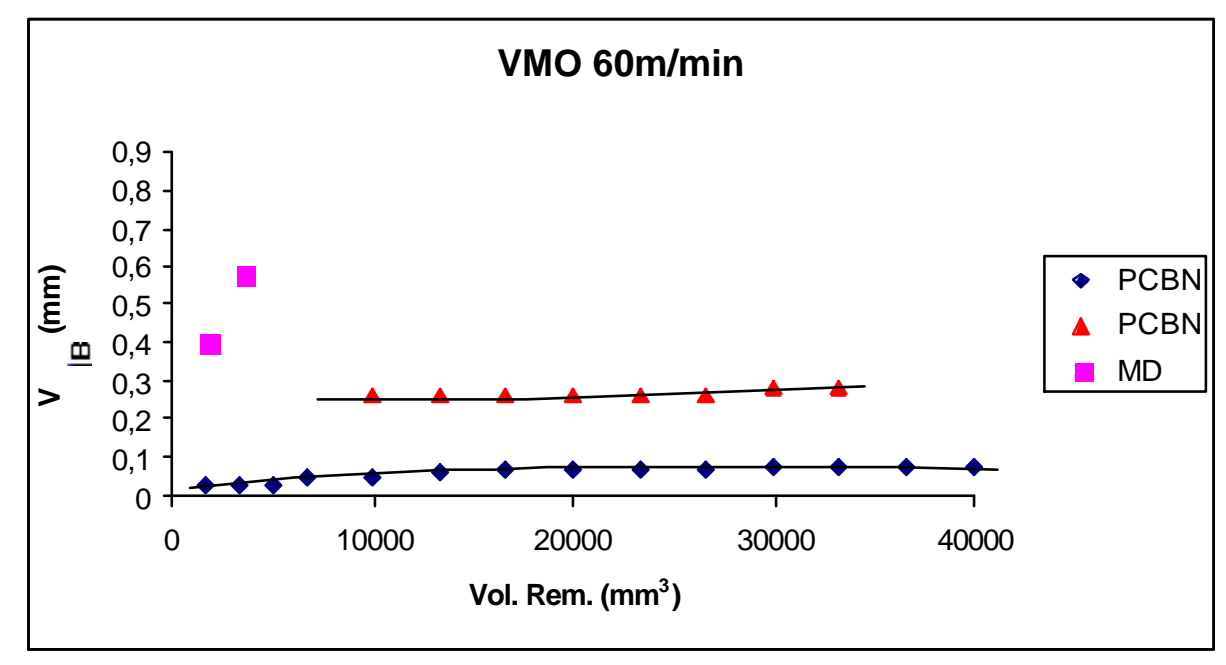

(a) Tendência de desgaste de flanco

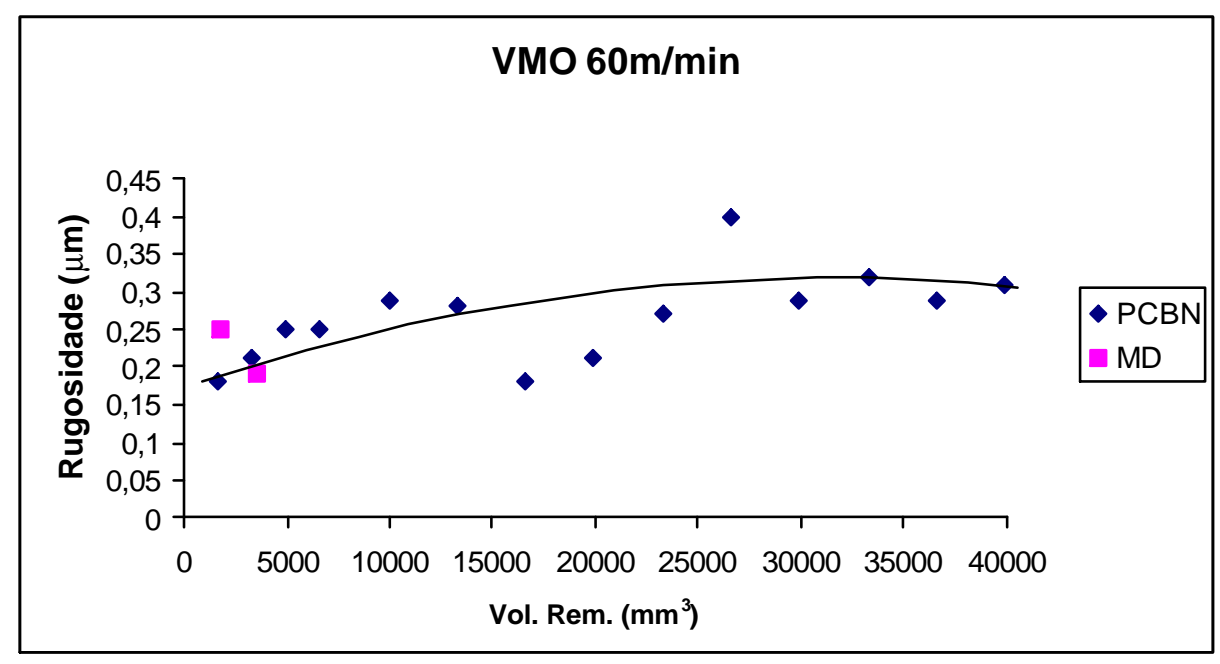

(b) Rugosidade Ra

Figura 4.2 - Resultados de experimento de desgaste de flanco e de rugosidade superficial na usinagem do aço VMO. 
Na usinagem do aço VC131 observou-se um desgaste mais severo tanto para a ferramenta de MD quanto para a ferramenta de PCBN. A primeira, em um único passe de ensaio, cerca de $2.400 \mathrm{~mm}^{3}$, mostra um desgaste de flanco superior a $0,7 \mathrm{~mm}$. A segunda, cujo desgaste evoluiu em patamares como mostra a figura 4.3(a), chega a mais de $0,5 \mathrm{~mm}$ de desgaste de flanco. Comparando-se com os materiais anteriores, o volume total removido é de aproximadamente a metade daquele usinado com os aços H13 e VMO.

A rugosidade obtida na usinagem com a ferramenta de PCBN tem uma tendência de queda ao longo da usinagem com um valor médio em torno de 0,25 $\mu \mathrm{m}$, figura 4.3(b). No ensaio com ferramenta de MD o único valor de rugosidade é $0,2 \mu \mathrm{m}$.

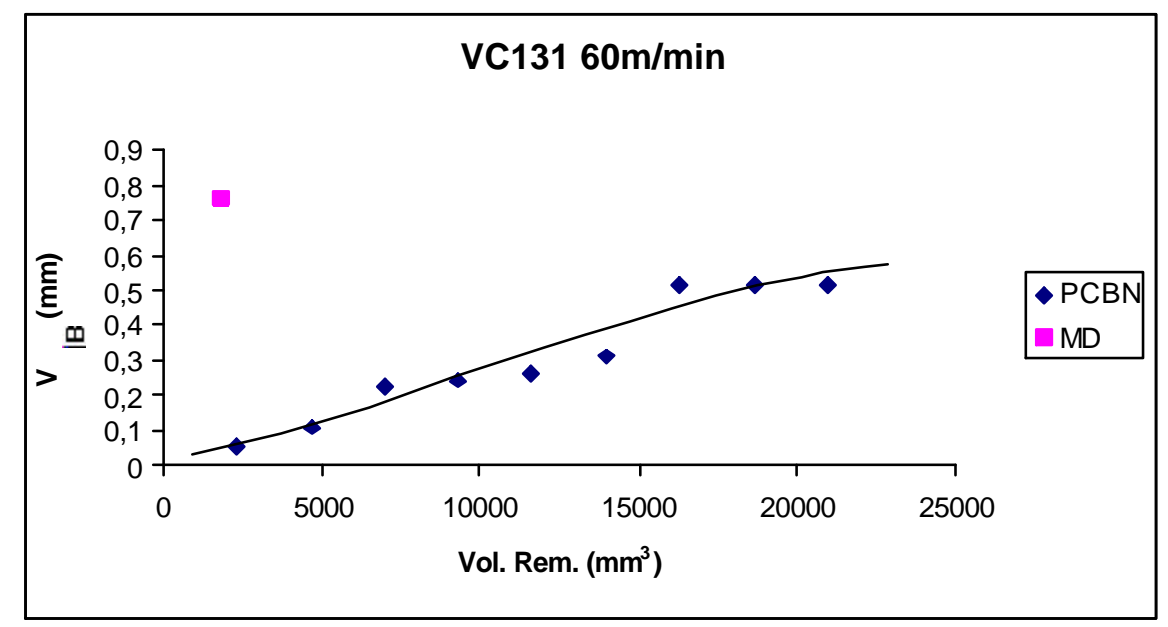

(a) Tendência de desgaste de flanco

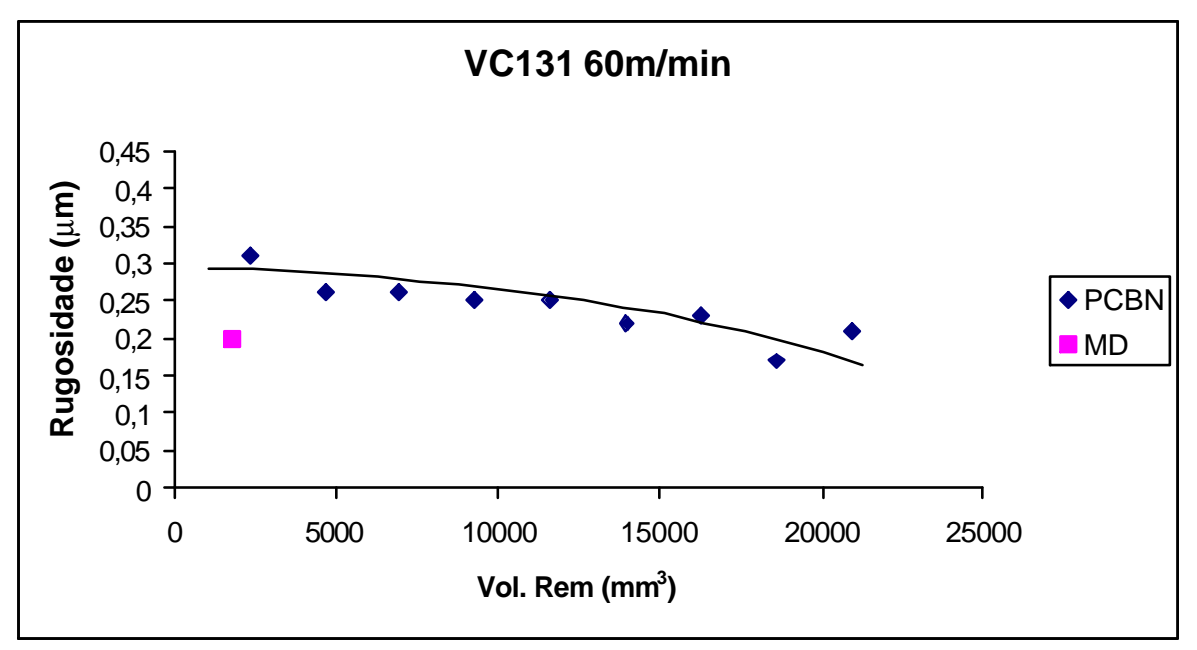

(b) Rugosidade Ra

Figura 4.3 - Resultados de experimento de desgaste de flanco e de rugosidade superficial na usinagem do aço VC131. 


\subsection{2 - Influência da velocidade de corte no desgaste das ferramentas}

Uma segunda série de ensaios é mostrada, na qual procura-se explorar valores extremos das variáveis. Varía-se, nesta série, a velocidade de corte $(60$, 100 e $180 \mathrm{~m} / \mathrm{min}$ ), usando-se os dois materiais de ferramenta (PCBN e MD) e os três materiais usinados (H13, VMO e VC131). A profundidade de usinagem e o avanço são mantidos constantes, respectivamente $1,0 \mathrm{~mm}$ e $0,02 \mathrm{~mm} / \mathrm{dente}$. Devido ao elevado número de experimentos, nem todas as combinações entre os diversos parâmetros (velocidade de corte, material de ferramenta e material usinado) foram realizadas.

Na usinagem do aço H13 o desgaste de flanco mostra-se dependente da velocidade de corte, figura 4.4(a). Pode-se observar, para PCBN, que o maior desgaste está em $100 \mathrm{~m} / \mathrm{min}$. Para a ferramenta de MD, o desgaste observado em $180 \mathrm{~m} / \mathrm{min}$ foi maior do que o valor para $60 \mathrm{~m} / \mathrm{min}$, porém menor do que aquele observado em $100 \mathrm{~m} / \mathrm{min}$.

A rugosidade das condições PCBN/60 m/min, PCBN/100 m/min e MD/60 $\mathrm{m} / \mathrm{min}$ apresentam-se maiores no início de cada ensaio seguido de uma tendência de queda e estabilização, figura 4.4(b). Na condição MD/100 m/min a rugosidade foi muito elevada (mais de $0,6 \mu \mathrm{m}$ ) e na combinação $\mathrm{MD} / 180 \mathrm{~m} / \mathrm{min}$ a rugosidade foi de aproximadamente $0,25 \mu \mathrm{m}$.

A rugosidade não demostrou uma relação clara com a velocidade de corte, mas sim com relação ao desgaste.

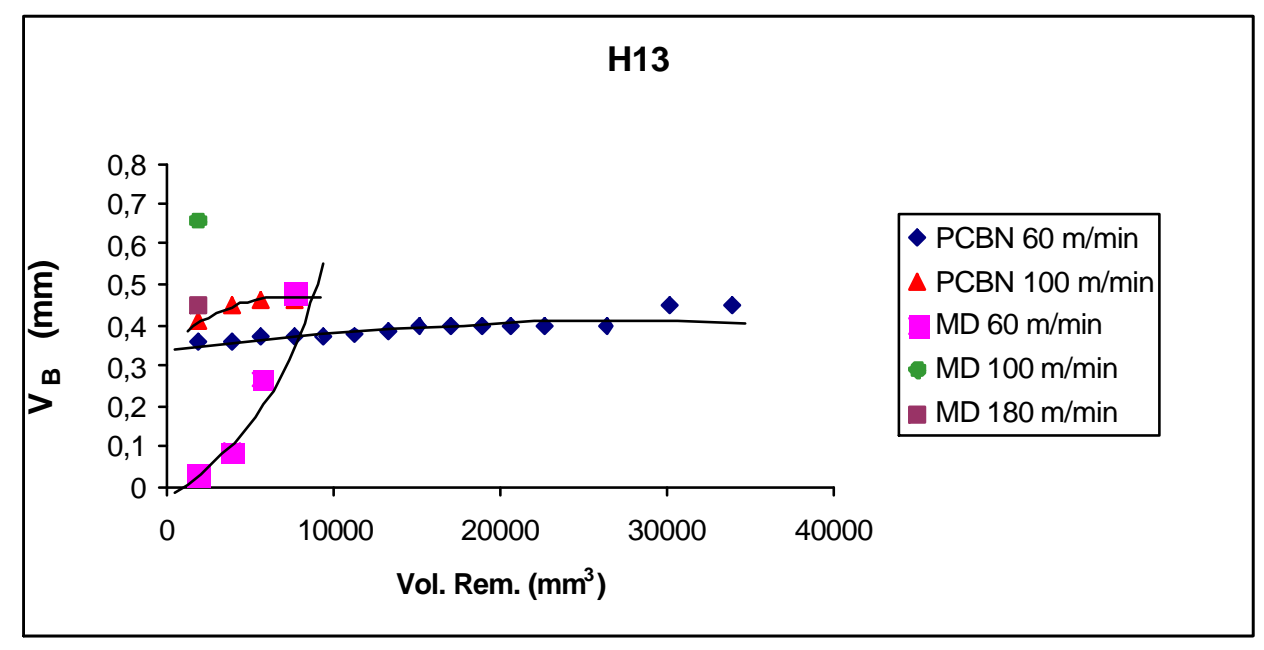

(a) Tendência de desgaste de flanco. 


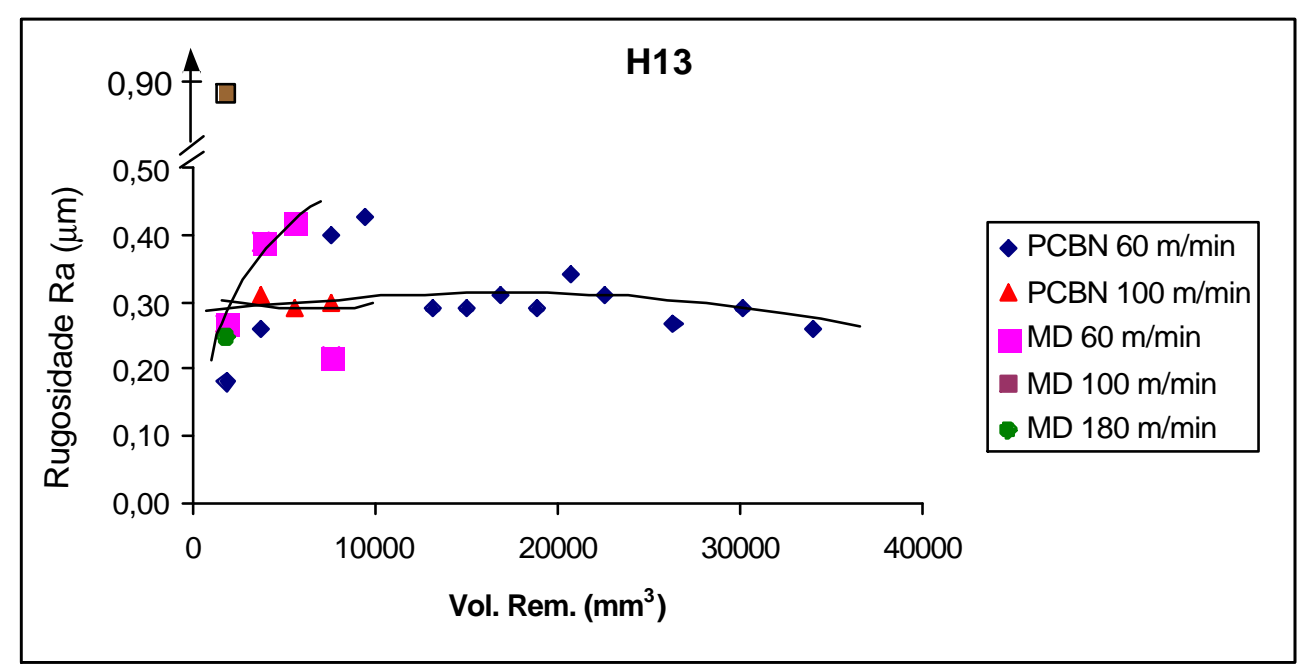

(b) Rugosidade Ra

Figura 4.4 - Gráficos de desgaste de flanco e de rugosidade superficial na usinagem do aço $\mathrm{H} 13$ em várias velocidades de corte.

A figura 4.5(a) referente ao aço VMO mostra que o desgaste de flanco é menor para a ferramenta de PCBN. No experimento realizado com a condição PCBN/60 m/min o desgaste de flanco médio ficou abaixo de $0,1 \mathrm{~mm}$ e o desgaste de flanco máximo ao redor de 0,3 mm. Nas condições MD/60 m/min e MD180/min o desgaste inicial é de 0,4 mm e aumenta de acordo com a velocidade de corte.

A rugosidade para a condição PCBN/60 $\mathrm{m} / \mathrm{min}$ oscila bastante com tendência de crescimento, figura 4.5(b). Nas duas condições com MD o número de pontos é insuficiente para mostrar uma tendência, a rugosidade fica entre $0,2 \mathrm{e}$ $0,25 \mu \mathrm{m}$. 


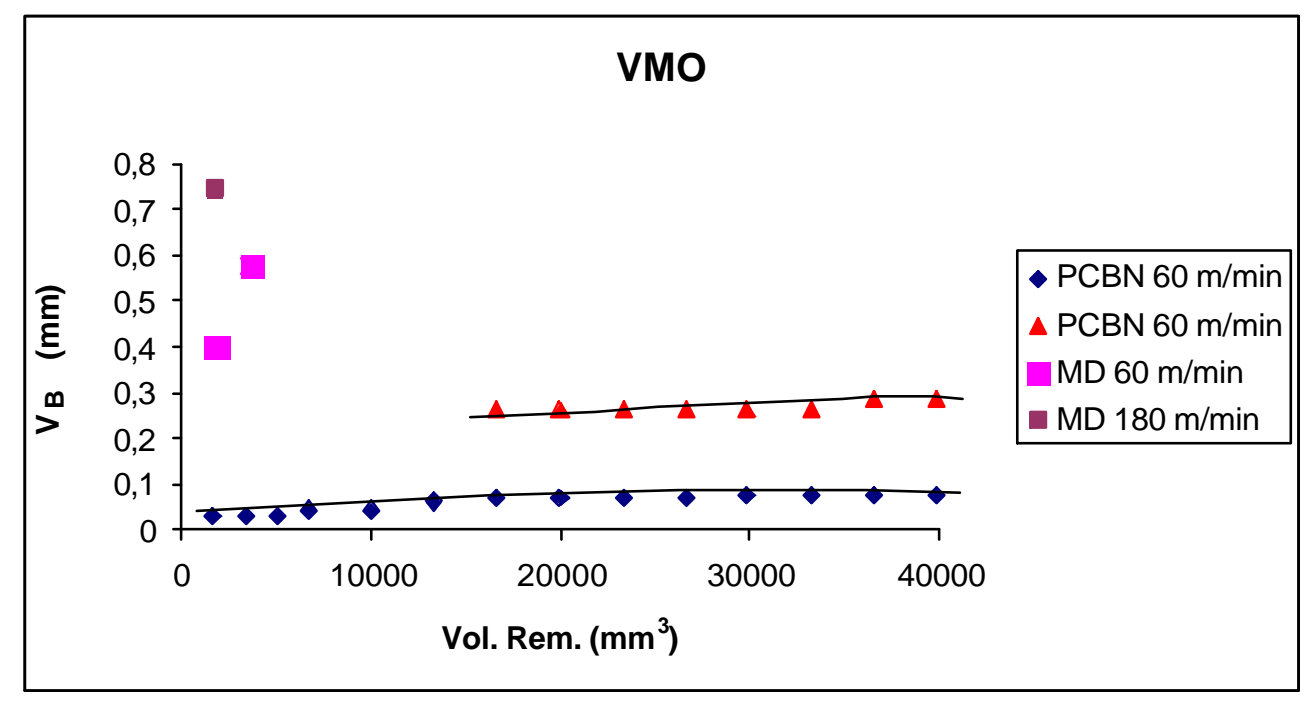

(a) Tendência de desgaste de flanco

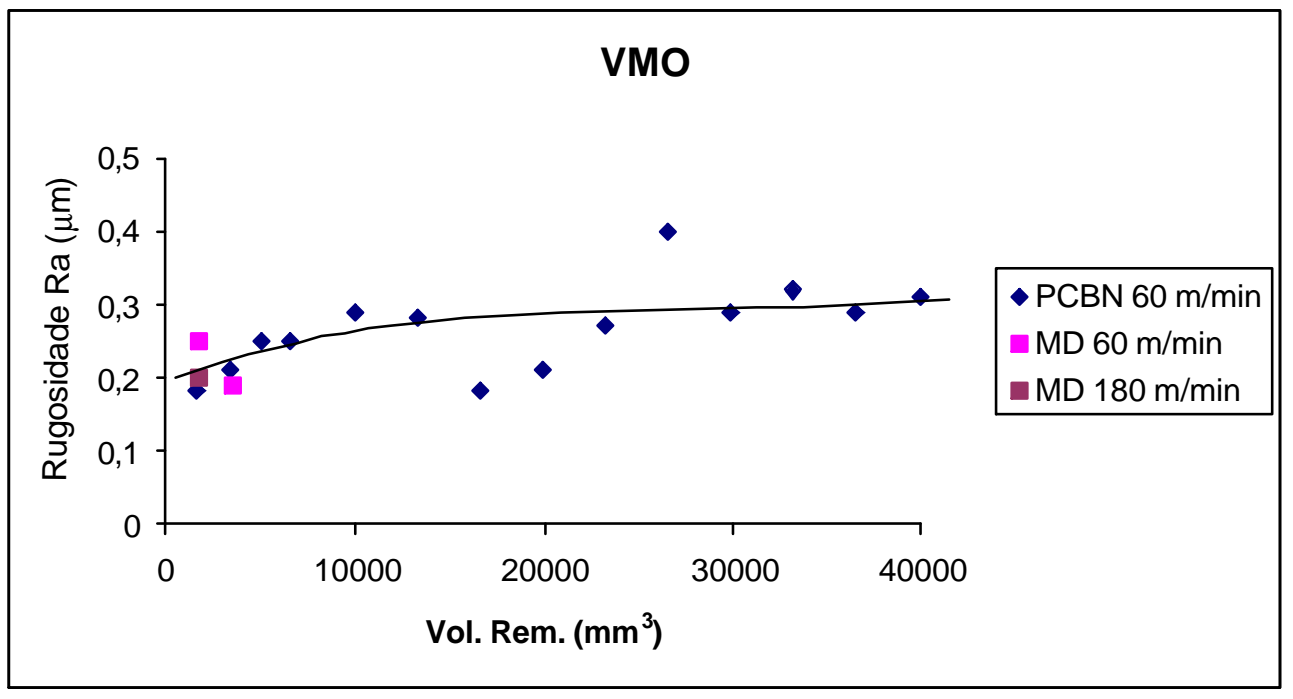

(b) Rugosidade Ra

Figura 4.5 - Gráficos de desgaste de flanco e de rugosidade superficial na usinagem do aço VMO em várias velocidades de corte.

Na usinagem do aço VC131, como ocorreu com o aço VMO, nota-se uma dependência do desgaste de flanco com relação ao material da ferramenta e à velocidade de corte. Como mostra a figura 4.6(a) o desgaste para os dois materiais de ferramenta aumenta com o crescimento da velocidade de corte e o desgaste é mais pronunciado na ferramenta de MD.

O resultado da rugosidade é diferente para cada material de ferramenta, figura 4.6(b). Na usinagem com PCBN a rugosidade ficou em torno de 0,25 $\mu \mathrm{m}$. 
Na usinagem com MD obteve-se um único valor de rogosidade para a velocidade de $60 \mathrm{~m} / \mathrm{min}(0,2 \mu \mathrm{m})$ e um único ponto para $180 \mathrm{~m} / \mathrm{min}(0,3 \mu \mathrm{m})$.

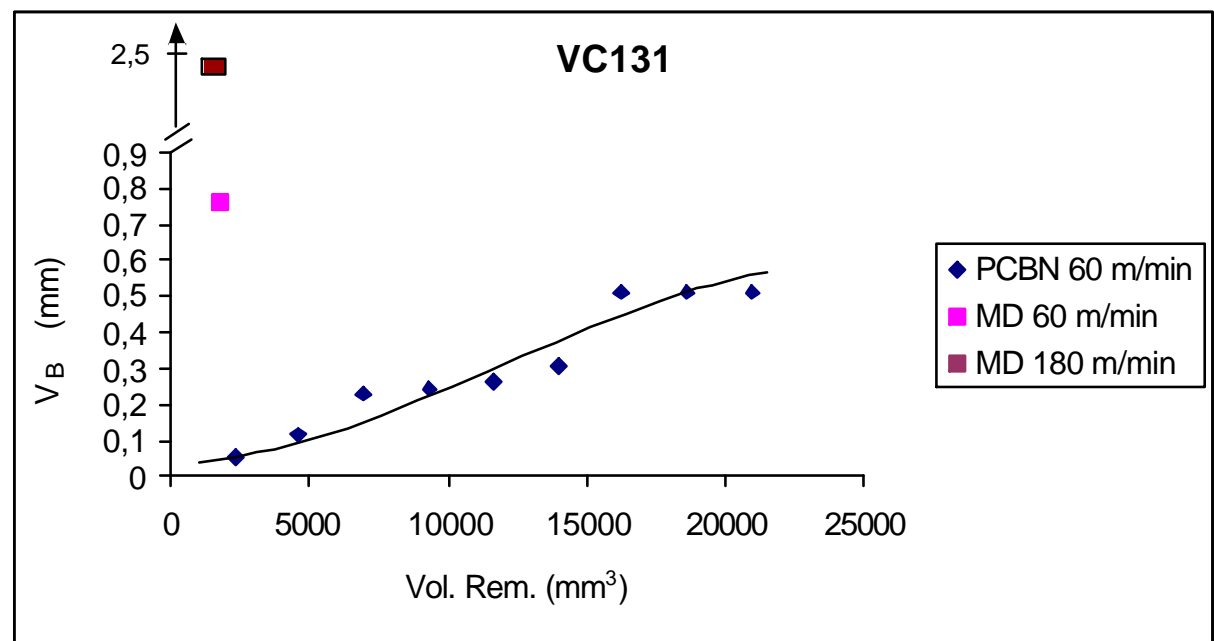

(a) Tendência de desgaste de flanco

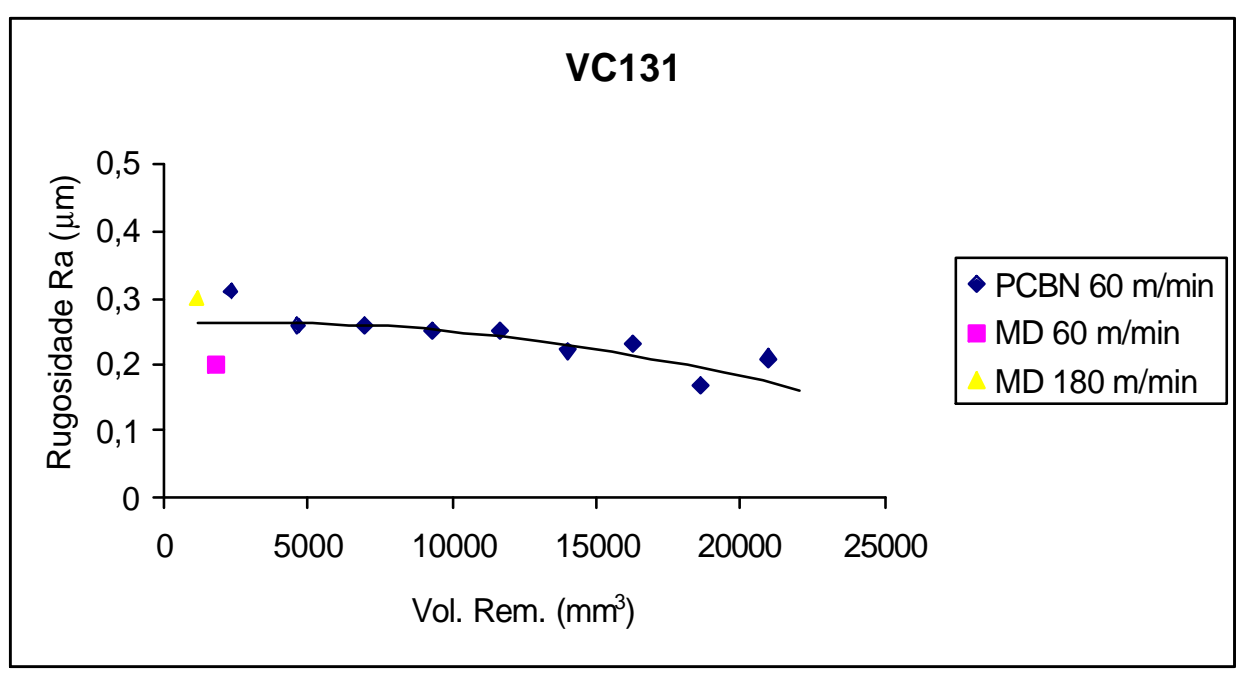

(b) Rugosidade Ra

Figura 4.6 - Gráficos de desgaste de flanco e de rugosidade superficial na usinagem do aço VC131 em várias velocidades de corte.

4.1.3 - Influência do avanço e da velocidade de corte no desgaste do aço $\mathrm{H} 13$

Uma terceira série de ensaios foi realizada com um único material de peça (H13) e um único material de ferramenta (MD), variando o avanço e a velocidade de corte. 
O desgaste de flanco mostra-se diretamente proporcional à velocidade de corte, figura 4.7(a), como era esperado. Quanto ao avanço, não se pode visualizar uma tendência clara, devido ao baixo número de pontos.

$\mathrm{Na}$ figura 4.7(b) pode-se observar que as maiores rugosidades ocorreram com o avanço de $0,1 \mathrm{~mm} /$ dente, independente da velocidade de corte.

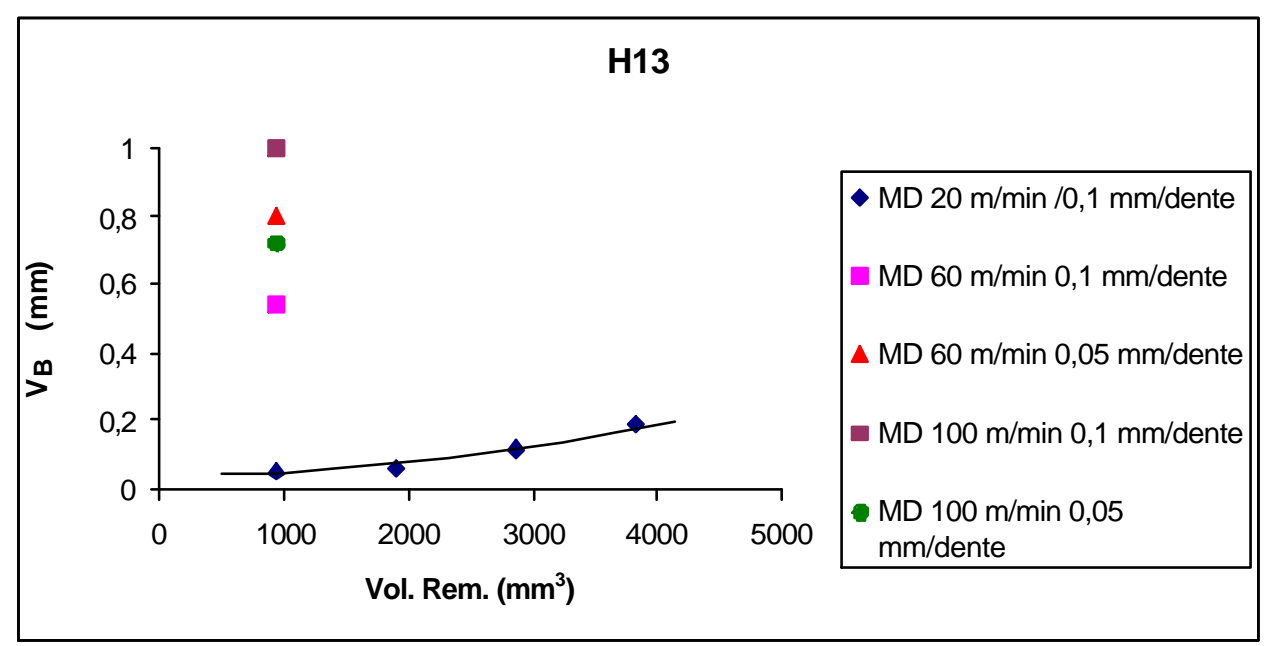

(a) Tendência de desgaste de flanco

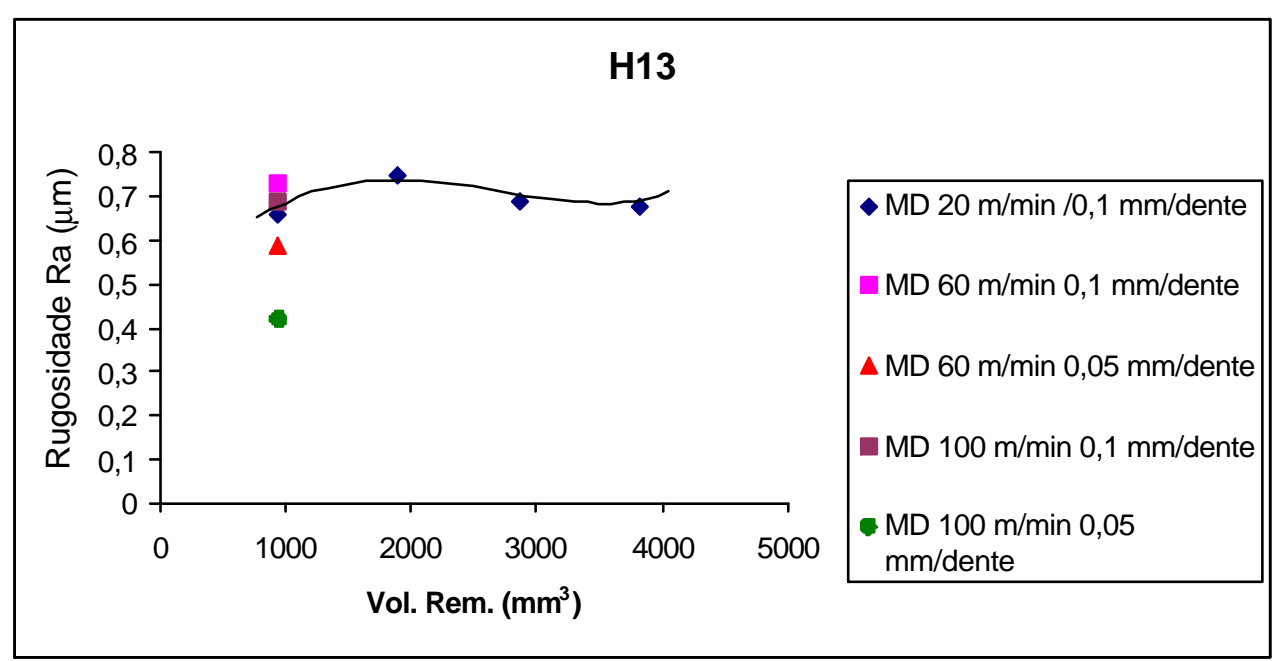

(b) Rugosidade Ra

Figura 4.7 - Desgaste e rugosidade do aço H13 com ferramenta de MD com variação da velocidade de corte e do avanço.

4.1.4 - Resumo dos resultados sobre medição de desgaste e rugosidade superficial

Da primeira série de experimentos, onde foram mantidos constantes os parâmetros de usinagem (velocidade de corte, profundidade e avanço), pode-se 
observar a influência do material da peça no desgaste das ferramenta de corte. Os maiores valores de desgaste foram observados para o material VC 131 (cerca de $0,5 \mathrm{~mm}$ para $23.000 \mathrm{~mm}^{3}$ ) independentemente do material da ferramenta. Da mesma forma, os menores valores foram encontrados para o VMO (cerca de 0,3 $\mathrm{mm}$ para $38.000 \mathrm{~mm}^{3}$ ). Apenas na usinagem do VC131 o desgaste de flanco segue uma tendência de crescimento uniforme. Nos demais materiais há um desgaste inicial que se mantém relativamente estável. Para as ferramentas de MD o desgaste de flanco atinge altos valores já nos primeiros passes (cerca de 0,5 a 0,8 $\mathrm{mm})$.

A rugosidade deixada pela ferramenta de PCBN, ao longo dos ensaios, apresenta oscilação para os três aços, com uma tendência de queda para o H13 e o VC131 e uma tendência de alta para o VMO. Valores médios em torno de 0,25 $\mu \mathrm{m}$ Ra. Apesar dos poucos pontos disponíveis, a rugosidade obtida na usinagem com as ferramentas de MD apresenta valores semelhantes aos obtidos na usinagem com PCBN.

$\mathrm{Na}$ segunda série de experimentos pode-se observar o efeito da variação da velocidade de corte sobre o desgaste de flanco das ferramentas. De forma geral, o desgaste aumenta com a velocidade de corte. As ferramentas de PCBN apresentam os menores desgaste e se comportam de uma forma estável durante os vários passes. Por outro lado, nas ferramentas de MD o desgaste foi acelerado, atingindo valores elevados. Nota-se também que o MD é mais sensível ao aumento da velocidade de corte.

Os valores de rugosidade obtidos nestes experimentos foram semelhantes para as dois materiais de ferramenta (cerca de $0,25-0,3 \mu \mathrm{m} \mathrm{Ra}$ ).

A terceira série de experimentos foi realizada somente com o aço H13 e ferramentas de MD, variando-se o avanço e a velocidade de corte. Procura-se observar a influência do avanço e da velocidade corte no desgaste de flanco. O desgaste mostrou-se mais dependente da velocidade de corte do que do avanço. $\mathrm{O}$ desgaste foi maior nas maiores velocidades (cerca de 0,7 a 1,0 mm). Por outro lado a rugosidade é mais influenciada pelo avanço. As maiores rugosidades foram obtidas com o avanço de $0,1 \mathrm{~mm} /$ dente (cerca de $0,7 \mu \mathrm{m} \mathrm{Ra}$ ). 


\section{2 - Análise de desgaste das ferramentas}

Em uma análise geral dos gráficos de desgaste da seção 4.1 pode-se notar que o desgaste das ferramentas sofreu fortes influências da velocidade de corte e do material da peça. A identificação dos mecanismos e tipos de desgaste que atuaram sobre as ferramentas é efetuada com base em fotografias feitas em microscópio eletrônico de varredura, as quais revelam detalhes das ferramentas desgastadas.

A apresentação dos dados é feita de acordo com as três séries de experimentos realizados.

\subsection{1 - Apresentação e descrição das ferramentas desgastadas}

A primeira série de experimentos inicia-se com a usinagem do aço H13, com uma velocidade de corte de $60 \mathrm{~m} / \mathrm{min}$, avanço de $0,02 \mathrm{~mm} /$ dente e profundidade de usinagem de $1 \mathrm{~mm}$, onde observou-se desgastes diferentes para cada ferramenta (PCBN e MD).

A figura 4.8(a) mostra uma visão geral da aresta de corte desgastada de uma ferramenta de PCBN, onde pode-se observar que o desgaste ocorreu ao longo do flanco da ferramenta, caracterizando o desgaste de flanco. Não se nota indícios de desgaste de cratera sobre a superfície de saída.

Com uma ampliação da ponta da ferramenta, figura 4.8(b), observa-se sinais de abrasão e a presença de uma trinca perpendicular a direção da velocidade de corte.

$\mathrm{Na}$ ferramenta de MD, figura 4.9(a), verifica-se que o desgaste também ocorreu na aresta de corte secundária de corte, além da aresta primária. Neste experimento também não foi encontrado indícios de desgaste de cratera. Com a região desgastada ampliada, figura 4.9(b), pode-se encontrar sinais de adesão, evidências de trinca. 


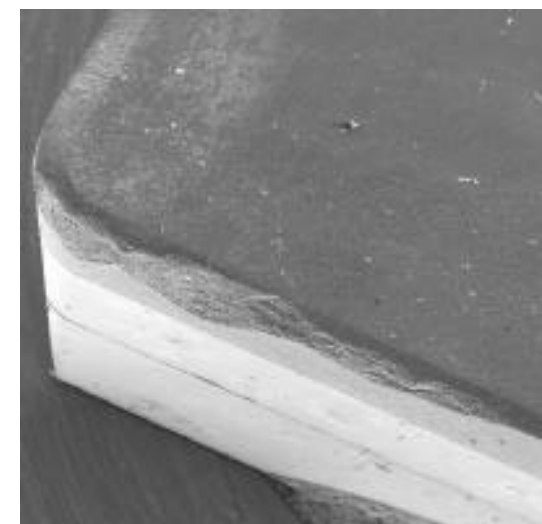

(a)Visão geral da ferramenta $-37 \mathrm{x}$

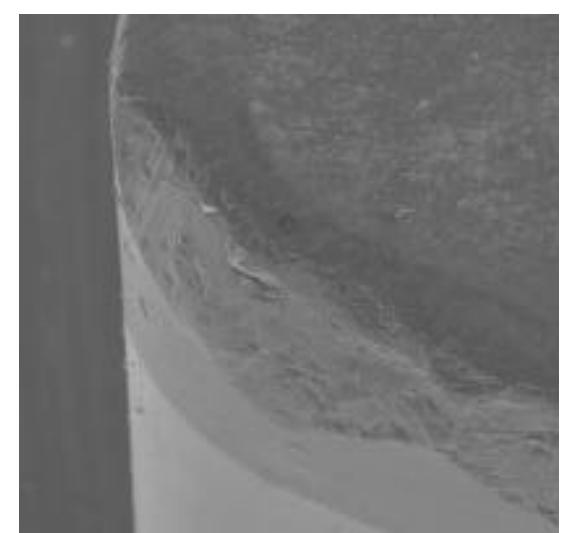

(b) Detalhe da ponta da ferramenta $135 \mathrm{x}$

Figura 4.8 - Ferramenta de PCBN desgastada na usinagem do aço $\mathrm{H} 13$, com a velocidade de corte de $60 \mathrm{~m} / \mathrm{min}$.

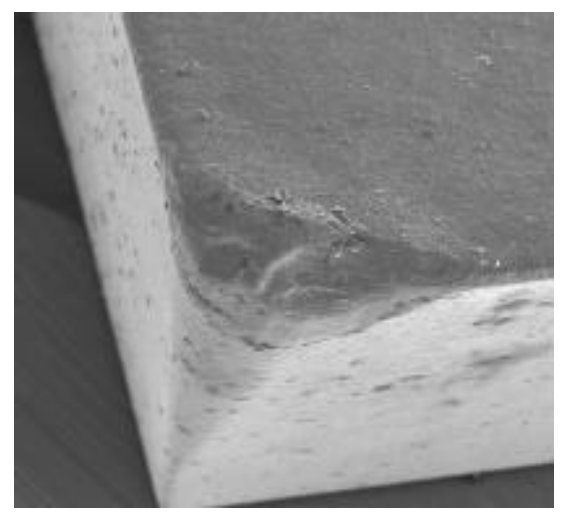

(a)Visão geral da ferramenta $-60 x$

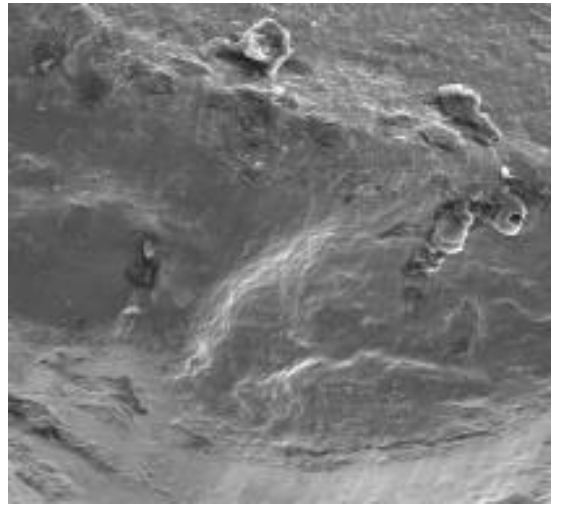

(b) Detalhe do centro da região desgasta - 200x.

Figura 4.9 - Ferramenta de MD desgastada na usinagem do aço H13, com a velocidade de corte de $60 \mathrm{~m} / \mathrm{min}$.

Para o aço VMO, as características de desgaste são diferentes do aço H13 para as duas ferramentas (PCBN e MD). Os parâmetros de corte usados são os mesmos do aço H13 (velocidade de corte de $60 \mathrm{~m} / \mathrm{min}$, avanço de $0,02 \mathrm{~mm} /$ dente e profundidade de usinagem de $1 \mathrm{~mm}$ ).

$\mathrm{Na}$ ferramenta de PCBN observa-se uma única região com o desgaste mais pronunciado (da ordem de $0,3 \mathrm{~mm}$ ), as outras partes da aresta de corte mostra um desgaste mínimo (aproximadamente 0,1 mm), figura 4.10(a). A figura 4.10(b) é uma ampliação da região mais desgastada, onde se encontram indícios de adesão. 
E na figura 4.10(c) observa-se uma pequena região que sofreu abrasão e também nota-se evidências de desgaste de cratera.

Em uma visão geral da ferramenta de $\mathrm{MD}$, figura 4.11(a), nota-se que o desgaste é visivelmente maior que o desgaste da ferramenta de PCBN, figura 4.10(a), já que a ampliação das duas fotos é a mesma.

O desgaste de cratera fica evidente sobre a superfície de saída na figura 4.11(b). Na figura 4.11(c) nota-se a presença de material aderido sobre a aresta secundária de corte, na ponta da ferramenta.

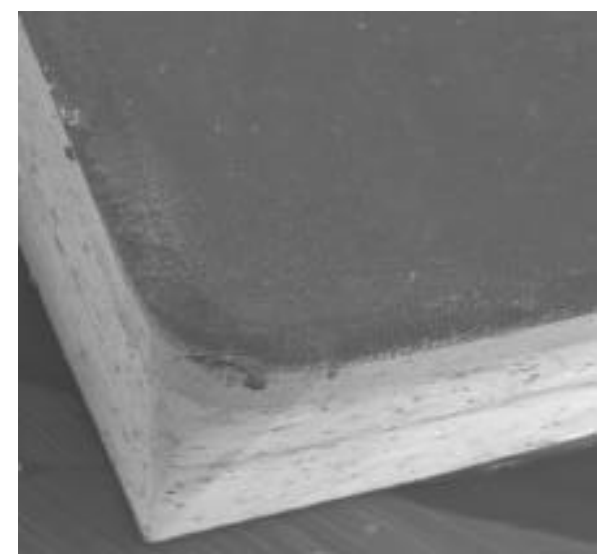

(a)Visão geral da ferramenta - 50x

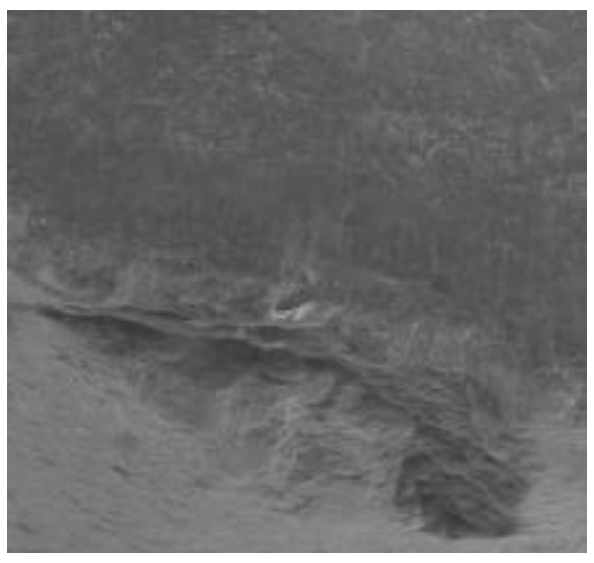

(b) Detalhe da ponta da ferramenta 300x.

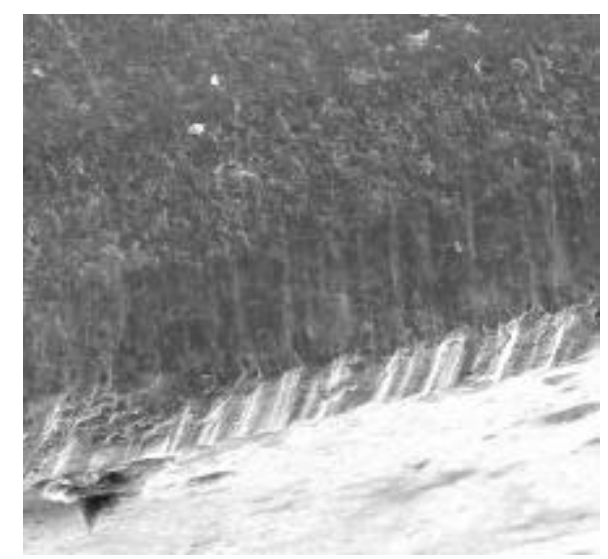

(c) Detalhe mostrando abrasão e indícios de desgaste de cratera.

Figura 4.10 - Ferramenta de PCBN desgastada quando usinando o aço VMO, com a velocidade de corte de $60 \mathrm{~m} / \mathrm{min}$. 


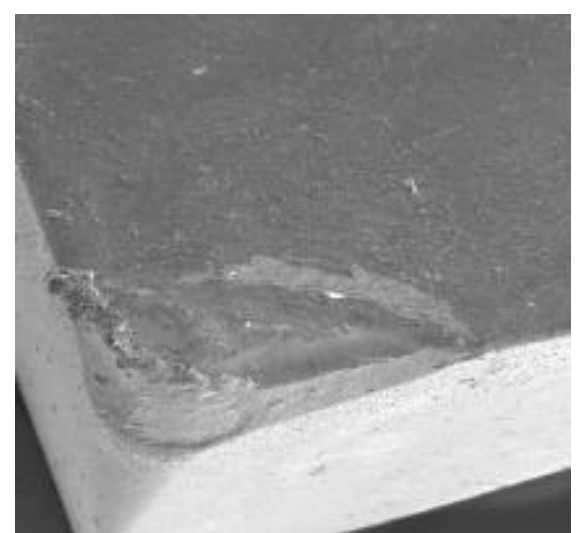

(a)Visão geral da ferramenta - 50x.

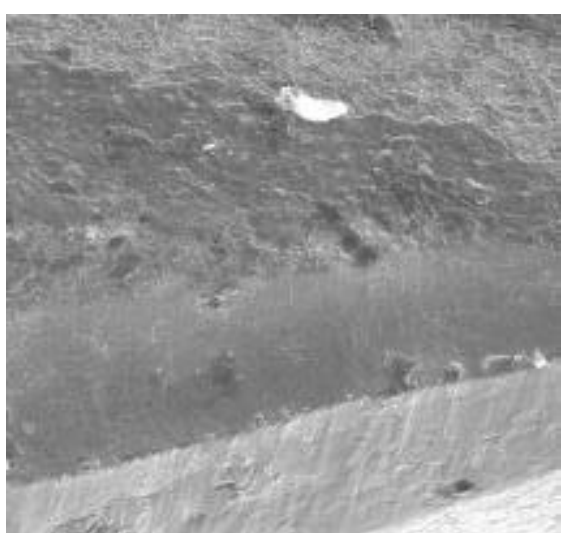

(b) Desgaste de cratera - 200x.

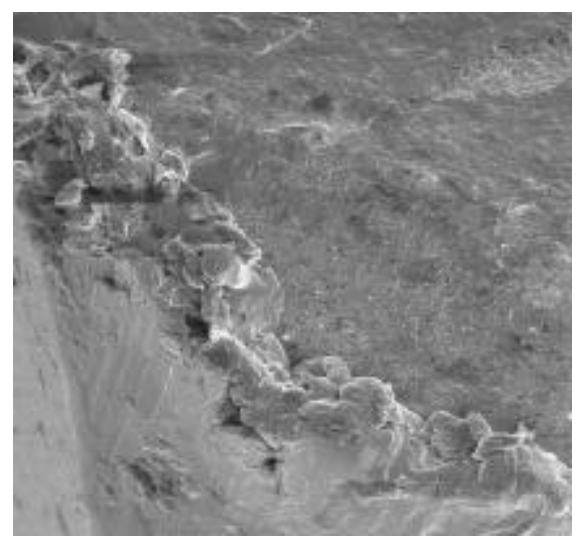

(c) Aresta postiça sobre a aresta da ferramenta.

Figura 4.11 - Ferramenta de MD desgastada quando usinando o aço VMO, com a velocidade de corte de $60 \mathrm{~m} / \mathrm{min}$.

A usinagem do aço VC131 foi realizada com os mesmos parâmetros de corte dos outros materiais usinados (velocidade de corte $60 \mathrm{~m} / \mathrm{min}$, avanço 0,02 $\mathrm{mm} /$ dente e profundidade de usinagem $1 \mathrm{~mm}$ ).

Para a usinagem do aço VC131, o desgaste da ferramenta de PCBN produziu uma superfície plana, sobre a aresta de corte, figura 4.12(a), característico do desgaste de flanco. Na figura 4.12(b), observa-se alguns sinais de abrasão e uma forte adesão.

Para a ferramenta de MD quando usinado o mesmo aço observa-se que o desgaste da aresta secundária de corte foi bastante elevado, figura 4.13(a). Pode-se notar também marcas de abrasão na mesma aresta. Em uma ampliação da aresta secundária encontra-se evidências de adesão, figura 4.13(b). Na figura 4.13(c), ampliação da ponta da aresta, também encontra-se sinais de adesão. 


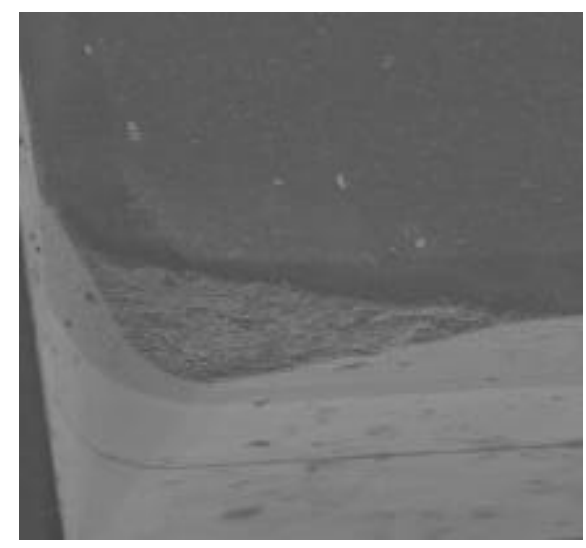

(a) Visão geral da ferramenta - 70x.

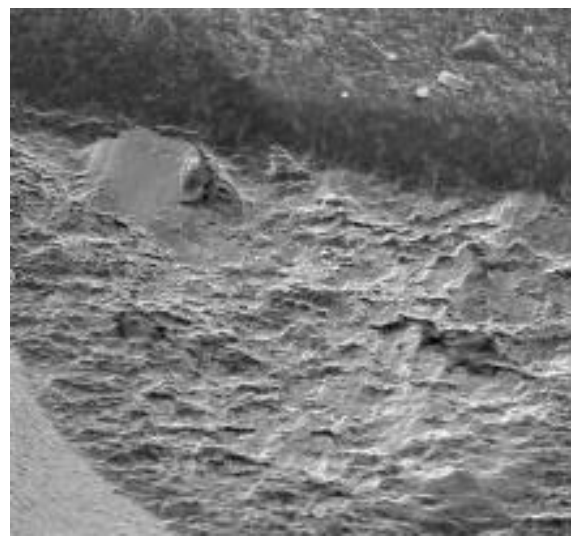

(b) Sinais de abrasão e adesão250x.

Figura 4.12 - Ferramenta de PCBN desgastada quando usinado o aço VC131, com a velocidade de corte de $60 \mathrm{~m} / \mathrm{min}$.

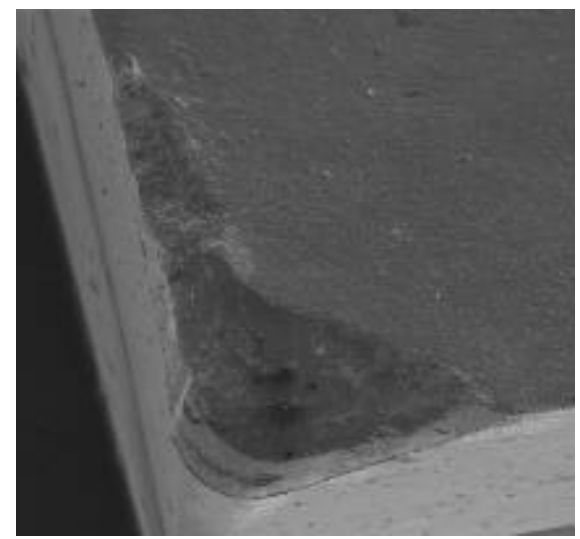

(a) Visão geral da ferramenta 50x.

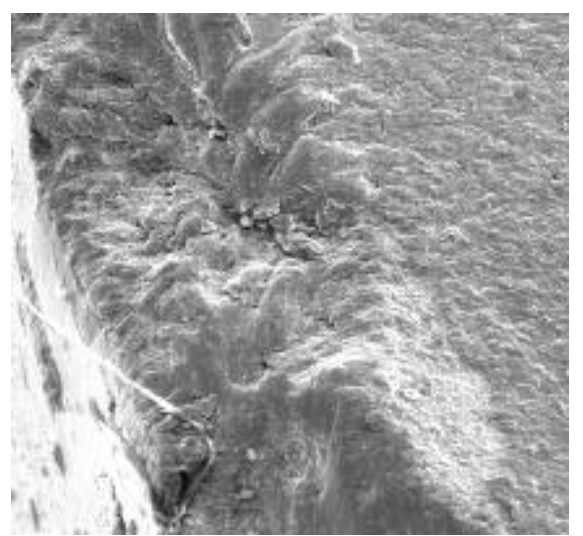

(b) Indícios de adesão na aresta secundária de corte $-200 x$.

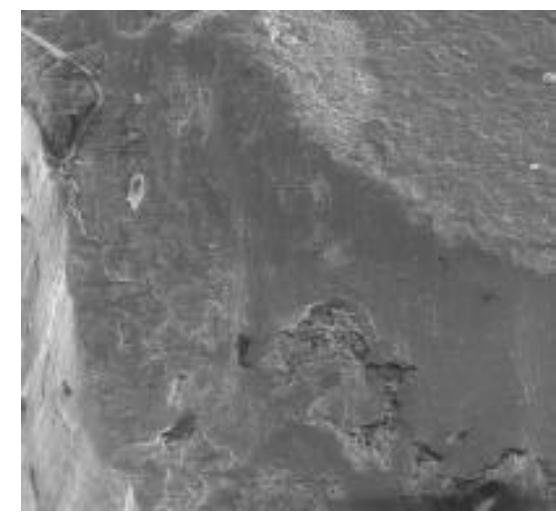

(c) Evidências de adesão na região central da ferramenta.

Figura 4.13 - Ferramenta de MD desgasta quando usinando o aço VC131 com a velocidade de corte de $60 \mathrm{~m} / \mathrm{min}$. 
Uma série curta de experimentos foi realizada para o aço H13, com os seguintes parâmetros de usinagem: velocidade de $100 \mathrm{~m} / \mathrm{min}$, avanço $0,02 \mathrm{~mm} /$ dente e profundidade de usinagem de $1 \mathrm{~mm}$.

Chama a atenção na ferramenta de PCBN uma trinca relativamente grande (com aproximadamente metade do comprimento da região desgastada) perpendicular à direção da velocidade de corte, figura 4.14(a). A trinca pode ser observada com mais detalhes na figura 4.14(b), onde também encontra-se indícios de abrasão e adesão.

Na ferramenta de MD observa-se que o desgaste ocorreu tanto na aresta principal de corte quanto na secundária, figura 4.15(a). Uma pequena trinca pode ser observada na figura 4.15(b) e também evidências de adesão.

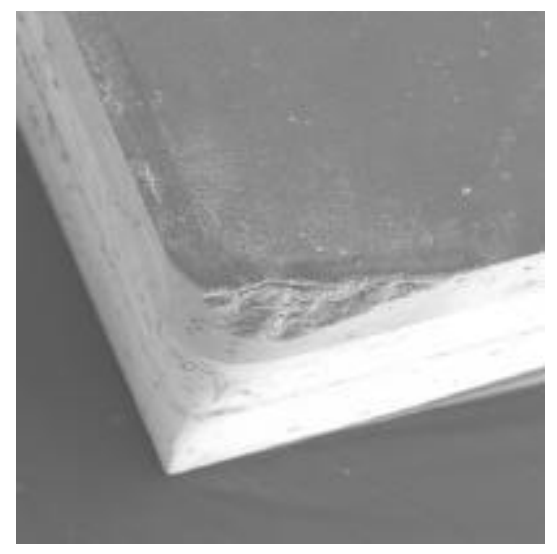

(a) Visão geral da ferramenta - 50x.

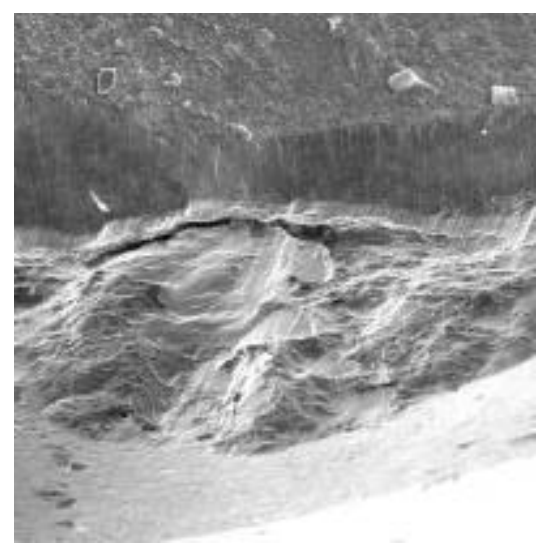

(b) Detalhe da trinca - 200x.

Figura 4.14 - Ferramenta de PCBN desgastada quando usinando o aço $\mathrm{H} 13$, com a velocidade de corte de $100 \mathrm{~m} / \mathrm{min}$. 


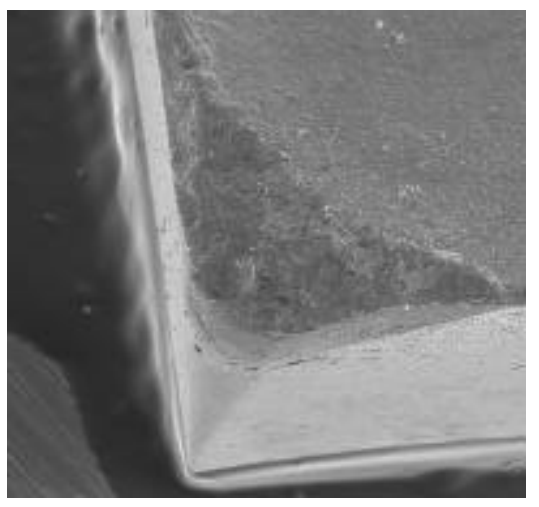

(a) Visão geral da ferramenta - 50x.

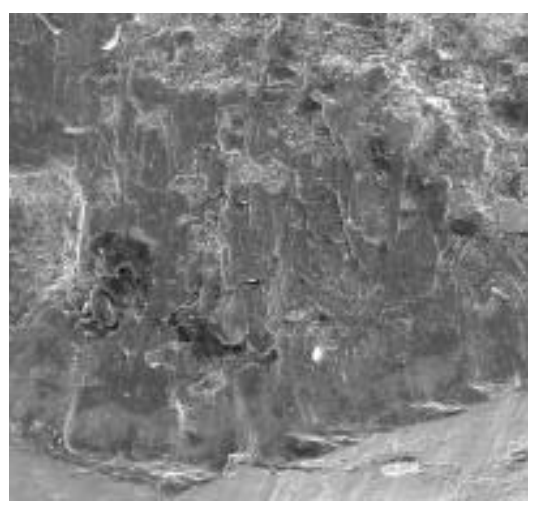

(b) Detalhe de uma pequena trinca no centro da figura $-200 \mathrm{x}$

Figura 4.15 - Ferramenta de MD desgastada quando usinando o aço $\mathrm{H} 13$, com a velocidade de corte de $100 \mathrm{~m} / \mathrm{min}$.

$\mathrm{Na}$ terceira série de ensaios foram utilizadas as ferramentas de MD na usinagem dos três materiais (H13, VMO e VC131), com os seguintes parâmetros de corte: velocidade de corte $180 \mathrm{~m} / \mathrm{min}$, avanço $0,02 \mathrm{~mm} /$ deste e profundidade de usinagem de $1 \mathrm{~mm}$.

A figura 4.16(a) mostra que o desgaste ocorreu na aresta principal de corte e na aresta secundária mais ou menos na mesmas proporções. Também pode-se observar uma trinca, na aresta principal, cujo o comprimento é praticamente o mesmo da região desgastada. Na figura 4.16(b) observa-se parte da trinca, que perpendicular a direção da velocidade de corte. Próximo à trinca encontra-se sinais de abrasão e logo acima da mesma indícios de adesão. Na aresta secundária de corte pode-se encontrar também indícios de adesão, figura 4.16(c).

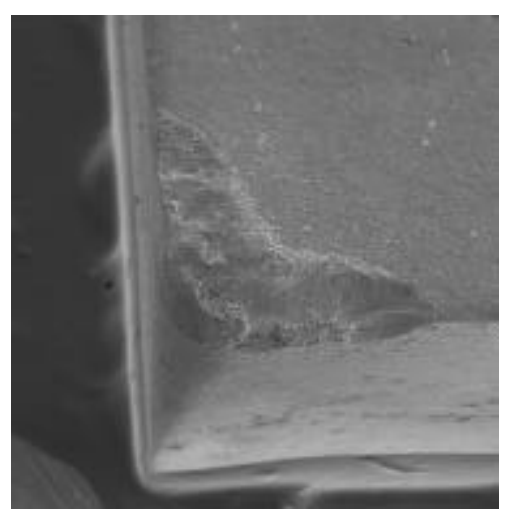

(a) Visão geral da ferramenta $50 x$.

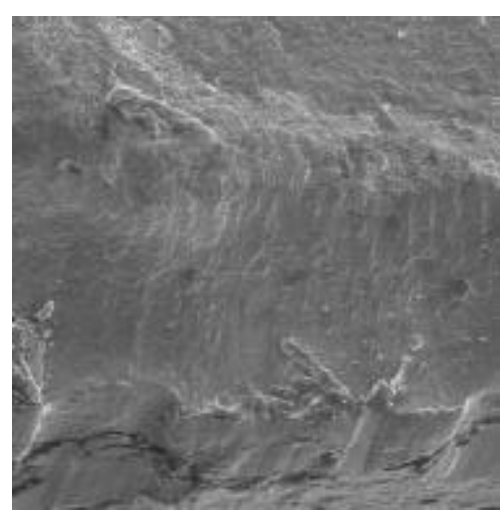

(b) Detalhe de uma trinca na aresta de corte principal - 200x. 


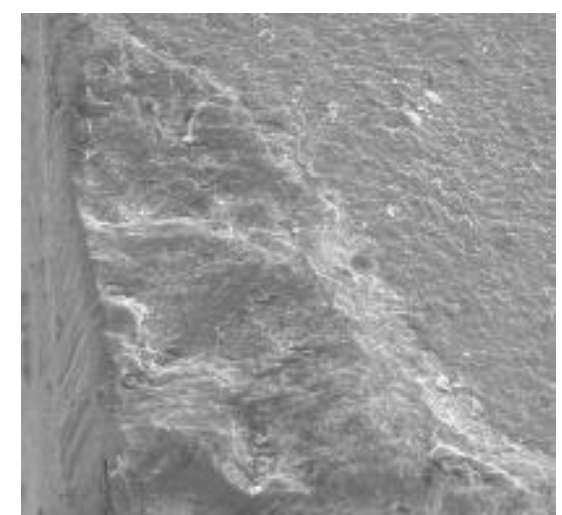

(c) Indícios de adesão na aresta de corte secundária - 150x.

Figura 4.16 - Ferramenta desgastada na usinagem do aço $\mathrm{H} 13$, com a velocidade de corte de $180 \mathrm{~m} / \mathrm{min}$.

$\mathrm{Na}$ usinagem do aço VMO o desgaste concentrou na aresta principal de corte, figura 4.17(a). Na figura 4.17(b), parte superior da região desgasta, encontra-se evidências de adesão. Na parte inferior da região desgastada pode-se observar evidências de abrasão e adesão, figura 4.17(c).

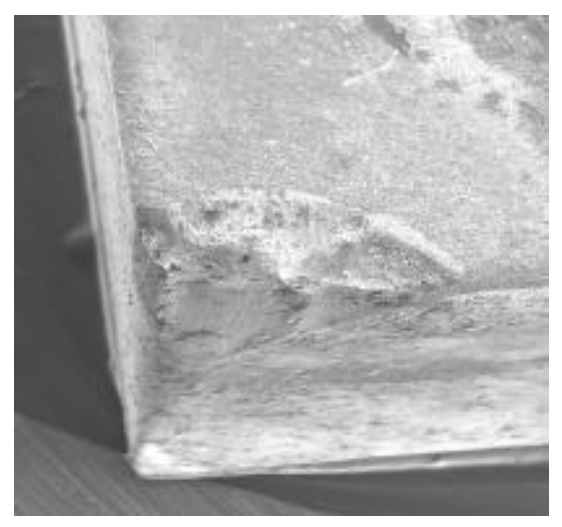

(a) Visão geral da ferramenta - 50x.

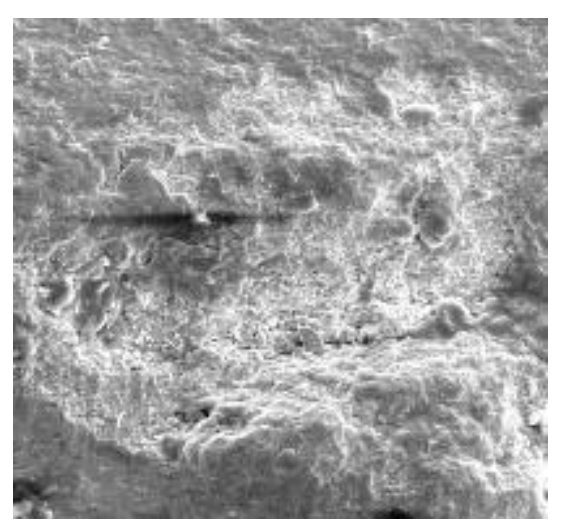

(b) Evidências de adesão - 300x. 


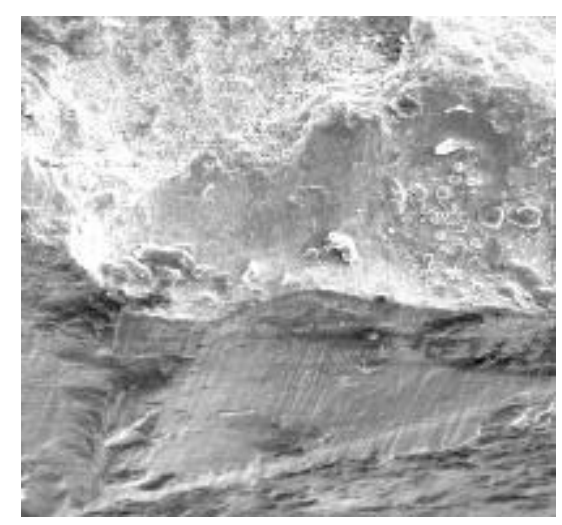

(c) Evidências de abrasão e adesão - 200x.

Figura 4.17 - Ferramenta de MD desgastada na usinagem do aço $\mathrm{VMO}$, com a velocidade de corte de $180 \mathrm{~m} / \mathrm{min}$.

$\mathrm{Na}$ usinagem do aço VC131 obteve-se o desgaste mais severo, figura 4.18(a). O desgaste ocorreu em toda a espessura do inserto (cerca de 2,4 mm). Na figura 4.18(b) observa-se um detalhe da região desgastada, onde nota-se uma abrasão muito forte e indícios de do material usinado derretido.

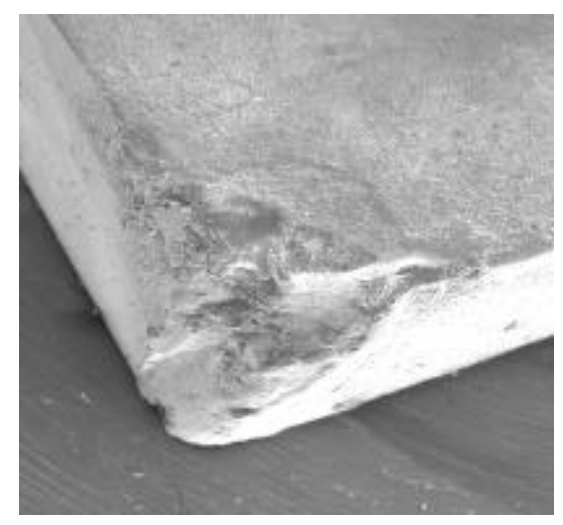

(a) Visão geral da ferramenta $35 \mathrm{x}$.

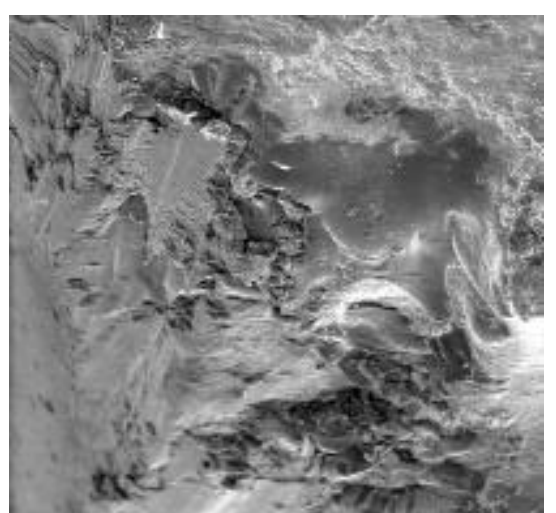

(b) Evidências de forte abrasão 100x

Figura 4.18 - Ferramenta de MD desgastada quando usinando o aço VC131, com a velocidade de corte de $180 \mathrm{~m} / \mathrm{min}$.

Foi também realizado um experimento inicial, de caráter exploratório, com ferramenta de PCBN e usando fluido de corte (emulsão 3\%). O experimento consistiu da usinagem do aço H13 com os seguintes parâmetros de corte: 
velocidade de corte de $60 \mathrm{~m} / \mathrm{min}$, avanço de $0,02 \mathrm{~mm} /$ dente e profundidade de usinagem de $1 \mathrm{~mm}$.

A figura 4.19(a) mostra que boa parte da ferramenta sofreu um forte lascamento em apenas dois passes de usinagem, inviabilizando o uso da ferramenta. A figura 4.19(b) revela trincas na superfície desgastada.

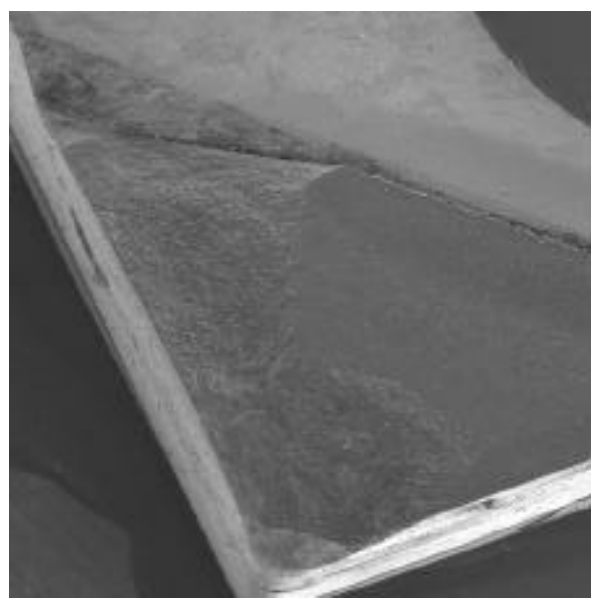

(a) Visão geral da ferramenta $-24 x$.

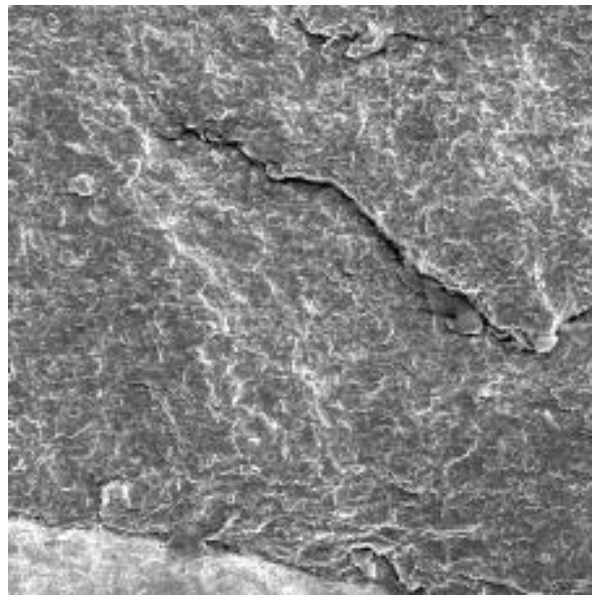

(b) Detalhe de uma trinca na região desgastada $-175 \mathrm{x}$

Figura 4.19 - Ferramenta de PCBN que sofreu severo lascamento devido o uso de fluido de corte.

\subsection{2 - Resumo sobre a análise de desgaste}

O desgaste ocorreu de forma diferente para cada material usinado, apresentando mecanismos e tipos de desgaste distintos. O desgaste de flanco é dominante em todas as ferramentas analisadas, independente do material da ferramenta, material usinado ou velocidade de corte utilizada.

A abrasão é comum para todos os materiais usinados e em todas as velocidades de corte utilizadas, apenas variando de intensidade. A abrasão cresce com a velocidade de corte, tornando-se muito forte na velocidade de $180 \mathrm{~m} / \mathrm{min}$. A temperatura de corte, nesta velocidade é suficientemente alta para diminuir a dureza do material da ferramenta e facilitar a ação das partículas abrasivas. O material da peça tem influência decisiva, pode-se dizer que no fresamento do aço VC131 o tipo mais evidente de desgaste foi o abrasivo. Isto pode ser atribuído á 
maior presença de carbetos (partículas duras) na matriz deste aço, se comparado com os demais materiais usinados, conforme figuras 3.2.

De forma geral os mecanismos de desgaste de abrasão e de adesão estão sempre juntos, nas ferramentas analisadas, apenas alternam de intensidade dependendo da combinação entre material usinado/ferramenta e da velocidade de corte. A combinação entre material usinado/ferramenta pode resultar em maior ou menor facilidade de adesão (Konig, et al., 1993).

$\mathrm{O}$ mecanismo de abrasão esteve sempre presente provavelmente devido à presença de partículas duras na matriz dos materiais usinados, que agem como abrasivos na ferramenta. No MD, devido à sua menor dureza este mecanismo é mais evidente do que no PCBN, em altas velocidades de corte (no caso 180 $\mathrm{m} / \mathrm{min}$ ). Com o aumento da velocidade de corte, a abrasão destas partículas é mais severa (Ohtani, et al., 1988).

Encontra-se indícios de desgaste de cratera na maioria das ferramentas. A formação de cratera mais clara foi na usinagem do aço VMO, com ferramenta de MD e velocidade de corte de $60 \mathrm{~m} / \mathrm{min}$. Nesta condição nota-se a presença de aresta postiça.

Um fato que chama a atenção é a geração de trincas na ferramentas de MD e PCBN quando usinando o aço H13, em todas as velocidade de corte. Estas são em planos paralelos à superfície de saída e aumentam de tamanho com a velocidade de corte. Nas ferramentas de PCBN as trincas são maiores do que nas ferramentas de $\mathrm{MD}$, se comparadas na mesma velocidade de corte. $\mathrm{O}$ aparecimento de trincas está, segundo a literatura (Modern, 1994), ligado à fadiga mecânica ou térmica. No fresamento de topo de materiais endurecidos ambas as solicitações estão presentes e isto pode ter sido agravado pelo fato de tanto o CBN quanto o MD serem prensados biaxialmente formando camadas paralelas à superfície de saída. 


\section{3 - Micrografias}

Micrografias da região usinada dos três materiais não revelam a presença de trincas na camada abaixo da superfície usinada, conforme mostrado na figura 4.20 .
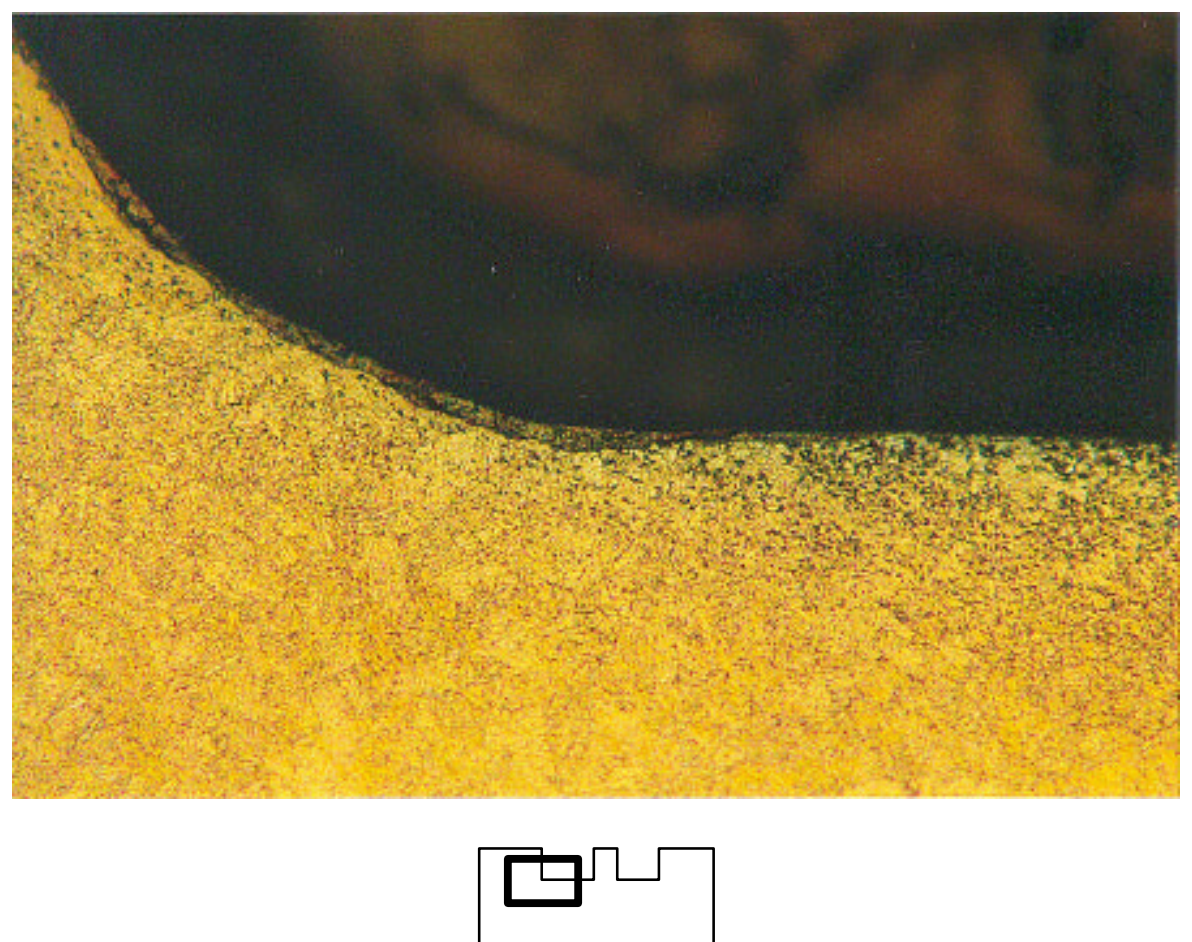

(a) Camada escura sobre o perfil usinado para o aço H13 - 230x. 

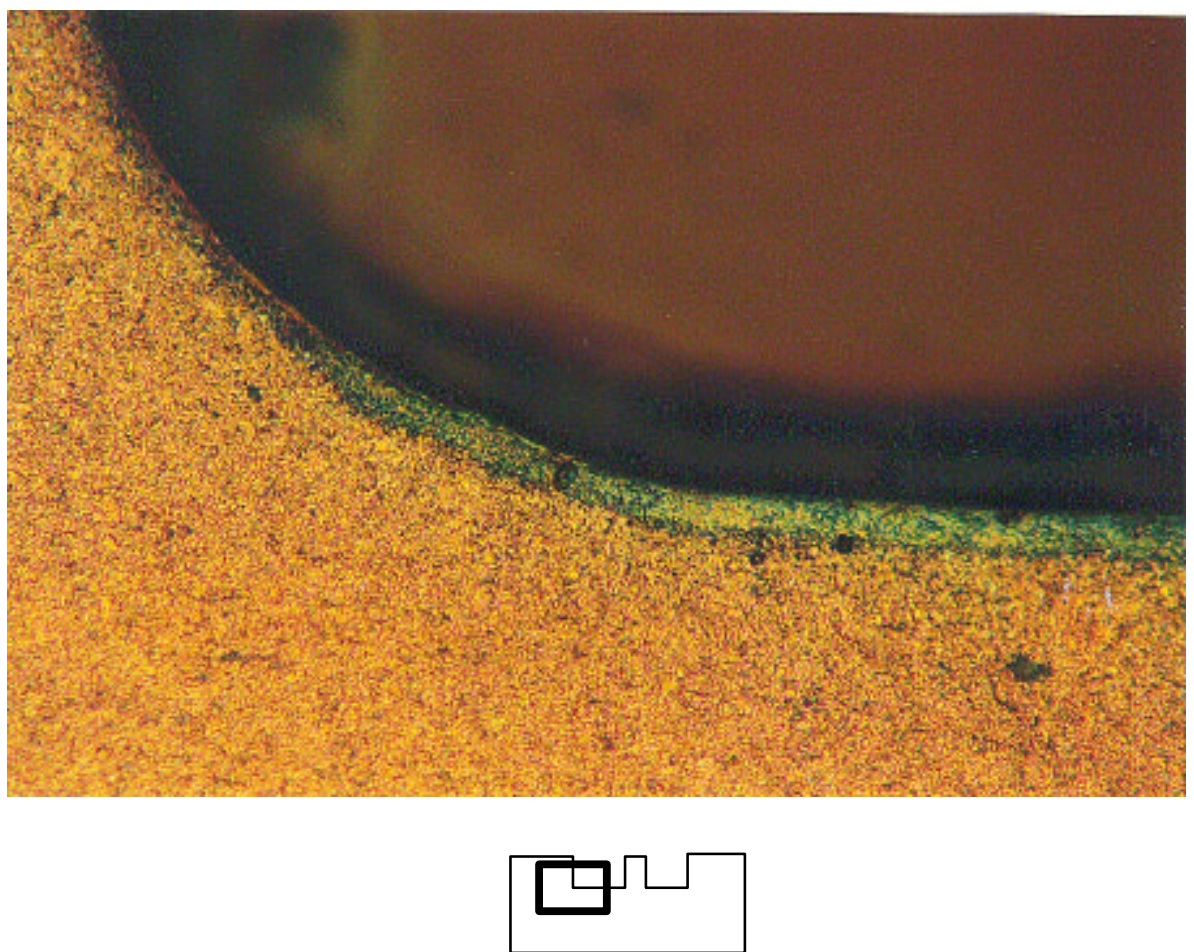

(b) A camada esverdeada para o aço VMO - 230x.
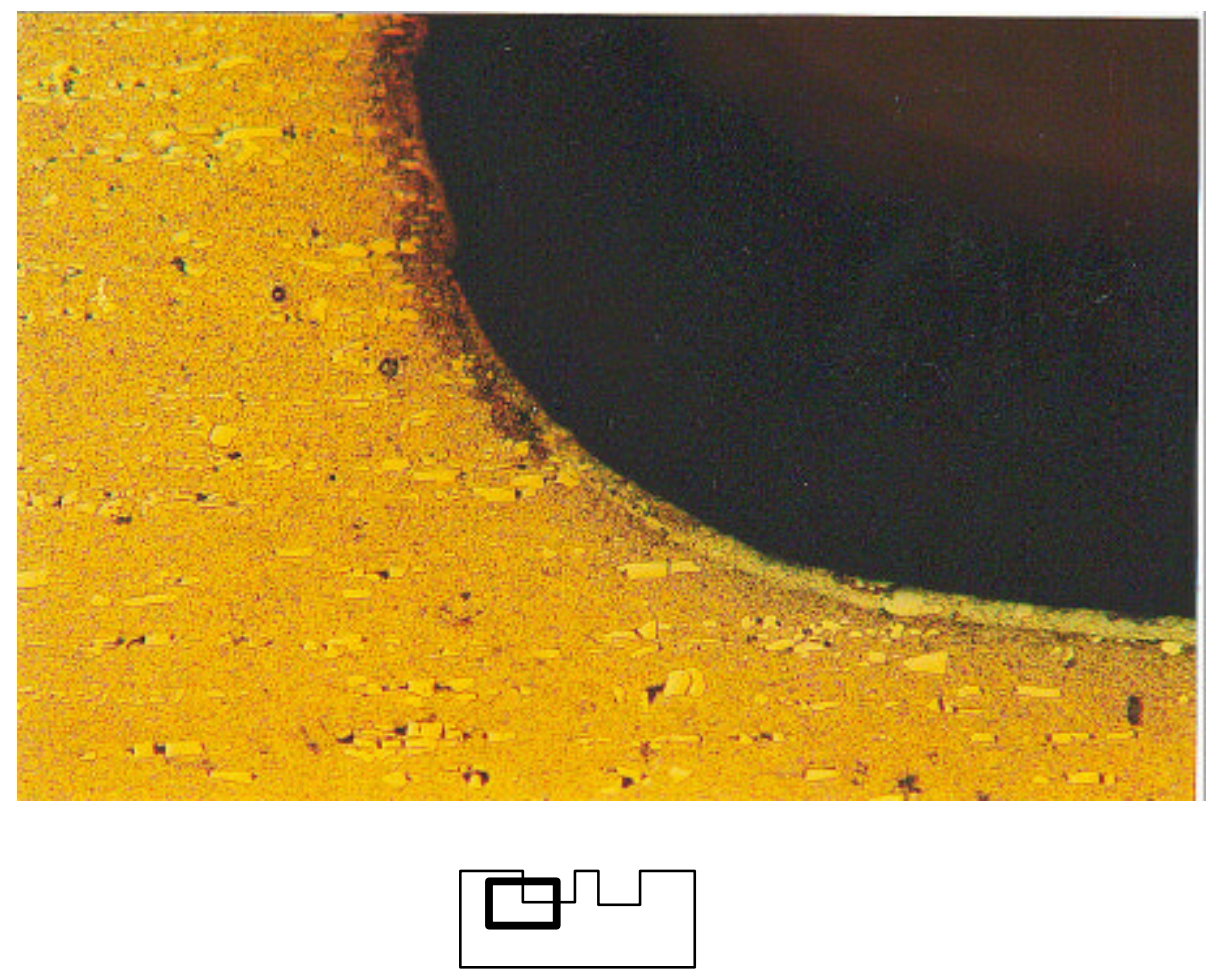

(c) Camada branca sofre o perfil usinado para o aço VC131 - 230x.

Figura 4.20 -Microestrutura depois de usinada. 
Nas fotografias da figura 4.20 nota-se a presença de uma camada próxima á superfície usinada, cuja aparência é diferente daquela observada no interior do material. No aço VC131 a camada é clara enquanto que nos outros materiais esta é mais escura que a microestrutura normal. Estas camadas podem ser consequiência de uma alteração na microestrutura do material devido às altas temperaturas e tensões durante o corte.

\subsection{Gráficos de Emissão Acústica}

Dos dados obtidos com a emissão acústica pode-se observar que a velocidade de corte, o material da peça e o material da ferramenta têm influência sobre a emissão acústica.

A quantidade de gráficos de emissão acústica é bastante elevada, por isso são comentados e mostrados gráficos representativos. Para efeito de comparação foi feita a média da voltagem RMS de cada gráfico discutido. O avanço e a profundidade de usinagem são constantes para todas as condições de usinagem discutidas nesta seção (respectivamente $0,02 \mathrm{~mm} /$ dente e $1 \mathrm{~mm}$ ). Cada fator de influência é discutido separadamente a seguir.

\subsection{1 - Influência da velocidade de corte sobre a emissão acústica}

A usinagem do aço $\mathrm{H} 13$, com ferramenta de $\mathrm{MD}$ foi tomado como exemplo do efeito da velocidade de corte.

Na figura 4.21(a) a velocidade de corte usada foi de $60 \mathrm{~m} / \mathrm{min}$ e a média da voltagem RMS foi de $0,59 \mathrm{~V}$. Na velocidade de $100 \mathrm{~m} / \mathrm{min}$ a média da voltagem RMS foi de 2,0V, figura 4.21(b) e na velocidade de $180 \mathrm{~m} / \mathrm{min}$ a média da voltagem foi $3,35 \mathrm{~V}$, figura 4.21 (c).

Pode-se notar pela analise dos gráficos que a média da voltagem RMS cresce junto com a velocidade de corte. 


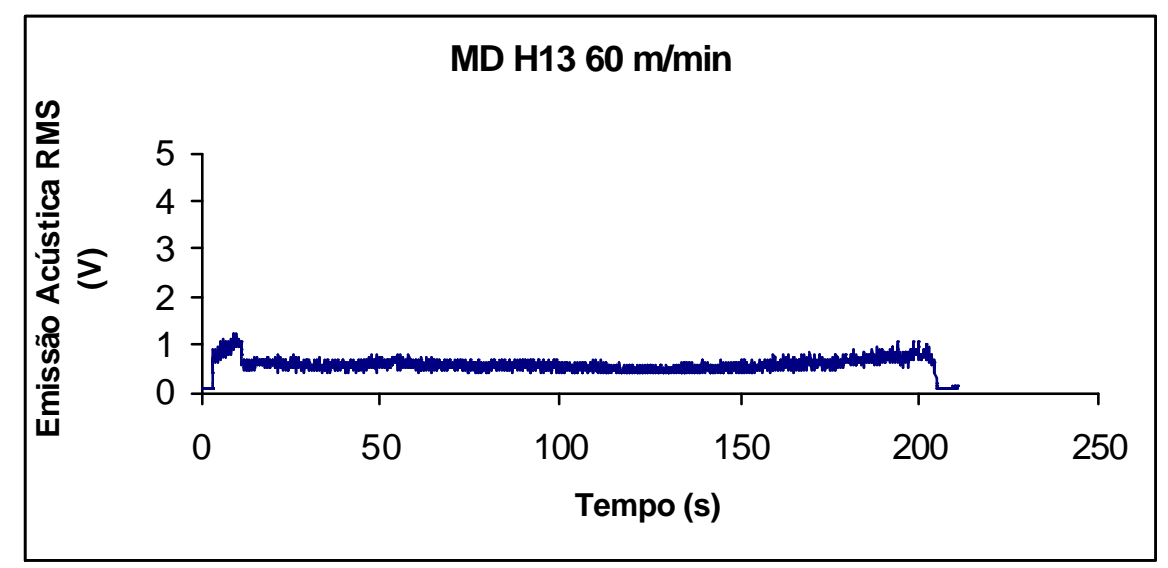

(a) Velocidade de corte $-60 \mathrm{~m} / \mathrm{min}$.

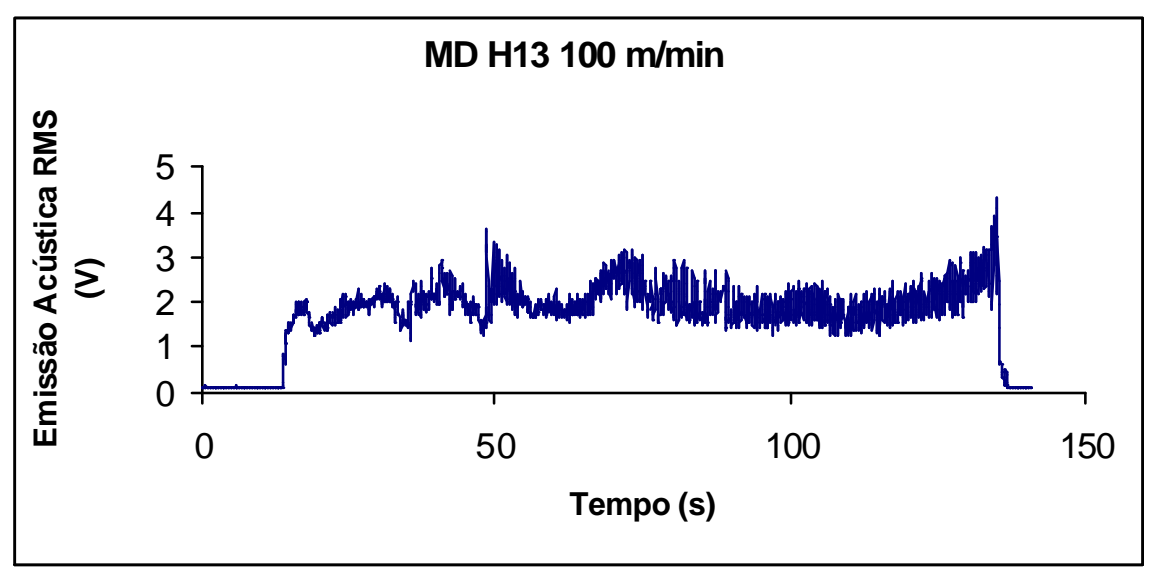

(b) Velocidade de corte $-100 \mathrm{~m} / \mathrm{min}$.

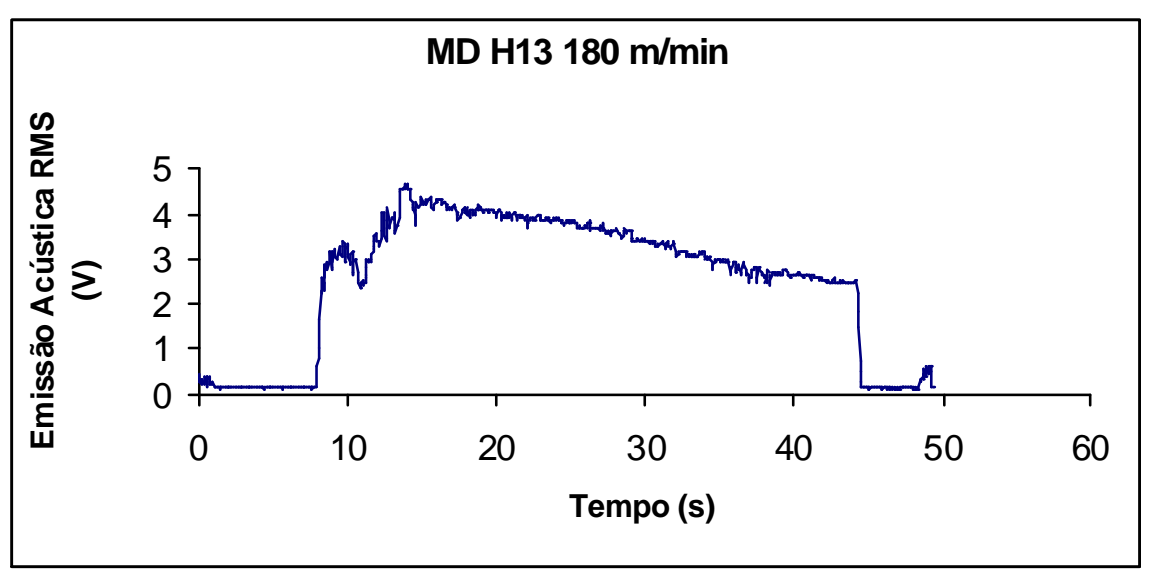

(c) Velocidade de corte $-180 \mathrm{~m} / \mathrm{min}$.

Figura 4.21 -Crescimento da emissão acústica com o aumento da velocidade de corte. 


\subsection{2 - Influência do material da peça sobre a emissão acústica}

A emissão acústica depende do material da peça como pode ser observado nos gráficos abaixo, figura 4.22. Os gráficos referem-se à usinagem com ferramentas de MD e velocidade de corte de $60 \mathrm{~m} / \mathrm{min}$.

$\mathrm{O}$ aço VMO apresentou a maior média de voltagem RMS $(0,99 \mathrm{~V})$ seguido do VC131 (0,90V) e o H13 apresentando a menor média (0,59V).

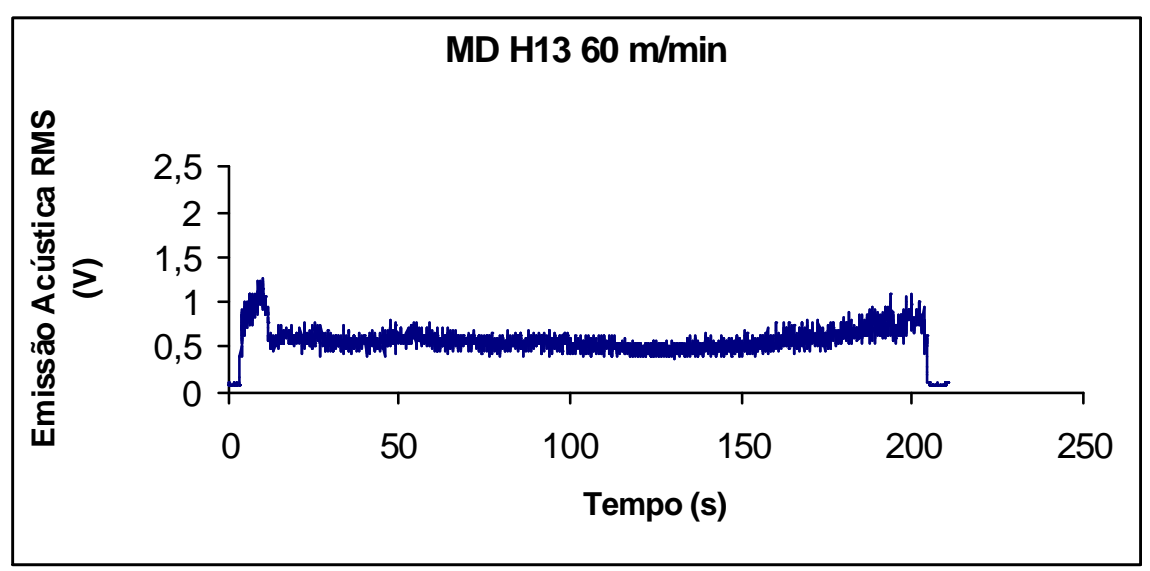

(a) Aço H13.

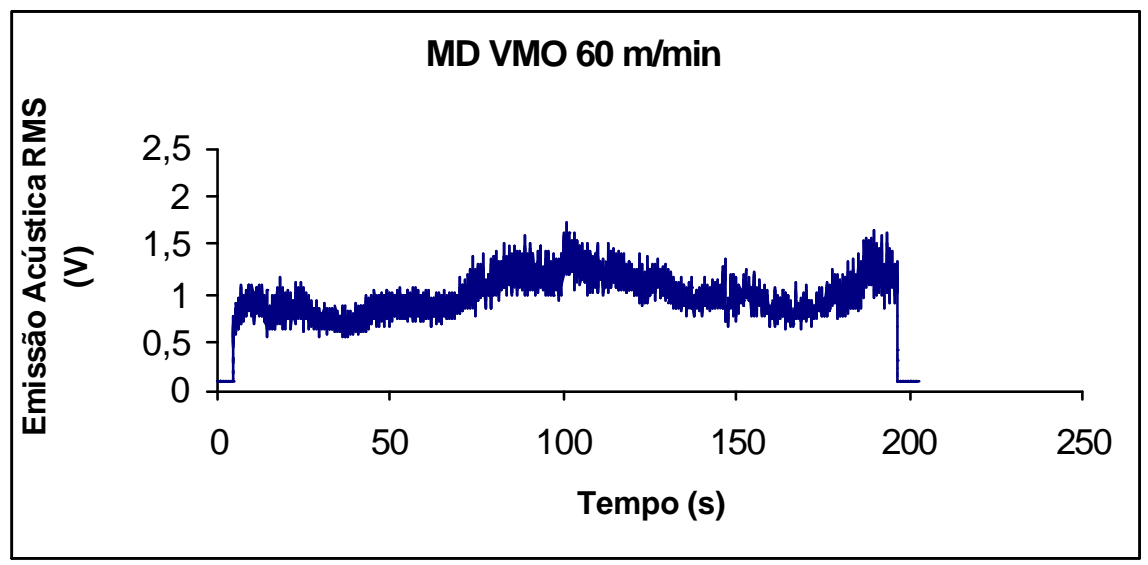

(b) Aço VMO. 


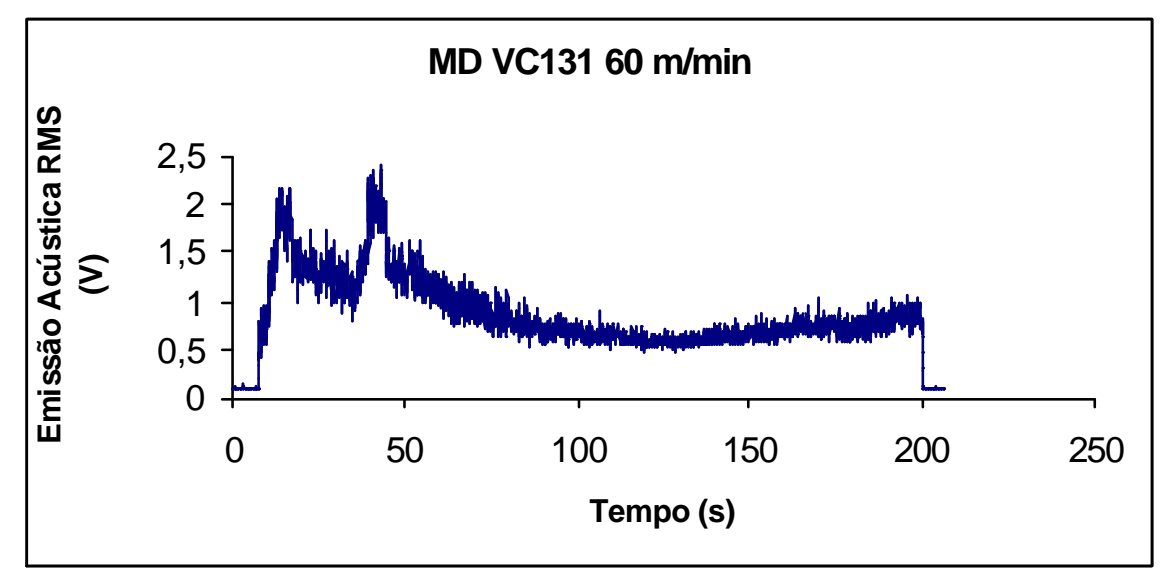

(c) Aço VC131.

Figura 4.22 - Diferentes níveis de emissão acústica, para cada material de usinado, com ferramentas de MD.

\subsection{3 - Influência do material da ferramenta sobre a emissão acústica}

Uma diferença sensível no valor médio da voltagem RMS pode ser observada entre os materiais de ferramenta. Os resultados referem-se à velocidade de corte de $60 \mathrm{~m} / \mathrm{min}$, para os dois materiais de ferramenta e para os três materiais de peça.

Para as ferramentas de PCBN os valores da voltagem média RMS são diferentes para cada material de peça, porém próximos, $0,56 \mathrm{~V}$ para o $\mathrm{H} 13,0,59 \mathrm{~V}$ para o VMO e 0,57 para o VC131. Na figura 4.23 são mostrados os gráficos de emissão acústica para cada material de peça. 


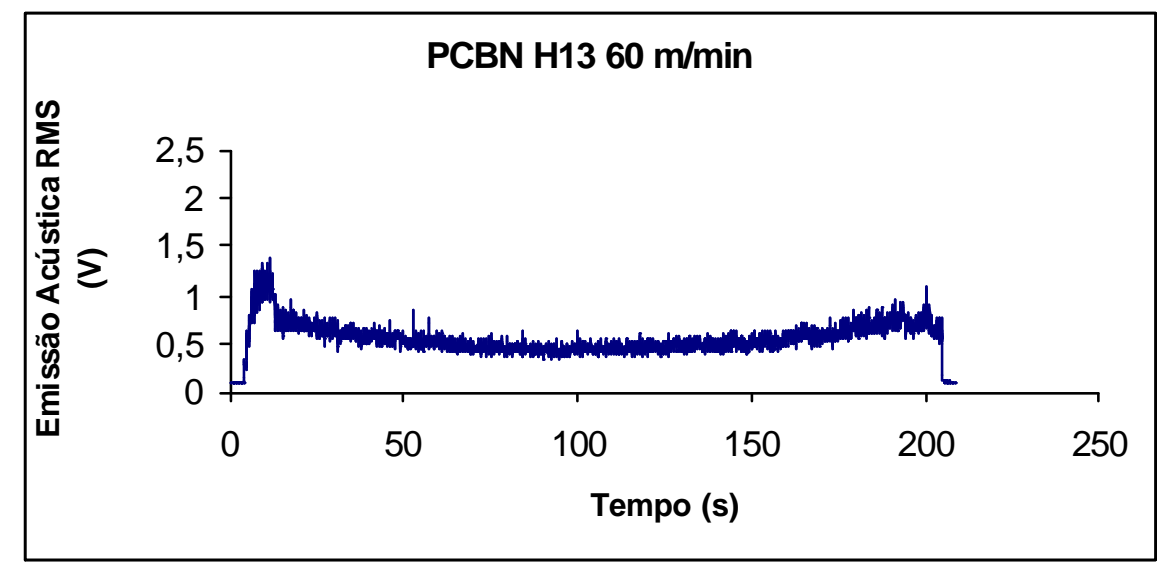

(a) Aço H13.

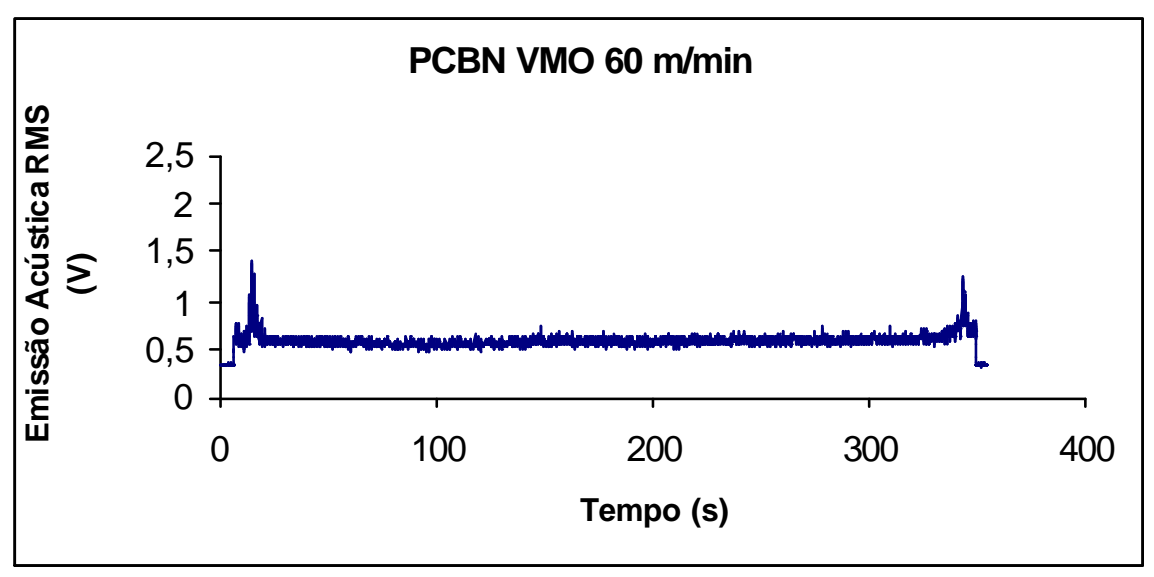

(b) Aço VMO.

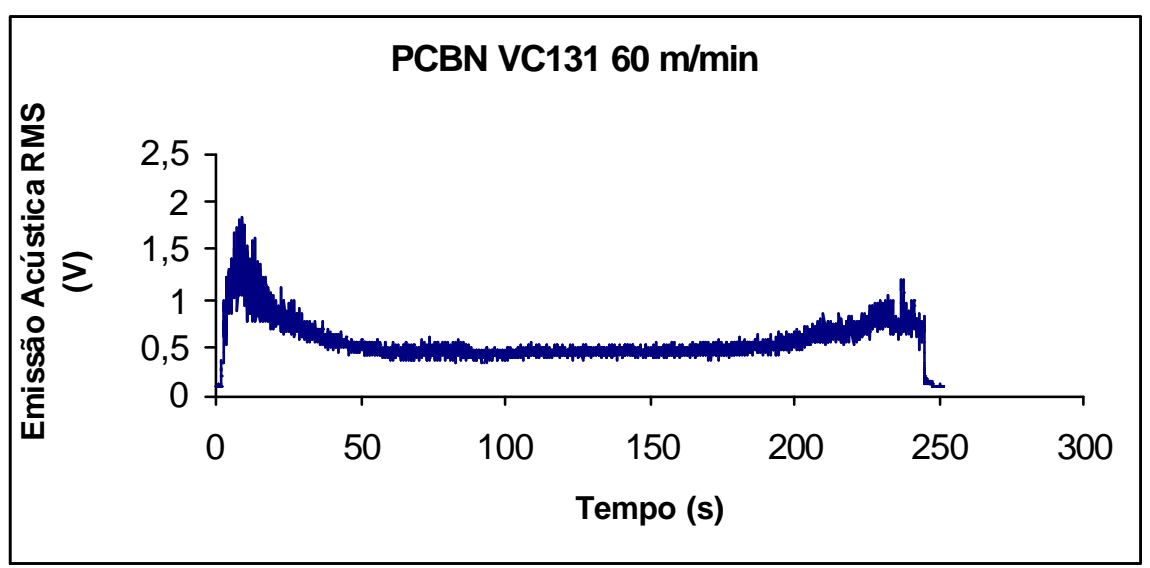

(c) Aço VC131.

Figura 4.23 - Diferentes níveis de emissão acústica, para cada material usinado, com ferramentas de PCBN.

Reunindo os dados de voltagem RMS média da seção 4.4.2 e os dados desta seção pode-se construir a tabela 4.1. Quando analisando a voltagem RMS 
média para cada material de ferramenta, observa-se que ela é maior para o MD em todos os materiais de peça.

Tabela 4.1 - Variação da voltagem RMS média com o material da ferramenta.

\begin{tabular}{|c|c|c|c|}
\hline \multirow{2}{*}{$\begin{array}{c}\text { Material de } \\
\text { Ferramenta }\end{array}$} & H13 & VMO & VC131 \\
\cline { 2 - 4 } & 0,59 & 0,99 & 0,90 \\
\hline MD & 0,56 & 0,59 & 0,57 \\
\hline
\end{tabular}

\subsection{4 - Resumo dos gráficos de emissão acústica}

Através da análise dos gráficos pode-se notar que o valor da voltagem RMS sobe com a velocidade de corte. Segundo a literatura isso se deve ao aumento das deformações plásticas dentro do material (Teti, et al., 1989) (Kannatey-Asibu, et al., 1981).

A emissão acústica varia com o material usinado, sendo o aço VMO o material que geral a maior média de voltagem RMS. Este comportamento possivelmente se deve a composição química de cada material, que forma diferentes combinações de elementos químicos. Estes, por sua vez alteram a tensão de cisalhamento de cada material, conforme constatado por Teti, et al., 1989.

O sinal de emissão acústica também varia com o material da ferramenta, tendo o maior nível as ferramentas de MD. É provável que este comportamento se deva ao fato de a ferramenta de MD ter um coeficiente de atrito alto durante a usinagem e deformar-se mais que a ferramenta de PCBN, assim a ferramenta de MD tem mais dificuldade para deformar o cavaco.

\section{5 - Discussão final}

As ferramentas de PCBN apresentam um desgaste de flanco menor que as ferramentas de MD, independentemente da velocidade de corte $(60,100 \mathrm{~m} / \mathrm{min})$, mostrando ser mais resistentes ao desgaste devido às suas melhores propriedades 
mecânicas e resistência ao desgaste abrasivo e adesivo. Outro fator de influência, que pode ajudar a explicar a diferença de desgaste é a dureza a quente destas ferramentas, cerca de $400 \mathrm{HV}\left(1000^{\circ} \mathrm{C}\right)$ para o $\mathrm{MD}$ e $1800 \mathrm{HV}\left(1000^{\circ} \mathrm{C}\right)$ para o PCBN, tabela 2.4 (Abrão, et al., 1993).

O desgaste de flanco máximo para cada material de ferramenta é cerca de 0,5 mm para o PCBN e 0,75 mm para o $\mathrm{MD}$, ambos quando usinando o aço VC131, na velocidade de $60 \mathrm{~m} / \mathrm{min}$. O VC131 se mostra como o material de maior dificuldade de usinagem pelo fato de ser o único material que, além de martensita, possui carbeto na sua microestrutura (Ohtani, et al., 1988).

Os mecanismos de desgaste predominantes são a adesão e a abrasão. Os dois mecanismos são encontrados em combinação na grande maioria das ferramentas desgastadas, existe apenas uma alternância de intensidade entre os dois mecanismos (Shaw, 1971).

Tanto a adesão quanto a abrasão ocorrem nas ferramentas de PCBN, sendo a última mais comum, aumentando com a velocidade de corte.

Nas ferramentas de MD a abrasão aparece claramente na velocidade de corte mais alta $(180 \mathrm{~m} / \mathrm{min})$. A diferença de resistência à abrasão entre os dois materiais de ferramenta possivelmente é devido à menor dureza do MD. A adesão é dominante nas ferramentas de MD nas velocidade de corte mais baixas (principalmente na velocidade de $60 \mathrm{~m} / \mathrm{min}$ ).

O desgaste dominante é o de flanco em ambas as ferramentas. É um tipo de desgaste caracteristicamente causado pela abrasão entre a superfície de folga ferramenta e a superfície recém usinada. Partículas duras presentes na superfície na peça arrancam material da ferramenta.

Existe indícios de desgaste de cratera nas ferramentas (principalmente de $\mathrm{MD}$ ), o que se deve à interação entre o cavaco e a superfície de saída da ferramenta. Isto pode ser atribuído aos mecanismos de abrasão e adesão.

A rugosidade manteve-se em uma faixa de 0,2 à $0,35 \mu \mathrm{m}$ Ra, independentemente do material da ferramenta, do material da peça e da velocidade de corte. Esta faixa, relativamente estreita, possivelmente deve-se ao avanço constante $(0,02 \mathrm{~mm} /$ dente) $)$ Em uma série de experimento feita com o aço H13 e ferramenta de MD, onde variou-se a velocidade de corte e o avanço, a rugosidade mostra-se dependente do avanço; obteve-se para avanço de 0,05 
$\mathrm{mm} /$ dente valores variando de 0,4 à $0,6 \mu \mathrm{m}$ e para avanço de $0,1 \mathrm{~mm} / \mathrm{dente}$ valores em torno de $0,7 \mathrm{~mm}$. Esta dependência entre rugosidade e avanço confirma dados teóricos encontrados na literatura (Kronenberg, 1966, Ferraresi, 1977).

O sinal de emissão acústica aumenta com a velocidade de corte, devido ao aumento da taxa de deformação plástica durante a usinagem. Este também varia com os materiais usinados e com os materiais de ferramenta. Como os materiais usinados possuem valores diferentes de resistência ao cisalhamento, espera-se níveis diferentes de emissão acústica, (Kannatey-Asibu, et al., 1981). Para as ferramentas de PCBN o nível do sinal de emissão acústica é menor devido, provavelmente, á maior facilidade de formação de cavacos, uma vez que o seu desgaste é menor. Neste caso as fontes geradoras de emissão acústica são de menor intensidade (Teti, et al., 1989).

Todos os gráficos de emissão acústica possuem picos no início e no fim do gráfico; isto se deve, no início, ao aumento de material que a ferramenta remove em cada volta e no final quando a ferramenta está terminando o rasgo a mesma dá dois golpes no material ao invés de um.

A comparação do volume de material removido entre as ferramentas de PCBN e MD pode ajudar na avaliação do desempenho. A figura 4.24 mostra esta comparação para cada material usinado na velocidade de corte de $60 \mathrm{~m} / \mathrm{min}$.

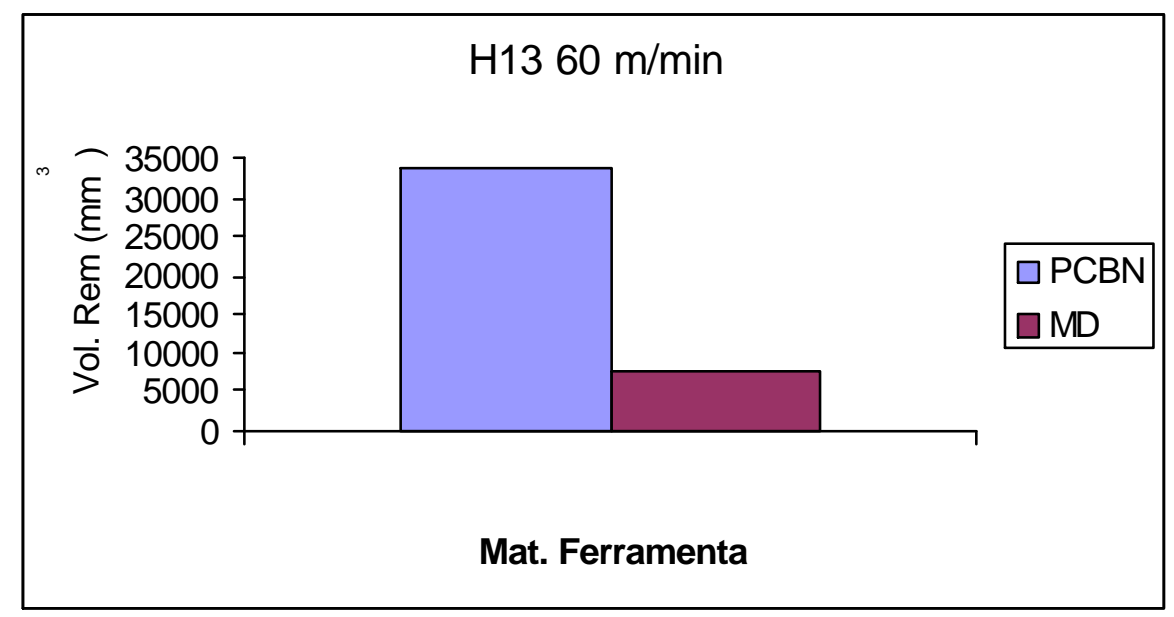

(a) Para o aço H13 a diferença de volume de material removido foi de 4,5 vezes. 


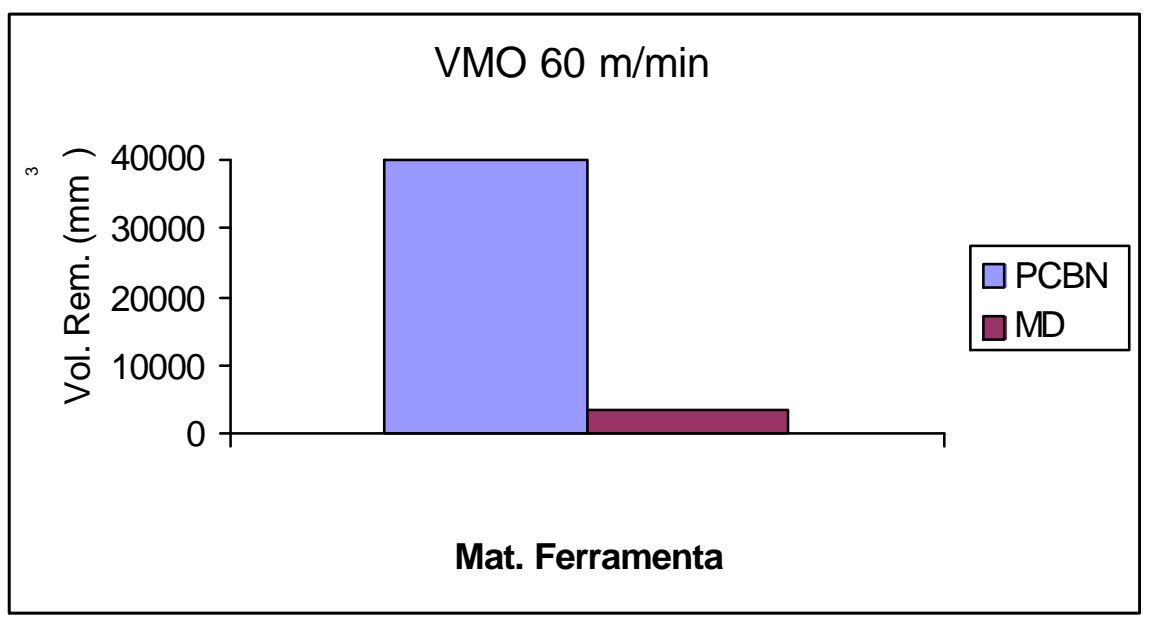

(b) Para o aço VMO a diferença de volume de material removido foi de 11 vezes.

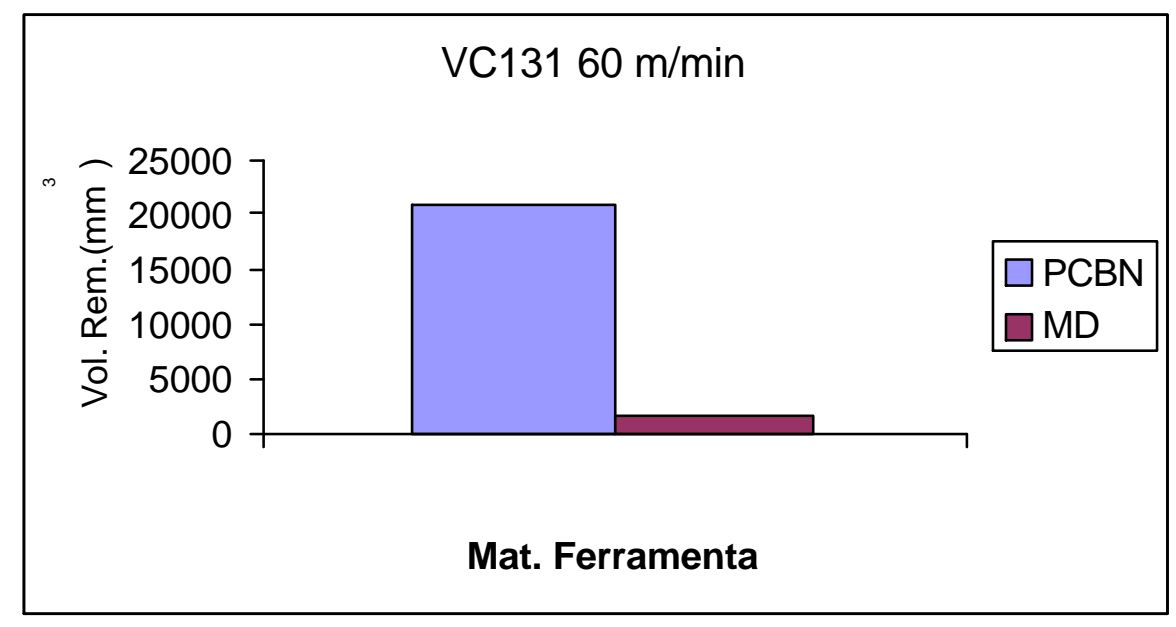

(c) Para o aço VC131 a diferença de volume de material removido foi de 11,6 vezes.

Figura 4.24 - Comparação de volume de material removido para as ferramentas de PCBN e MD.

Uma comparação semelhante pode ser feita com relação ao custo das ferramentas por centímetro cúbico usinado. De acordo com a figura 4.25 o menor custo para a ferramenta de MD é na usinagem do aço H13, 0,76 R $\$ / \mathrm{cm}^{3}$, sendo o preço de cada aresta $\mathrm{R} \$ 5,75$. Para a ferramenta de PCBN este valor é $2,00 \mathrm{R} \$ / \mathrm{cm}^{3}$ na usinagem do aço $\mathrm{VMO}$, sendo o preço de cada aresta $\mathrm{R} \$ 80,00$. De um modo geral o custo de uma ferramenta de PCBN é maior. Por outro lado a ferramenta de MD tem o inconveniente de ter uma vida muito menor; a substituição da aresta de corte torna-se obrigatória em um curto espaço de tempo, além do fato de que a ferramenta de PCBN pode manter a precisão dimensional com maior facilidade. 


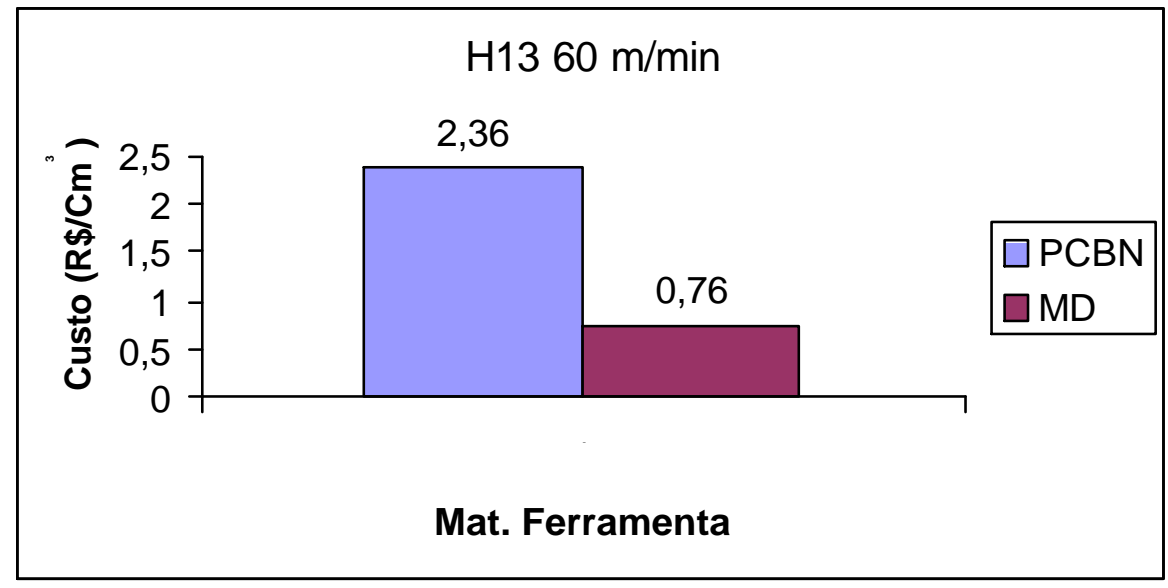

(a) Custo na usinagem do aço $\mathrm{H} 13$.

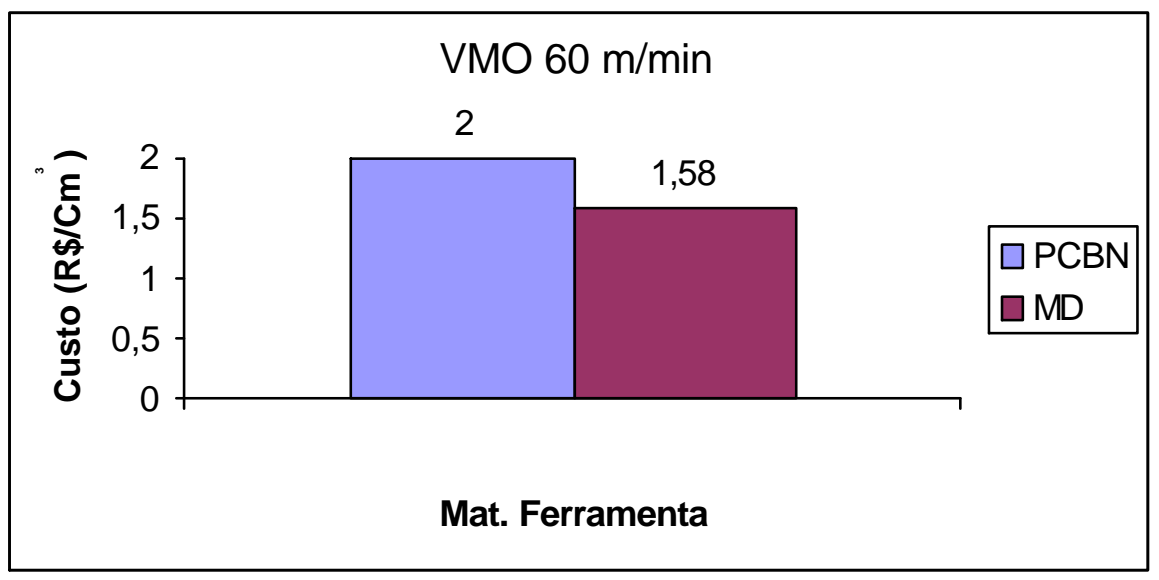

(b) Custo na usinagem do aço VMO.

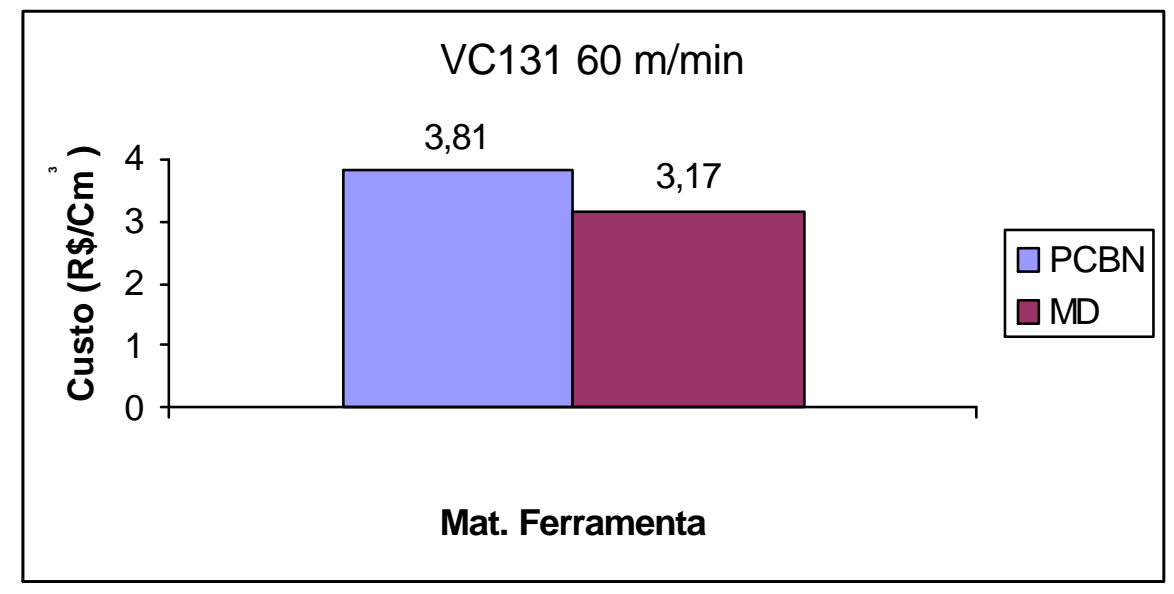

(c) Custo na usinagem do aço VC131.

Figura 4.25 - Custo de usinagem para cada material usinado por ferramenta de corte. 


\section{0 - CONCLUSÕES}

A partir da análise dos resultados obtidos nos ensaios de fresamento de topo e, com base na literatura técnica revisada, neste trabalho pode-se concluir que:

- As ferramentas de PCBN apresentam um desgaste muito menor que as ferramentas de MD. Seu uso em operações de acabamento, onde o volume removido é mínimo, pode ser viável usando-se as condições de corte adequadas, uma vez que o valor do desgaste é função da velocidade de corte, do material da peça e do material da ferramenta.

- A rugosidade superficial aumenta com o avanço por dente e, apresenta as seguintes faixas de valores para as duas ferramentas: 0,2 à 0,35 $\mu \mathrm{m}$ Ra para um avanço de $0,02 \mathrm{~mm} /$ dente, 0,4 à 0,6 para $0,5 \mathrm{~mm} /$ dente e de 0,7 à 0,8 para $0,1 \mathrm{~mm} /$ dente.

- A análise de fotografias de microscopia eletrônica mostra indícios de que o mecanismo de desgaste atuante é uma combinação de adesão com abrasão.

- A análise das fotografias de microscopia eletrônica indicam o predomínio de desgaste de flanco e indícios de desgaste de cratera.

- Micrografias não revelaram evidências de trincas na camada abaixo da superfície usinada. Camadas alteradas foram observadas, provavelmente devido a alterações na microestrutura causadas pela usinagem.

- O nível médio RMS da emissão acústica aumenta com a velocidade de corte. Observa-se também que depende do material da peça e da ferramenta. Menores níveis forma observados para as ferramentas de PCBN. 


\section{0 - SUGESTÕES PARA TRABALHOS FUTUROS}

Com base nos experimentos realizados, pode-se fazer algumas sugestões para trabalhos futuros, sobre pontos que devem ser melhor investigados para o aprofundamento do conhecimento do fresamento de topo em materiais endurecidos:

- Refazer os ensaios para as ferramentas de PCBN com velocidades de corte superiores às utilizadas $(180 \mathrm{~m} / \mathrm{min})$. Há trabalhos em andamento no momento que exploram velocidades de corte da ordem de $500 \mathrm{~m} / \mathrm{min}$.

- Utilizar ferramentas de PCBN com maior quantidade de CBN.

- Utilizar ferramentas de PCBN com geometria de aresta diferente, por exemplo, com maior ângulo de chanfro e aresta com "honing". 


\section{0 - BIBLIOGRAFIA}

ABRAHAM, T. (1995). Growth continues for diamond, DLC and CBN markets. Journal of Metals, v. 47, n. 11, p. 60, Nov.

ABRÃO, A M.; ASPINWALL, D.K.; WISE, M. L. H. (1993). A review of polycrystalline cubic boron nitride cutting tool developments and aplication. In: MATADOR CONFERENCE, 30, Manchester,1993. Proceeding. Manchester, University of Manchester Institute of Science and Technology Department of Mechanical Engineering, p. 169 - 180.

ABRÃO, A. M.; ASPINWALL, D. K. (1997). Tool life of PCBN and Ceramic cutting tools when turning hardned AISI E52100 steel. (CD ROM). In: CONGRESSO BRASILEIRO DE ENGENHARIA MECÂNICA, 14., Bauru. Anais. Bauru, ABCM. Cód. COB146.

AMERICAN SOCIETY FOR METALS. (1984). Metals Handbook. Desk ed. Metals Park, Ohio. p. 27.3 - 27.14.

ASPINWAL, D. K.; CHEN, W. (1987). Report on CBN tooling aplications in machining of iron. University of Birmingham. apud Rai, G. p 504.

ASSOCIAÇÃO BRASILEIRA DE NORMAS TÉCNICAS. (1989). NBR 6162 Movimentos e relações geométricas na usinagem dos metais. Rio de Janeiro.

BAUMGARTEN, J. F. (1988). Aplicação e desenvolvimento da cerâmica avançada. Máquinas e Metais, n. 265, p. 51 - 56, jan. - fev. 
BAYER, A. M.; BECHERER, B. A. (1989). High-speed tool steels. In: AMERICAN SOCIETY FOR METALS. Metals Handbook. 9. ed. Metals Park, Ohio. v.16, p. $51-59$.

COELHO, R. T. (1994). The machinability of aluminium - based SiC reinforced Metal Matrix Composite (MMC) alloy whith emphasis on hole production. Birmingham. 327p. Thesis (PHD) - School of Manufacturing and Mechanical Engineering, University of Birmingham.

CUPINI, N. L.; FERREIRA, J. R. (1993). Turning of carbon and glass fiber hybrid cloth composite material. NIST - Special Publication, n. 847, p. 447 453, June.

DAVIES, M. A.; CHOU, Y.; EVANS, C.J. (1996). On chip morphology, tool wear and cutting mechanics in finish hard turning. CIRP Annals, v. 45, n. 1,p. $77-82$.

DEGARMO, E. P.; BLACK, J. T.; KOHSER, R. A. (1997). Materials and processes in manufacturing. 8. ed. Upper Saddle River, NJ, Prentice Hall.

DEVRIES, R. C. (1972). Cubic boron nitrede: handbook of properties. Schenectady, General Electric Company. (Technical Information Series Physical Chemistry Laboratory, n. 72CRD178).

DIXON, G.; WRIGHT, R. N. (1985). Processes involved in the wear of cemented carbide tools. Wear, v. 104, p. 157 - 171.

EL-BESTAWI, M. A.; EL-WARDANY; T. I.,YAN, D.; TAN, M. (1993). Performance of whisker-reinforced ceramic tools in milling nickel-based superalloy. CIRP Annals, v. 42, n. 1, p. 99 - 102. 
EVANS, A. G.; MARSHALL, D. B. (1980). Wear mechanisms in ceramics. Fundamental of friction and wear of materials, ed. by Rigney ASM, Metals Park, Ohio, p. 439 - 452. apud GUEROULT, B.; CHERIF, K. p.135.

FERRARESI, D. (1977). Fundamentos da usinagem dos metais. São Paulo, Edgard Blücher.

GRUSS, W. W. (1989). Cermets. In: AMERICAN SOCIETY FOR METALS. Metals Handbook. 9. ed. Metals Park, Ohio. v.16, p. 90 - 104.

GUEROULT, B.; CHERIF, K. (1994). State of the art review on friction and wear mechanisms of ceramics. Journal of the Canadian Ceramic Society, v. 63, n. 2, p. 132 - 142, May.

HEATH, P. J. (1989). Ultrahard tool materials. In: AMERICAN SOCIETY FOR METALS. Metals Handbook. 9. ed. Metals Park, Ohio. v.16, p. 105 - 117.

HINTERMANN, H. E.; CHATTOPADHYAY, A. K. (1993). Low pressure synthesis of diamond coatings. CIRP Annals, v.42, n. 2, p. 769 - 783.

KALISH, H. S. (1983). Status report: cutting tool materials. Metal Progress, v. 124, n. 6, p. 21 - 27, Nov.

KANEEDA, T.; TSUWA, H. (1979). Detecting fracture phenomena in separation process at tool tip in metal cutting by acoustic emission technique. Bulletin Japan Society of Precision Engineering, v. 13, n. 3, p. 159 - 160, Sept.

KANNATEY-ASIBU,E.; DORNFELD, D. A. (1981). Quantitative relationships for acoustic emission from orthogonal metal cutting. Journal of Engineering for Industry, v. 103, p. 330 - 340, Aug. 
KENDALL, L. A. (1989). Toll wear and tool life. In: AMERICAN SOCIETY FOR METALS. Metals Handbook. 9. ed. Metals Park, Ohio. v.16, p. 37 48.

KLIMENKO, S. A.; MUKOVOZ, Y. A.; LYASHKO, V. A.; VASHCHENKO, A. N.; OGORODNIK, V. V. (1992). On the wear mechanism of cubic boron nitride base cutting tools. Wear, v. 157,n. 1 , p. 1 - 7, Aug.

KOMANDURI, R.; SAMANTA, S. K. (1989). Ceramics. In: AMERICAN SOCIETY FOR METALS. Metals Handbook. 9. ed. Metals Park, Ohio. v.16, p. $98-104$.

KÖNIG,W.; NEISES, A. (1993). Wear mechanisms of ultrahard, non-metallic cutting materials. Wear, v. 162 - 164, p. 12 - 21.

KRONENBERG, M. (1966). Machining science and application. London, Pergamon Press.

LIM, S. C.; LIM, C. Y. H.; LEE, K. S. (1995). The effects of machining conditions on the flank wear of TiN-coated high speed steel tool inserts. Wear, v.181-183, n. 2, p. 901 - 912, Mar.

LIN, Z. C.; CHEN, D. Y. (1995). A study of cutting with a CBN tool. Journal of Materials Processing Technology, v. 49, n. 1 - 2, p. 149 - 164, Feb.

LO CASTO, S.; LO VALVO, E.; RUISI, V. F.; LUCCHINI, E.; MASCHIO, S. (1993). Wear mechanism of ceramic tools. Wear, v. 160, n. 2, p. $227-235$, Feb.

MACHADO, Á. R. (1988). A evolução dos materiais para ferramentas de corte. Máquinas e Metais, n. 265 , p. 92 - 97, jan. fev. 
MASUDA, M.; SATO, T.; KORI, T.; CHUJO, Y. (1994). Cutting performance and wear mechanism of alumina-based ceramic tools when machining austempered ductile iron. Wear, v. 174, n 1-2, p. 147 - 153, May.

McGRAW, C.; WILSHIRE, B. (1997). Applications and advancements in cermet cutting tools. Machining Technology, v. 8, n. 4, p. 1 - 5 .

Modern metal cutting.- a practical handbook. (1994). Sandviken, Tofters Tryckeri AB.

NARUTAKI, N.; YAMANE, Y.; HAYASHI, K.; KITAGAWA, T. (1993). Highspeed machining of Inconel 718 with ceramic tools. CIRP Annals, v. 42, n. 1, p. 103 - 106.

OHTANI, T.; YOKOGAWA, H. (1988). The effects of workpiece hardness on tool wear characteristics. Bulletin os the Japan Society of Precision Engineering, v. 22, n. 3, p. 229 - 231, Sept.

OOMEN, J. M.; EISSES, J.(1992). Wear of monocrystalline diamond tools during ultraprecision machining of nonferrous metals. International Jornal of the American Society for Precision Engineering,v. 14, n. 4, p. 206 - 218, Oct.

PAN, C. S.; DORNFELD, D. A. (1986). Modeling the diamond turning process with acoustic emission for monitoring applications. Proc. $14^{\text {th }}$ NAMRC, University of Minneapolis, May, p. 257 - 265. Apud TETI, R.; DORNFELD, D. A. p. 234.

PASHBY, I. R.; WALLBANK, J.; BOUD, F. (1993). Ceramic tool wear when machining austempered ductile iron. Wear, v. 162-164, pt. A, p. 22 - 33, Apr.

QI, H. S.; MILLS, B. (1996). On the formation mechanism of adherent layers on a cutting tool. Wear, v. 198, n. 1-2, p. 192 - 196, Oct. 
RAI, G. (1993). Metallurgy of CBN and its wear in high speed machining of ferrous materials. NIST - Special Publication, n. 847, p. 501 - 506, June.

RANGWALA, S.; DORNFELD, D. A. (1991). A study of acoustic emission generated during orthogonal metal cutting-2: spectral analysis. International Journal of Mechanical Science, v. 33, n. 6, p. $489-499$.

RIGAUT, B.; CHEN, Y. M.; SAINT CHELY, J. (1994). Wear behavior of $\mathrm{Al}_{2} \mathrm{O}_{3}$, $\mathrm{Si}_{3} \mathrm{~N}_{4}$ and $\mathrm{CBN}$ cutting tool materials at high sliding speed. Lubrication Engineering, v. 50, n. 6, p. 485 - 489, June.

SANTHANAM, A. T.; TIERNEY, P. (1989). Cemented carbides. In: AMERICAN SOCIETY FOR METALS. Metals Handbook. 9. ed. Metals Park, Ohio. v.16, p. 71 - 89.

SASAKI, K.; TAKATSU, S.; SHIBUKI, K.; FUKAWA. (1982). Development and cutting performance of CVD coated cemented carbides for milling. R\&HM, p. 157 - 160, Dec.

SHAW, M. C. (1971). Fundamentals os wear. CIRP Annals, v. 29, p. 533 - 543.

SHAW, M. C. (1986). Metal cutting principles. Oxford. Oxford University Press.

SHINTANI, K.; UEKI, M.; FUJIMURA, Y. (1989). Optimum cutting tool geometry when interrupted cutting carburized steel by CBN toll. International Journal of Machine Tools \& Manufacture, v. 29, n. 3, p. $415-423$.

SHINTANI, K.; UEKI, M.; FUJIMURA, Y. (1989). Optimum tool geometry of CBN toll for continuous turning of carburized steel. International Journal of Machine Tools \& Manufacture, v. 29, n. 3, p. 403 - 413. 
SILVA, R. P.; ABRÃO, A. M.; SALES, W. F.; MACHADO, A. R. (1997). Usinabilidade de aços temperados em operações de fresamento utilizando ferramentas cerâmicas. In: CONGRESO INTERNACIONAL DE INGENIERIA MECÁNICA 97, Havana. Anales. Havana, 1997. Cód. 4.203.

STEINMETZ, K.; SANTNER, E.; GRENAU, M.; SCHWENZIEN, J. (1993). Friction \& wear behaviour of syndite PCD. Industrial Diamond Review, v. 53, n. 554, p. 19 - 24, Jan.

TAKATSU, S. (1990). Recent developments in hard cutting tool materials. High Temperature Materials and Processes, v. 9, n. 2-4, p. 175 - 193.

TETI, R.; DORNFELD, D. A. (1989). Modeling and experimental analysis of acoustic emission from metal cutting. Journal of Engineering for Industry, v. 111 , p. $229-237$, Aug.

THOORS, H.; CHANDRASEKARAN, H.; ÖLUND, P. (1993). Study of some active wear mechanisms in a titanium-besed cermet when machining steels. Wear, v. 162-164, pt. A, p. 1 - 11, Apr.

TÖNSHOFF, H. K.; WOBKER, H. G.; BRANDT, D. (1995). Tribological aspects of hard turning with ceramic tools. Lubrication Engineering, v. 51, n. 2, p. 163 - 168, Feb.

TÖNSHOFF, H. K.; WOBKER, H. G.; CASSEL, C. (1994). Wear characteristics of cermet cutting tools. CIRP Annals, v. 43, n. 1, p. 89 - 92.

TRAVA-AIROLDI, V. J.; CORAT, E. J.; BARANAUSKAS, V. (1994). Diamante CVD: recentes pesquisas e densevolvimentos no mundo e no país. In: CONGRESSO BRASILEIRO DE ENGENHARIA E CIÊNCIA DOS MATERIAIS, 11., Águas de São Pedro. Anais. s. 1. , s. ed. , 1994. v. 1, p.603 -609 . 
TRENT, E.M. (1984). Metal cutting. 2. ed. London, Butterworths.

TRIPPE, S. C.; MAMMANA, V. P.; ALMEIDA, A. P.; SALVADORI, M. C. (1994). Síntese de filmes de diamante. In: CONGRESSO BRASILEIRO DE ENGENHARIA E CIÊNCIA DOS MATERIAIS, 11., Águas de São Pedro. Anais. s. 1. , s. ed. , 1994. v. 1, p.611 - 614.

VLEUGELS, J.; JACOBS, P.; KRUTH, J. P.; VANHERCK, P.; DU MONG, W.; VAN DER BIEST, O. (1995). Machining of steel with sialon ceramics: influence of ceramic and workpiece composition on tool wear. Wear, v.189, n. $1-2$, p. 32 - 44, Oct.

XIAO, H. (1990). Wear behaviour and wear mechanism of ceramic tools in machining hardened alloy steel. Wear, v. 139, n. 2, p. 439 - 451, Aug.

YAMAMOTO, T.; OLSSON, M.; HOGMARK, S. (1994). Three-body abrasive wear of ceramic materials. Wear, v. 174, n. 1-2, p. 21 - 31, May. 


\section{APÊNDICE I}

Programa de usinagem utilizado nos experimentos.

$\% 40$

N5 G90

N10 G54

N15 G95 D12

N20 M03 S4775

N25 G00 X-15.0 Y-7.0 Z5.0

N30 G01 Z-1.0 F0.02

N35 G01 X100.0

N40 G01 Z5.0

N45 G00 X-15.0 Y 50.0

N50 M05 


\section{APÊNDICE II}

Tela do software de aquisição de dados.

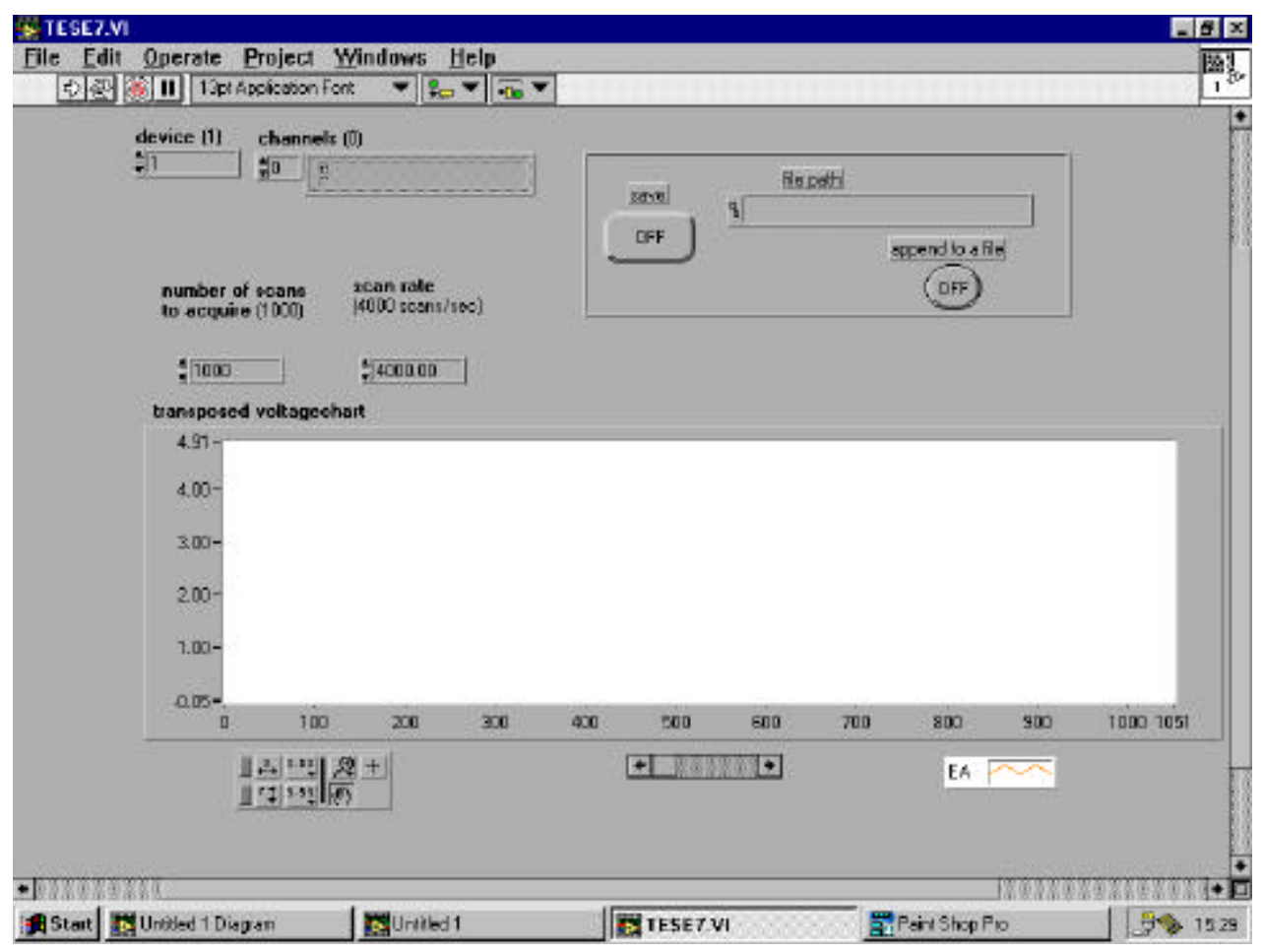

Diagrama interno do programa de aquisição.

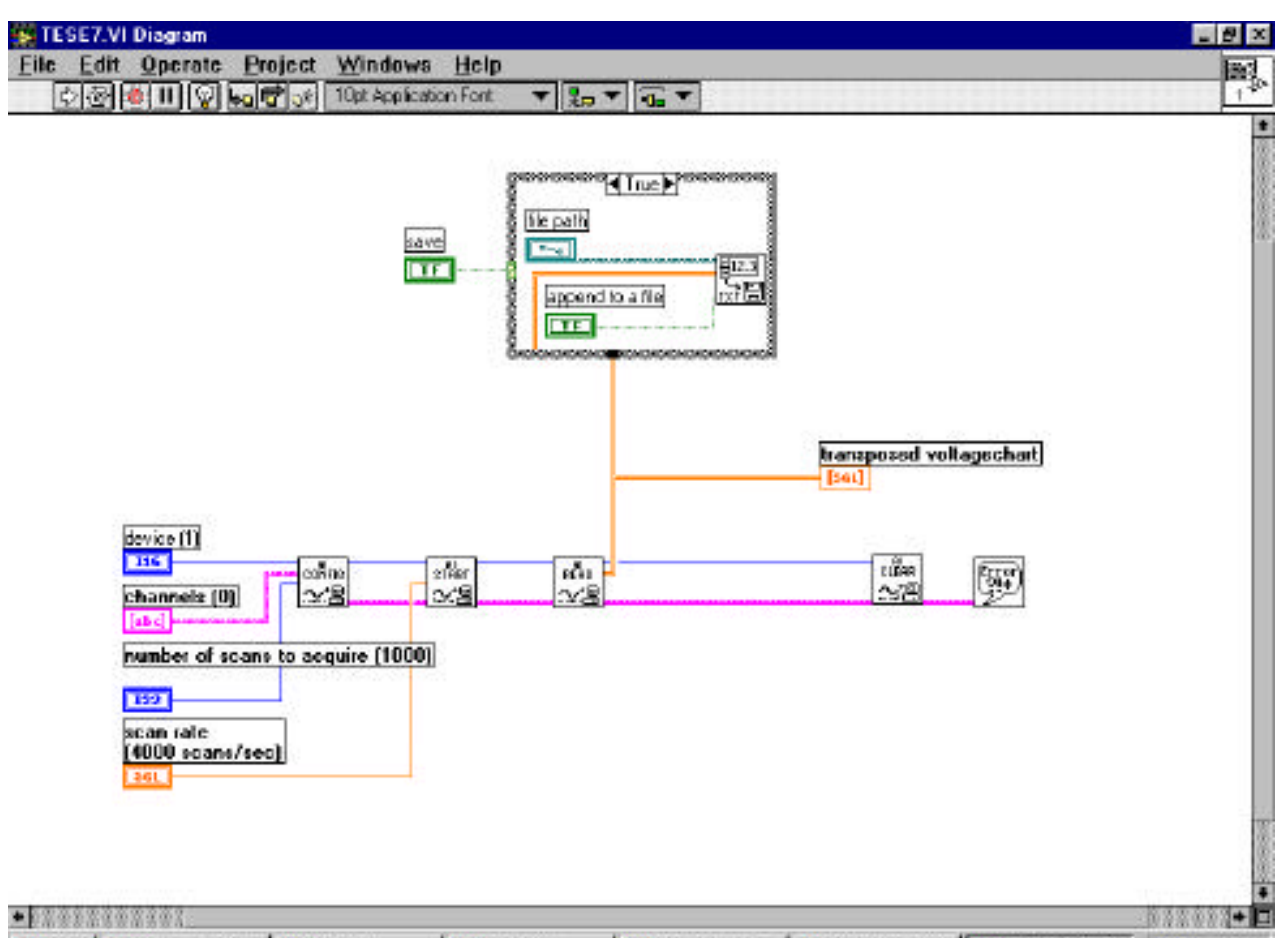

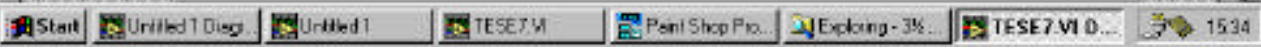

